\title{
REVIEW
}

\section{Particle capture mechanisms in suspension-feeding invertebrates}

\author{
Hans Ulrik Riisgård ${ }^{1, *}$, Poul S. Larsen ${ }^{2}$ \\ ${ }^{1}$ Marine Biological Research Centre (University of Southern Denmark), Hindsholmvej 11, 5300 Kerteminde, Denmark \\ ${ }^{2}$ DTU Mechanical Engineering, Fluid Mechanics, Technical University of Denmark, Building 403, 2800 Kgs. Lyngby, Denmark
}

\begin{abstract}
A large number of suspension-feeding aquatic animals (e.g. bivalves, polychaetes, ascidians, bryozoans, crustaceans, sponges, echinoderms, cnidarians) have specialized in grazing on not only the 2 to $200 \mu \mathrm{m}$ phytoplankton but frequently also the 0.5 to $2 \mu \mathrm{m}$ free-living bacteria, or they have specialized in capturing larger prey, e.g. zooplankton organisms. We review the different particle capture mechanisms in order to illustrate the many solutions to the common problem of obtaining nourishment from a dilute suspension of microscopic food particles. Despite the many differences in morphology and living conditions, particle capture mechanisms may be divided into 2 main types. (1) Filtering or sieving (e.g. through mucus nets, stiff cilia, filter setae), which is found in passive suspension feeders that rely on external currents to bring suspended particles to the filter, and in active suspension feeders that themselves produce a feeding flow by a variety of pump systems. Here the inventiveness of nature does not lie in the capture mechanism but in the type of pump system and filter pore-size. (2) A paddle-like flow manipulating system (e.g. cilia, cirri, tentacles, hair-bearing appendages) that acts to redirect an approaching suspended particle, often along with a surrounding 'fluid parcel', to a strategic location for arrest or further transport. Examples include (1) sieving (e.g. by microvilli in sponge choanocytes, mucus nets in polychaetes, acidians, and salps among others), filter setae in crustaceans, 'ciliary sieving' by stiff laterofrontal cilia in bryozoans and phoronids; and (2) 'cirri trapping' in mussels and other bivalves with eu-laterofrontal cirri, ciliary 'catch-up' in bivalve and gastropod veliger larvae, some polychaetes, entroprocts, and cycliophores. These capture mechanisms may involve contact with a particle, and possibly mechanoreception or chemoreception, or may include redirection of particles by the interaction of multiple currents (e.g. in scallops and other bivalves without eu-laterofrontal cirri). Based on the review, we discuss the current physical and biological understanding of the capture process and suggest a number of specific problems related to particle capture, which may be solved in the future using advanced theoretical, computational and experimental techniques.
\end{abstract}

KEY WORDS: Suspension feeding $\cdot$ Particle retention $\cdot$ Adaptation to the environment $\cdot$ Design of filter-pumps $\cdot$ Sieving $\cdot$ Aerosol theory

\section{INTRODUCTION}

Suspension-feeding animals are necessary links between the suspended phytoplankton and higher trophic levels in aquatic food chains. Considering the dominant role of phytoplankton in the primary production in the sea, it is understandable that suspension feeding is widespread, and suspension feeders are found in almost all animal classes represented in the marine environment-such as sponges, bivalves, polychaetes, ascidians, bryozoans, crustaceans, and cnidarians and ctenophores (Jørgensen 1966, 1975a, Riisgård \& Larsen 1995, 2000, 2001, see also summaries by Strathmann 1987 and Wotton 1994). Suspen- 
sion feeders have specialized in grazing on phytoplankton or predation on e.g. small zooplankton organisms by evolving different mechanisms for particle retention to solve the same basic problem of extracting a sufficient amount of food from a dilute environment.

Not only large phytoplankton — such as diatoms and dinoflagellates - and zooplankton serve as food for pelagic and benthic suspension feeders, but also tiny phytoplankton (2 to $20 \mu \mathrm{m}$ ) and even smaller free-living bacteria $(0.5$ to $2 \mu \mathrm{m})$ serve as food for many suspension-feeding invertebrates. In this way, many suspension feeders are not only important grazers in the classic food chain, but they also act as links to the microbial loop (Fenchel 2008). Although evolution has led to many different types of particle capture mechanisms, a large number of resemblances between otherwise distantly related species of suspension feeders is found, likely dictated by the physical laws that are necessary to comply with for successful survival (Rubenstein \& Koehl 1977, LaBarbera 1984, Shimeta \& Jumars 1991, Vanderploeg 1994, Humphries 2007).

Our main concern in this review is the various mechanisms used by suspension-feeding animals to capture suspended food particles and prey. The transport of captured particles to the mouth and possible sorting mechanisms are not treated. Many suspension-feeding animal groups are found in both marine and freshwater habitats (e.g. sponges, bivalves, copepods, cladocerans), and the examples used in the present account broadly cover the aquatic environment, although suspension-feeding insects, which are restricted to freshwater habitats, are not treated.

In the following sections, we present several different types of particle capture mechanisms found in benthic suspension-feeders as well as in several pelagic mero- and holoplanktonic zooplankton organisms. Detailed examples from each type of mechanism illustrate the different solutions and, based on this review, we discuss essential physical and biological aspects of the current understanding of particle capture mechanisms.

\section{CAPTURE MECHANISMS}

In this review the following food-particle capture mechanisms are treated: (1) collar sieving in sponges, where a beating flagellum creates a feeding current through a collar filter; (2) cirri trapping in bivalves with gill spaces possessing laterofrontal cirri that beat against the through-current, supplemented with a comparison to those bivalves that only possess prolateralfrontral cilia; (3) ciliary sieving in bryozoans, phoronids, and brachiopods, where particles are re- tained by a filter formed by a band of stiff cilia upstream of the water-pumping lateral cilia; (4) ciliary downstream collecting in a diverse group of suspension-feeding invertebrates, where food particles are caught-up by compound cilia (that also create the current) and are then transferred to the downstream side for collection; (5) mucus-net filter-feeding in some species of polychaete worms, gastropods, ascidians, salps, appendicularians and lancelets, where ciliary or muscular pumps drive water through a mucus net which retains the suspended food particles; (6) setal filterfeeding in crustaceans; (7) non-filtering ciliary-feeding mechanism in the planktonic larvae of echinoderms; (8) ciliary-spike suspension-feeding in a passive suspension-feeding polychaete; (9) tube-feet suspensionfeeding in echinoderms; (10) cnidae prey-capture mechanisms in jellyfish and antozoans using 'needle cells'; and (11) colloblast prey-capture mechanisms in ctenophores. Among suspension feeders, the term 'filter feeder' is appropriate for those employing actual filter structures (e.g. mucus nets, setae, rakes).

\section{Collar sieving}

Collar sieving is found in sponges. The basic element for both pumping and filtering is the choanocyte with a flagellum that pumps water through a collar of microvilli (diameter $0.1 \mu \mathrm{m}$ and spacing 0.3 to $0.4 \mu \mathrm{m}$ ) acting as a sieve that captures free-living bacteria and other particles down to $\sim 0.1 \mu \mathrm{m}$ diameter (Bidder 1923, Fjerdingstad 1961a,b, Reiswig 1971, 1975, Bergquist 1978, Jørgensen 1983, Simpson 1984, Riisgård et al. 1993, Larsen \& Riisgård 1994, Thomassen \& Riisgård 1995, Wyeth 1999, Leys \& Eerkes-Medrano 2006). The structure of the choanocyte is the same in all sponges andamong the metazoa - sponges are unique in feeding by means of choanocytes. Choanocytes are structurally and functionally identical to the choanoflagellates (Fjerdingstad 1961a,b, Laval 1971, Hibberd 1975), a group of flagellate protozoans that filter free-living bacteria from the water (Fenchel 1982). The striking similarity between choanoflagellates and choanocytes has lead to the assumption that sponges have evolved from choanoflagellates. One crucial difference between sponges and choanoflagellates is the ability of the former to feed also on phytoplankton, which is retained, phagocytosed and digested in the extensive inhalant channel system before the water is finally filtered through the collar slits of the choanocytes. The basic principles for water pumping and particle retention are the same in all sponges. In general, water enters the body of the sponge through numerous small openings (ostia) on the surface, flows through a branched inhalant canal system to the water pumping units - the choanocyte chamber - within which there are numerous choanocytes, 
each with a beating flagellum and a collar filter which efficiently retains small suspended particles, including free living bacteria, and colloidal organic matter (Figs. 1 \& 2) (Reiswig 1975, Bergquist 1978, Frost 1978, Jørgensen 1983, Simpson 1984). The filtered water leaves the choanocyte chamber through an opening to the exhalant canal system that merges into one or more openings (oscula) on the surface. Larsen \& Riisgård (1994) analysed the sponge pump and concluded that the basic pump units in demosponges are the choanocyte chambers which constitute 30 to $50 \%$ of the wall structure separating inhalant and exhalant canals, and furthermore, that all pump units operate in parallel and at essentially the same flow and pressure rise. In this way, large sponges have evolved to become effective filter feeders with a near $100 \%$ retention of particles down to $0.1 \mu \mathrm{m}$ diameter.

\section{Suspension-feeding bivalves}

Bands of lateral cilia produce the main water transport through interfilamentary canals of the gill and 2 different principles are used for capture, depending on the presence or absence of laterofrontal cirri.

\section{Cirri trapping}

The cirri-trapping principle operates in suspensionfeeding bivalves with laterofrontal cirri. Near the entrance to the canals, particles are separated from the main currents and transferred onto the frontal surface by the action of the laterofrontal cirri, which have a fixed, alternating beat pattern (Figs. 3 to 5). Riisgård et al. (1996) report that food particles carried with the through-current are stopped for a while at the entrance to the interfilament gap. Then the path is reversed $180^{\circ}$ and the particles are transferred to the frontal side of the gill filament to be transported towards the marginal food groove by frontal cilia. The transfer of particles is accomplished by the compound laterofrontal cirri (e.g. Silverman et al. 1999), or by the water currents they generate as they beat against the current through an angle of $90^{\circ}$. Particles $>4 \mu \mathrm{m}$ are stopped and transferred to the frontal side, whereas smaller particles either follow the flow around the cirri or they are stopped by the cirri's branching cilia (Dral 1967, Moore 1971, Owen 1974, Jørgensen 1975b, 1990, 1996, Owen \& McCrae 1976, Silvester \& Sleigh 1984, Riisgård 1988, Beninger et al. 1992, Nielsen et al. 1993, Riisgård et al. 1996, Silverman et al. 1999). Although a mechanism based on a low particle-approach angle and direct interception at gill filaments has been proposed (Ward 1996, Ward et al. 1998, 2000), this does not appear consistent with the principles of fluid dyamics (Beninger 2000, Riisgård \& Larsen 2000, Silverman et al. 2000). Based on estimates of pressure drop for flow through a laterofrontal-cirri screen (modeled as parallel cylinders of diameter $0.06 \mu \mathrm{m}$ and spacing $1.3 \mu \mathrm{m})$ and creeping flow calculations, Riisgård et al. (1996) found it plausible that during normal beating
Fig. 1. (a) Schematic outline of advanced sponge design (leucon-type) with a tapered inhalant (IC) and exhalant (EC) canal structure for a single-stage choanocyte chamber CC-pump-canal system with a number of basic pump units in parallel and same pressure rise and flow, i.e. each pump unit handles the same volume flow and yields the same pressure rise. The ECs empty into the atria cavity (AC) and $s$ and $D$ are the inhalant and exhalant canal diameter, respectively. (b) CC separating inhalant canals (IC) and exhalant canals (EC); arrows indicate the direction of water flow through the prosopyles $(\mathrm{P})$ into the $\mathrm{CC}$ and exiting through the apopyle (AP) surrounded by a cone cell (C). The CC is immersed in elastic mesohyl (M) encircled by pinacocyte cells (PC). (c) Two choanocytes with parallel flagella acting as a peristaltic pump. (d) Cross section of flagellum showing projecting ridges. From Larsen \& Riisgård (1994) 


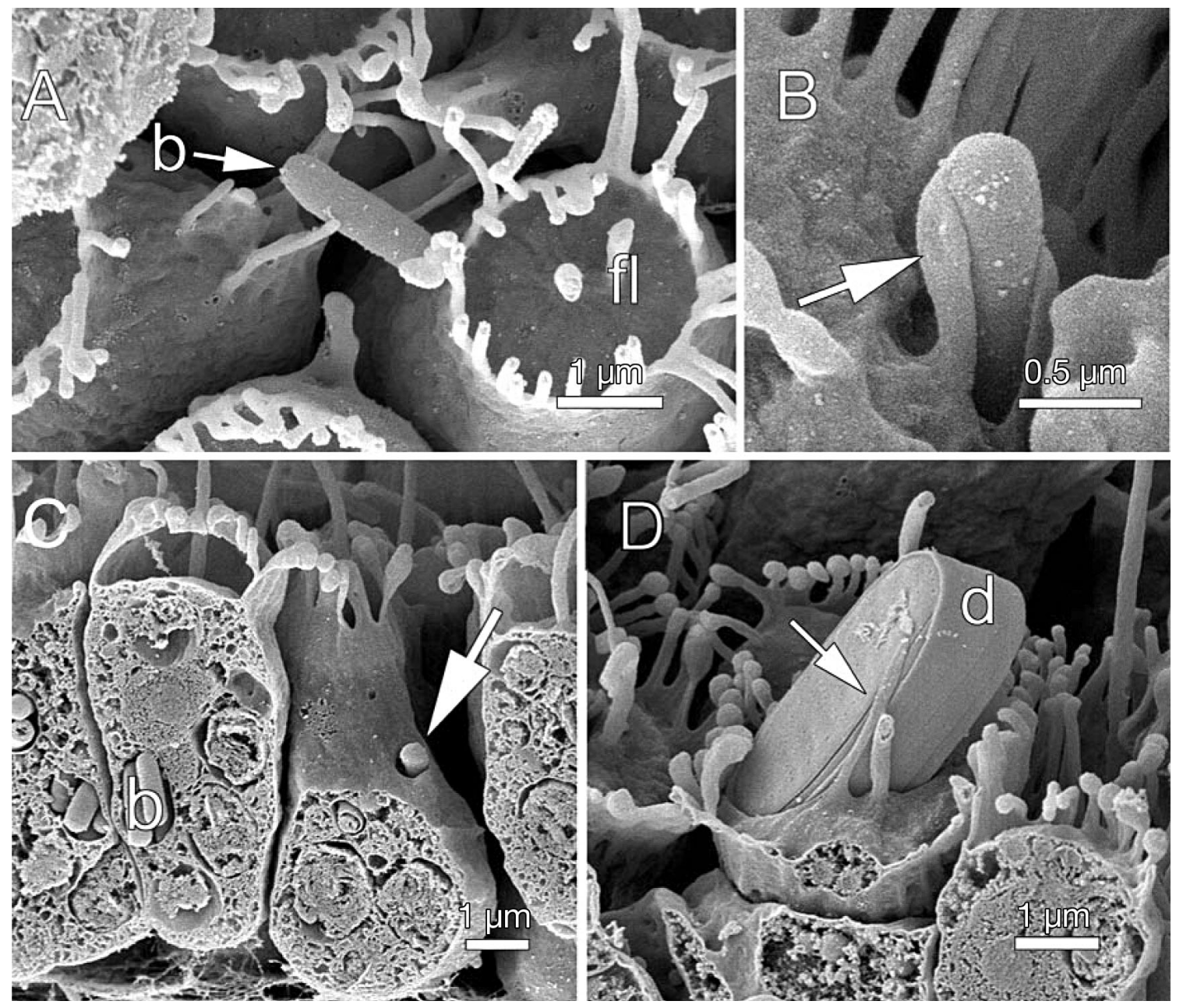

Fig. 2. Sycon coactum. Uptake of bacteria Escherichia coli by choanocytes of the calcareous sponge, scanning electron micrographs. (A) Extensions from several choanocytes towards a bacterium (b), fl = flagellum. (B) Bacterium being engulfed by a lamellipodium (arrow) at the side of a choanocyte. (C) Bacteria (b, and arrow) phagocytosed by a choanocyte. (D) Diatom (d) being engulfed at the apical surface of a choanocyte. A lamellipodium (arrow) lies along the length of the diatom. From Leys \& Eerkes-Medrano (2006)

of the laterofrontal cirri the through-current passes mainly around the laterofrontal cirri in an oscillatory, unsteady, 3-dimensional pattern and that only a little flow may leak through the branching cilia.

In mussels and other bivalves with compound laterofrontal cirri, particles $>4 \mu \mathrm{m}$ are retained with $100 \%$ efficiency by the gills (Vahl 1973, Møhlenberg \& Riisgård 1978, Jørgensen et al. 1984, Riisgård 1988). Large, compound, laterofrontal cirri are widespread throughout the Bivalvia (the vast majority of species); with some notable exceptions such as scallops (pectinids), Monia squana, Anomia achaeus and Pteria macroptera (Riisgård \& Larsen 2005), all occurr in the relatively few heterorhabdic (i.e. gill having more than one type of filament) taxa (Owen \& McCrae 1976).

\section{Suspension-feeding without laterofrontal cirri}

The basic particle capture mechanism in those bivalves that only possess pro-laterofrontal cilia remains poorly understood (Nelson 1960, Owen \& McCrae 1976, Beninger et al. 1988, Beninger et al. 1992, 2004, Silverman et al. 1995, 1996, Riisgård \& Larsen 2001, 2005). According to Owen \& McCrae (1976), the laterofrontal tracts of the plicate gill of the scallop Chlamys varia consist of a single row of prolaterofrontal cilia that are 12 to $15 \mu \mathrm{m}$ long and spaced 0.3 to $0.4 \mu \mathrm{m}$ apart and their effective beat is towards the frontal face of the filament.

Bivalve species that only possess pro-laterofrontal cilia are less efficient at retaining particles than species with laterofrontal cirri (Møhlenberg \& Riisgård 1978, Jør- 


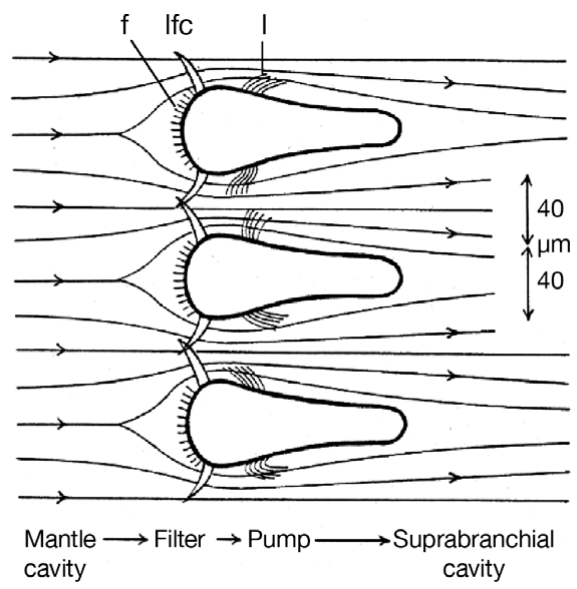

Fig. 3. Mytilus edulis. Sketch of cross section through 3 gill filaments. $\mathrm{f}=$ frontal cilia (beating into the plane of the diagram); lfc = laterofrontal cirri (effective stroke to the left of the diagram) 1 l = lateral cilia (effective stroke to the right). From Silvester \& Sleigh (1984)

gensen et al. 1984, McHenery \& Birkbeck 1985, Riisgård 1988, Jørgensen 1990). The reported ability of the pectinids Aequipecten (Pecten) opercularis, Pseudamussium (Chlamys) septemradiatum (Møhlenberg \& Riisgård 1978) and Argopecten irradians (Riisgård 1988) to retain completely particles $>\sim 6 \mu \mathrm{m}$ in diameter makes it interesting to clarify if the pro-laterofrontal cilia play an active role in the retention of particles. However, according to Owen \& McCrae (1976), an examination of the plicate gill of Chlamys varia (Fig. 6) suggests that the collection of particles is dependent upon the flow of water currents rather than the direct filtration and transport of particles by cilia.
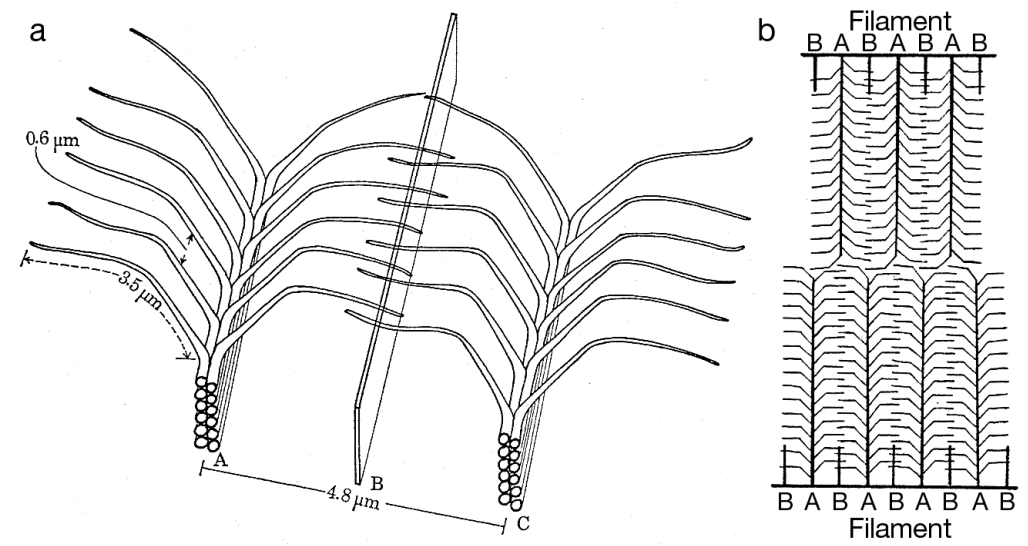

Fig. 4. Mytilus edulis. (a) Diagrammatic representation of 2 alternate laterofrontal cirri (A and C), and the adjacent cirrus (B) which is out of phase with cirri A and C by half a beat. From Owen (1974). (b) Frontal view of the interfilament space at the level of the laterofrontal cirri. Alternate cirri (A) are extended across the space while intervening cirri (B) are bent towards the frontal surface. From Silvester \& Sleigh (1984)

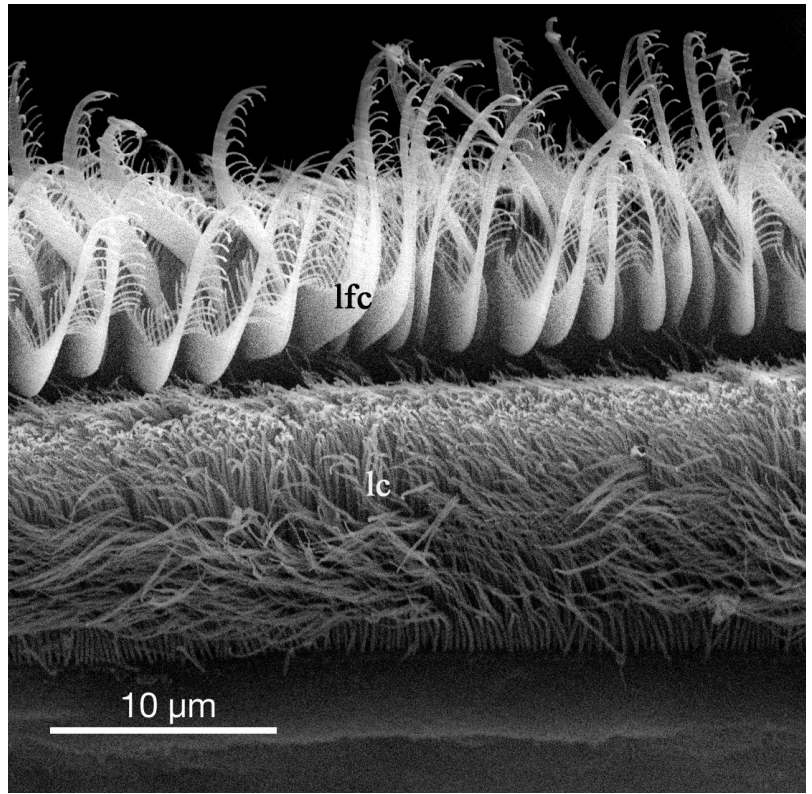

Fig. 5. Mytilus edulis. Scanning electron micrograph of a single gill filament with a band of water-pumping lateral cilia (lc) and a row of particle-capturing laterofrontal cirri (lfc). The lateral cilia are inactive because the nerve has been cut. Photo courtesy of Peter Funch

The interpretation made by Owen \& McCrae (1976) of the mechanism of feeding and of ciliary currents was apparently in agreement with stereoscopic observations of living, non-narcotized specimens studied by Beninger et al. (1988). Furthermore, Beninger et al. (1992) found that direct endoscopic observations of particles arriving at the scallop gill apparently confirmed in vivo the previously proposed mechanism of particle capture. The in-current flow was observed to be parallel to the gill filaments, proceeding dorsally while being deflected into the interplicate grooves. This current appeared to be created by the ciliated frontal surfaces of the principal filaments and the lateral cilia of the ordinary filaments, and capture was suggested to be effected hydrodynamically by the currents produced by the frontal cilia on the principal filament. However, video recordings of the intact plicate gills of Aequipecten opercularis made by Riisgård \& Larsen (2005) showed that particles approach the frontal side of the ordinary gill filaments at angles near $90^{\circ}$ and that particles may be deflected from the through-flow to 'jump' down across these filaments towards the principal filament (see also Beninger et al. 1992). Observations of 
isolated gill filaments indicate that the pro-laterofrontal cilia ahead of the lateral water-pumping cilia may 'push' suspended particles, or fluid with particles, back against the current, either onto the frontal side of the filament, or out into the downward-directed water flow in the funnel-shaped groove between 2 gill crests. Twodimensional numerical flow calculations suggest flowdriven mechanisms are responsible for the transfer of particles to the frontal sides of ordinary filaments or into the main downward-directed flow between 2 plicate gill crests, contributing to the observed 'jumps'.

Studies by Beninger et al. (2005) and Cannuel \& Beninger (2007) of particle processing on the gill plicae of the pseudolamellibranch oyster Crassostrea gigas show that the capture mechanism of particles initially rejected at the gill involves the apical filament only, with the other plical filaments serving to channel the water flow and support the plical architecture that is essential to the capture of initially accepted particles by the principal filaments. However, note that the capture mechanism changes from ciliary downstream collecting in veliger larvae (see 'Ciliary downstream collecting') to cirri trapping during the postlarval development of most bivalves (e.g. Cannuel et al. 2009)

Finally, it should be emphasized that qualitative selection in suspension-feeding bivalves has been assumed to be exclusively post-capture, but in the tropical bivalve Lithophaga simplex studied by Yahel et al. (2009), qualitative selection occurs prior to retention. This encourages a re-examination of what is meant by 'retention'.

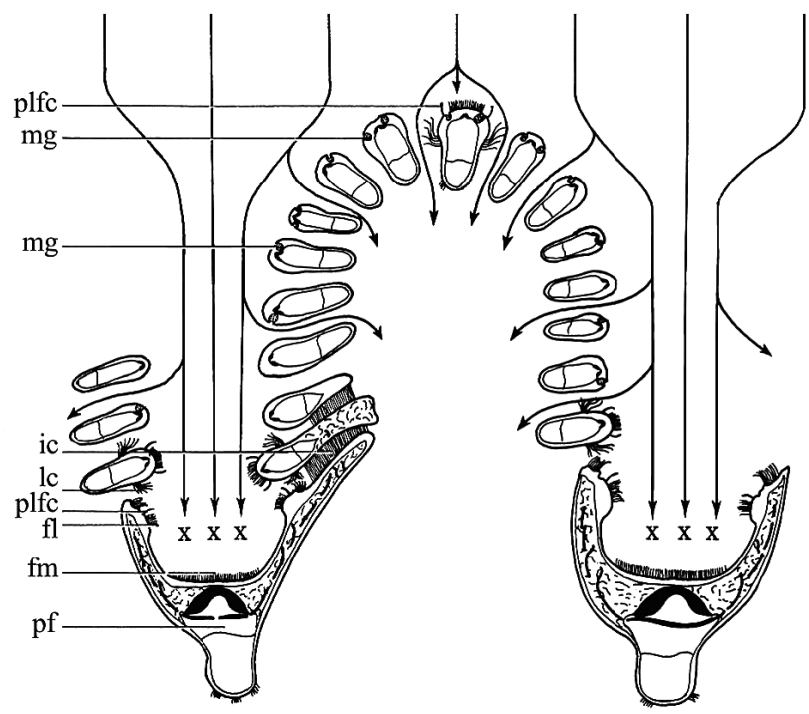

Fig. 6. Chlamys varia. Cross section of the plicate gill lamella showing 1 complete gill crest. Arrows indicate flow of water toward the gill surface and through the interfilamental canals; $\mathrm{X}$ indicates a dorsally directed flow in the gutters formed by the U-shaped principal filaments (pf). plfc $=$ pro-laterofrontal cilia; $\mathrm{mg}=$ mucus gland; ic $=$ interlocking cilia; $\mathrm{lc}=$ lateral cilia; $\mathrm{fl}=$ lateral tract of frontal cilia; $\mathrm{fm}=$ median tract of frontal cilia. From Owen \& McCrae (1976)

\section{Ciliary sieving — upstream collecting}

The term 'ciliary sieving' is used to describe ciliary filter-feeding in bryozoans (= ectoprocts) (Riisgård \& Larsen 2001, Nielsen 2002, Larsen \& Riisgård 2002), but it applies equally well to phoronids and brachiopods.

\section{Bryozoans}

The tentacle structures and ciliary particle capture mechanisms in bryozoans have been studied thoroughly over many years (Atkins 1932, Lutaud 1973, Gordon 1974, Ryland 1976, Winston 1977, 1978, Strathmann 1982, 2006, Strathmann \& McEdward 1986, Gordon et al. 1987, Nielsen 1987, 2001, 2002a,b, Mukai et al. 1997, Riisgård \& Manríquez 1997, Nielsen \& Riisgård 1998, Riisgård et al. 2004, 2009). The lateral ciliary bands of bryozoan tentacles produce feeding currents directed down into the lophophore and out between the tentacles (Figs. $7 \& 8$ ). The design of the lophophore ensures a relatively strong core-current directed straight towards the mouth. A row of sensory stiff laterofrontal cilia is positioned upstream of this water-pumping band. Particles in the currents are retained by the laterofrontal ciliary filter (i.e. ciliary sieving) and subsequently either transferred to the frontal surface of the tentacles to be transported towards the mouth by means of the frontal cilia, or the particles are transferred to the core-current by means of inward tentacle flicks triggered by the drag force of the water current on the captured particles (Fig. 9) (see reviews by Riisgård \& Larsen 2001, Larsen \& Riisgård 2002). A strong central lophophore current is crucial for the gymnolaemates and for some phylactomates where tentacle flicks serve to transfer arrested particles near the tentacle tip back into this current. Riisgård et al. (2004) suggested that, in addition to tentacle flicking, the deflection of the sensory laterofrontal cilia caused by an arrested particle in the lower part of the lophophore may trigger either an inward flick of the otherwise stiff laterofrontal cilia, pushing the restrained particle back into the core-current, or the particle may induce a temporary local change (or a stop) in the beat of the lateral cilia.

The description of the latter mechanism originates from Strathmann (1982) who observed that a lateral cilia band of length $\sim 100 \mu \mathrm{m}$ reversed beat for about $200 \mathrm{~ms}$, amounting to only 2 to 4 beat periods at 10 to $20 \mathrm{~Hz}$. The high-speed video recordings by Strathmann (2006) demonstrated that cyphonautes larvae sieve particles by means of stiff laterofrontal cilia that may either themselves be triggered to flick when stimulated by the drag of a captured particle, or this stimulus may trigger the water-pumping lateral cilia to 


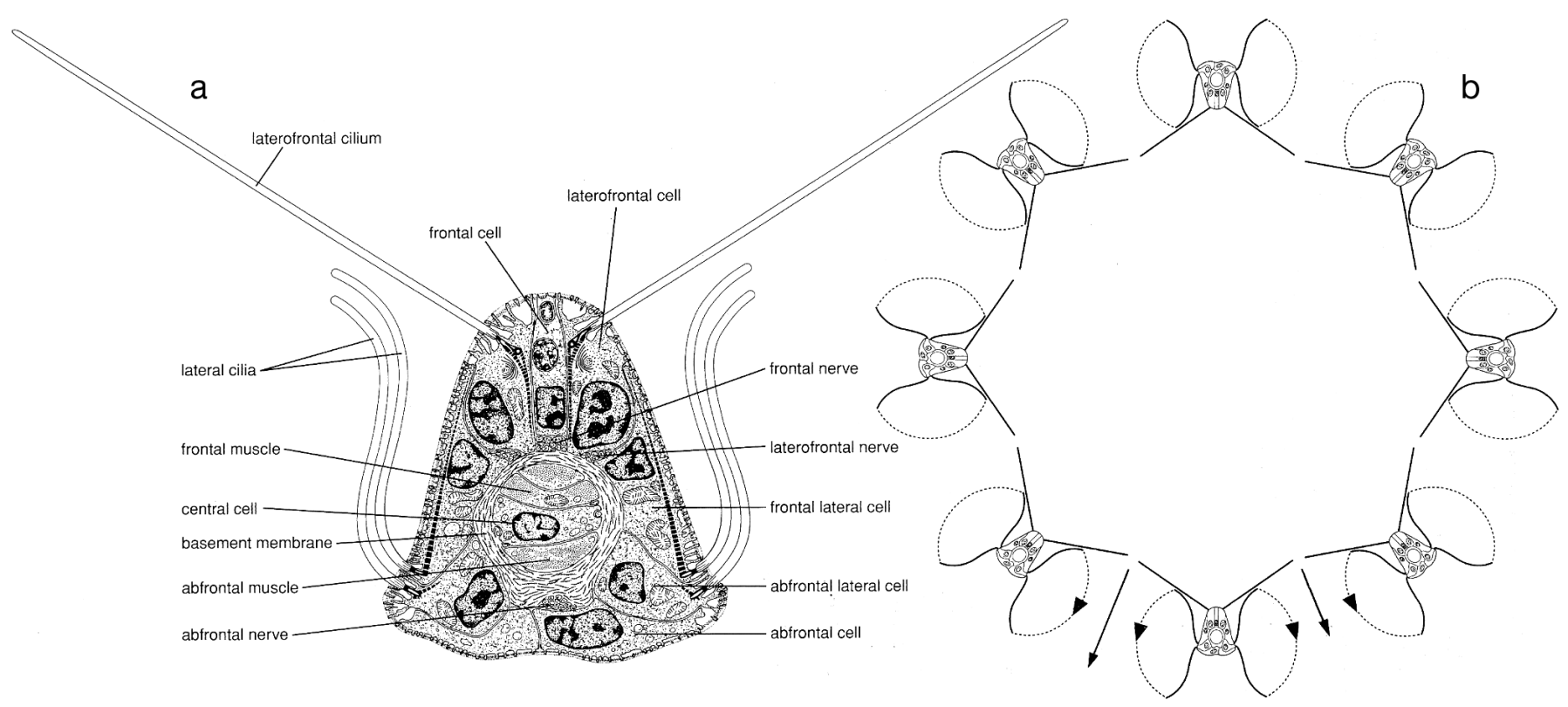

Fig. 7. Crisia eburnea. (a) Diagram of a transverse section of a tentacle based on scanning and transmission electron microscopy (SEM, TEM) observations. (b) Sketch of the C. eburnea filter-pump showing a cross section of the median part of the tentacle crown. Note the lack of frontal cilia. The lateral 'pump' cilia on the 8 tentacles provide the power drawing the water (arrows) through the crown. Suspended food particles are separated from the flow by the sensory laterofrontal cilia which act as a mechanical filter. A retained particle triggers the tentacle to flick inwards, pushing the particle into the fast center-current which carries the particle to the mouth. From Nielsen \& Riisgård (1998)

change beat and, thus, produce a backcurrent that moves the captured particle against the direction of the feeding current. This mechanism could also explain the 'jumps' of particles that often occur without a tentacle flick in adult bryozoans (Riisgård 2002). For example, the 'jumps' in the lower part of the lophophore observed in the freshwater bryozoan Paludicella articulata (Riisgård et al. 2004) extend beyond the reach of a laterofrontal cilium and against the usual direction of the feeding current.

\section{Phoronids and brachiopods}

The filtering mechanism of phoronids and probably also of brachiopods is very similar to that described for bryozoans (see previous section), and is of the 'upstream-collecting' type, i.e. particles are captured on the upstream-side of the current-producing ciliary band (Strathmann 1973, Nielsen \& Rostgaard 1976). But this definition is too imprecise, and therefore we suggest the term 'ciliary sieving' to describe particle capture in ciliary suspension-feeding in bryozoans, phoronids and brachiopods that use stiff laterofrontal cilia for sieving the feeding current.

Particle capture in larval and adult Phoronis muelleri was studied by Riisgård (2002) who found that in the adult, when an incoming particle is stopped near the tip of a tentacle, a flick is triggered which brings the particle down towards the mouth. Particles stopped further down the tentacle are either transported down along the frontal surface of the tentacle by means of the frontal cilia, or transferred into the downward current created by the lophophore. In the actinotrocha larva, a large hood (epistome) aids particle transport by rapid lifts that suck the particles towards the mouth (Strathmann \& Bone 1997, Riisgård 2002). Essential features of the filter-feeding process in both larval and adult phoronids resemble those of the marine bryozoans, but the tentacle flicks made by $P$. muelleri are more sinuous and this may enable the tentacles to keep an arrested particle close to the frontal side of the tentacle during the whole flick cycle. This suggests that phoronids may not be dependent on a central lophophore current (Riisgård 2002).

Brachiopod larvae and adults are suspension feeders and have a lophophore as a feeding organ. The circular lophophore of the larvae becomes coiled in various ways in the adults and, in most brachiopod adults these have 2 series of flexible tentacles. Ciliary tracts on the lateral sides of the tentacles produce a current of water that passes between the tentacles. Whereas the relatively long lateral cilia create the feeding current, shorter frontal cilia transport the captured particles towards the mouth. Laterofrontal cilia have been observed in Lingula anatina (Nielsen 1987, his Fig. 27C) and Laqueus californianus (Gilmour 1978). Gilmour (1981) described the structure of the tentacles 
of Glottidia pyramidata and observed that food particles are carried between the outer tentacles and that they may be captured by the laterofrontal cilia. Captured particles are transported down the grooves in water currents generated by the frontal cilia and the 'immobile' laterofrontal cilia are surrounded by rings of microvilli and have long rootlets extending deeply into the cytoplasm. The laterofrontal cells make synapse with the nervous system, and therefore Gilmour (1981) suggested that the stiff laterofrontal cilia may serve as sensory detectors of particles. More recently, Strathmann (2005) observed that larvae of G. pyrami- data retain food particles on the frontal side of the tentacles by means of a sieve composed of a row of stationary laterofrontal cilia. These laterofrontal cilia may remain extended or release particles by bending, and they possibly trigger an action by other cilia (localized changes of ciliary beat) or a contraction of muscles (tentacle flick).

In conclusion, the recent work by Riisgård et al. (2009) and previous studies demonstrate that essential features of the particle capture process resemble each other closely in bryozoans (including phylactolaemates and gymnolaemates), brachiopods and phoronids.
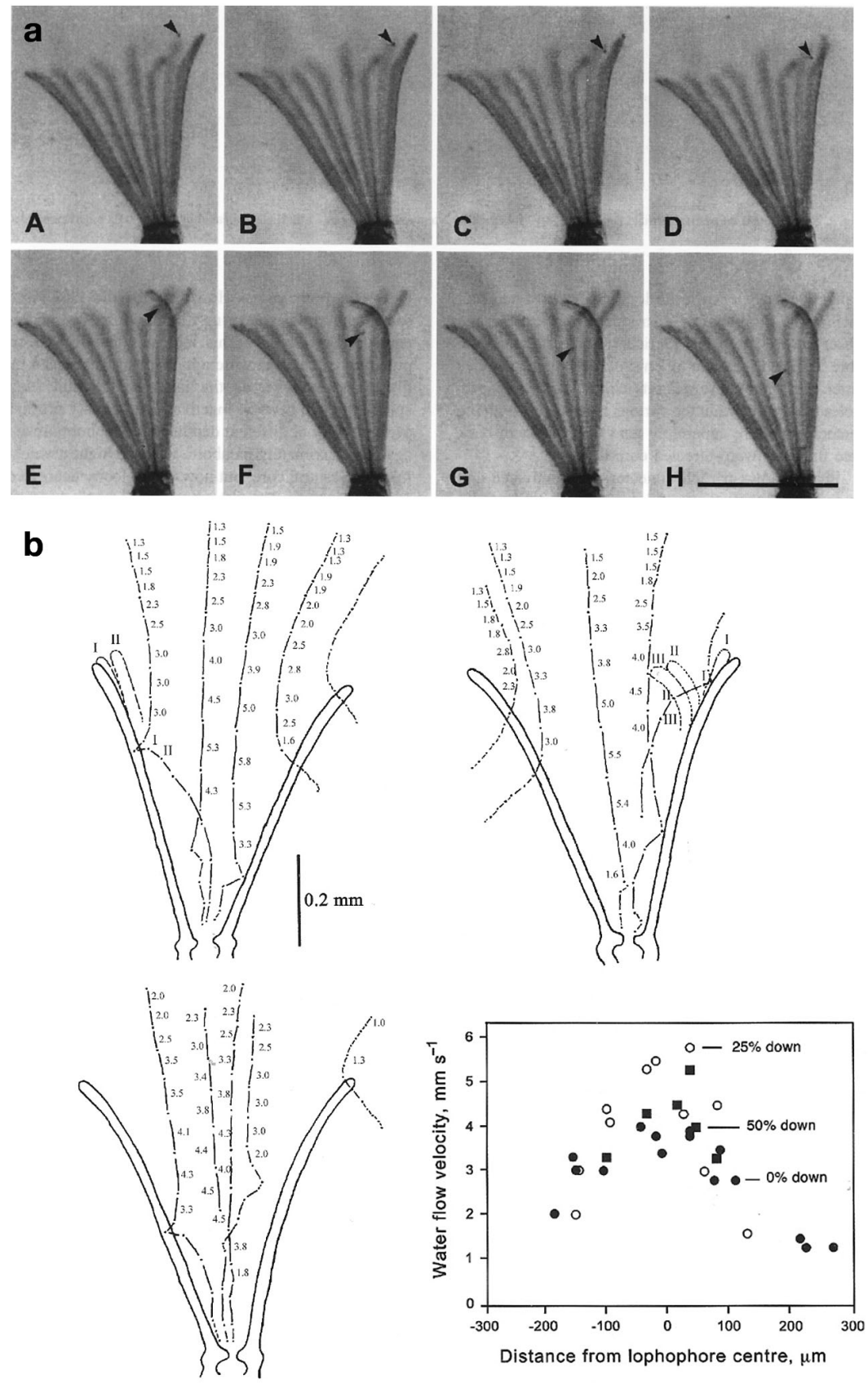

\section{Ciliary downstream collecting}

In ciliary downstream-collecting animals, a ciliary band on a tentacle or pinnule transfers particles from the water current within reach to the downstream side of the band, where the separated particles are taken over by another band of cilia that transports the particles toward the mouth. Ciliary downstream particle collecting is found in different taxonomic groups of invertebrates (Nielsen, 1987, 2001), including meroplanktonic larvae of gastropods (Emlet 1990, Hansen 1991, Romero et al. 2010), bivalves (Strathmann \& Leise 1979, Gallager 1988), and polychaetes (Emlet 1990, Hansen 1993).

Polychaetes are represented in large numbers in many benthic environments. The available information on feeding modes was reviewed by Fauchald \& Jumars (1979) who noted

Fig. 8. Bowerbankia imbricata. (a) Particle (6 $\mathrm{mm}$ diameter algal cell, arrow) arrival and capture on a tentacle (A to D) followed by an individual tentacle flick $(\mathrm{E}, \mathrm{F})$ which transfers the particle into the central current and thus further down towards the mouth $(\mathrm{G}, \mathrm{H})$. $0.02 \mathrm{~s}$ between video-graphic prints. (b) Drawings: examples of particle trajectories in lophophore. Particles captured on the distal part of a tentacle may trigger a tentacle flick (I, II and III indicated by dotted tentacles). Flow lines and velocities $\left(\mathrm{mm} \mathrm{s}^{-1}\right)$ are based on a time interval of $0.02 \mathrm{~s}$ between subsequent video-frames of particles. Plot, right bottom: velocity profile at 0,25 and $50 \%$ down from the top of the lophophore. Highest velocity occurs about $25 \%$ down. From Larsen \& Riisgård (2002) 

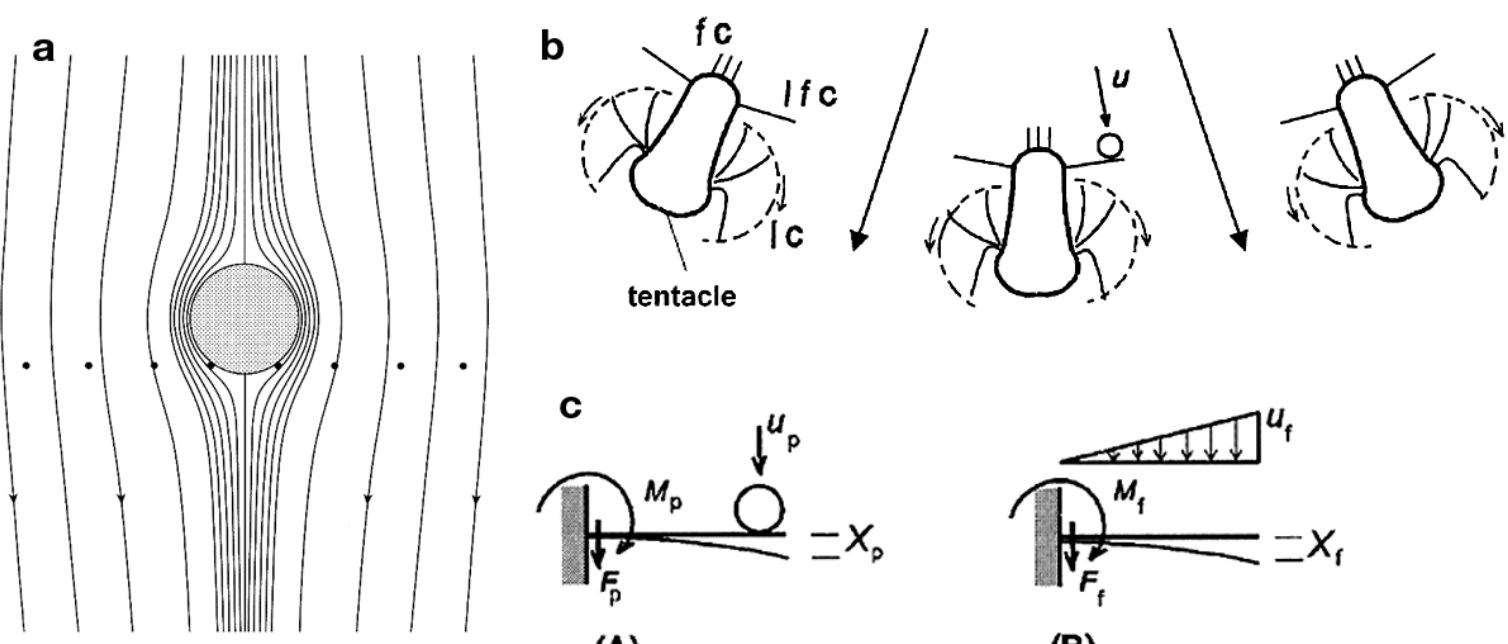

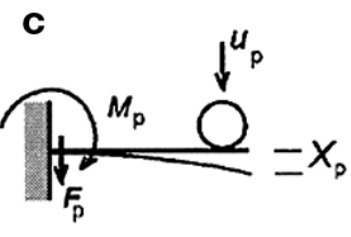

(A)

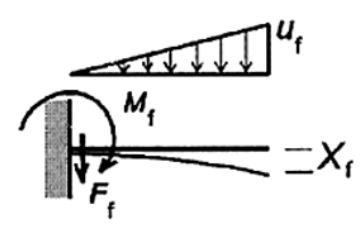

(B)

Fig. 9. (a) Theoretical streamlines for creeping flow through the bryozoan laterofrontal ciliary filter which has stopped a $6 \mu \mathrm{m}$ algal cell (shaded). The drag force on the food particle presumably deflects the $0.2 \mu \mathrm{m}$ diameter sensory laterofrontal cilia (black dots), and this triggers the tentacle flick. From Nielsen \& Riisgård (1998). (b) Cross section of 3 tentacles of a lophophore with frontal cilia (fc), water pumping lateral cilia (lc), stiff laterofrontal cilia (lfc) acting as a mechanical sieve, and a stopped particle subject to downward water velocity $u$. (c) Laterofrontal cilium subject to load from (A) drag on particle and (B) 'background' drag on cilium from water velocity, increasing linearly from root to tip, both giving rise to force $F$, bending moment $M$ at point of fixation to tentacle, and deflection of cilium tip X. (b,c) From Larsen \& Riisgård (2002)

that suspension-feeding had been documented in Chaetopteridae, Oweniidae, Sabellariidae, Fabriciinae, Sepulidae-Spirorbidae, and Spionidae. Some of the species are partially or wholly suspension feeders (Buhr 1976, Taghon et al. 1980, Miller et al. 1992, Riisgård \& Kamermans 2001). Fig. 10 gives examples of ciliary downstream collecting in a polychaete, together with an entoproct and a cycliophore using the same feeding mode. This mode of collection is, thus, a widespread basic feeding principle, used across taxonomic boundaries and adequately working in spite of (often) great variation in functional morphology of the feeding organs.

Downstream collecting has been studied in adult specimens of the polychaetes Sabella penicillus (Riisgård \& Ivarsson 1990, Mayer 1994), Spirorbis tridentatus, the entoproct Loxosoma pectinaricola, and the cycliophore Symbion pandora (Riisgård et al. 2000). The ciliary bands show some general structural similarities in all groups, as appears from the descriptions that follow.

The interpretation of observations of structure and activity of the ciliary bands in Loxosoma pectinaricola as summarized by Riisgård et al. (2000) serve as a general description of ciliary downstream collecting. In L. pectinaricola, video-observations of the paths and velocities of particles showed that suspended particles within reach are accelerated with the water that enters the region swept by the compound lateral cilia and then become caught up by one, or more likely by several, of the compound cilia in their power stroke
(Fig. 10c). This element in the process, denoted the 'catch-up principle' by Riisgård et al. (2000), accelerates a particle and rapidly moves it in a curved path to the midline at the frontal side of the pinnule, i.e. on the downstream side. In this phase of the power stroke the particle is pushed out of the main water current which moves past the tentacle, and as the compound lateral cilia come to rest in their angular motion so does the particle and surrounding fluid. Subsequently, the frontal cilia carry the particle to the food groove and mouth. The basic principle of particle catch-up as adopted for $L$. pectinaricola (and $S$. tridentatus, $S$. penicillus, and others) also applies to the cycliophore $S$. pandora where the principle of opposed ciliary bands has instead been obtained by a ciliated mouth ring and where the frontal cilia are replaced by a ciliated mouth cavity.

The capture mechanism in all ciliary downstreamcollecting suspension-feeders is based on the same basic principle described by the catch-up hypothesis. According to this hypothesis, compound cilia constitute the pump, which generates a flow with suspended particles that enters the ciliary region. In this region the same cilia, during their power stroke, catch up with suspended particles and transfer the particles to a food grove, or a mouth cavity. In the particle-size retention spectrum, the lower size limit presumably depends on the spacing between cilia that beat in phase, while the upper size limit depends on cilia length which may or may not allow particles to enter the ciliary region. The last phase of transfer likely involves interactions with 

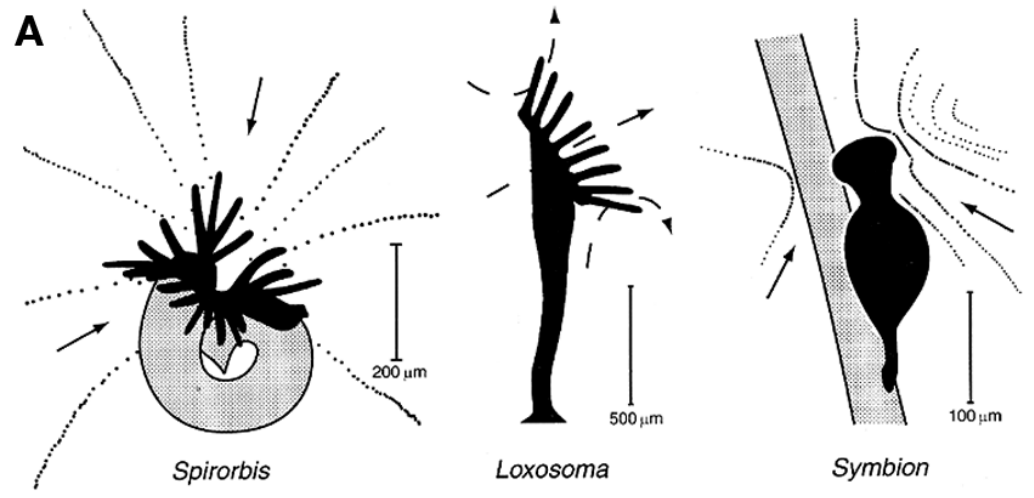

Loxosoma

Symbion

B

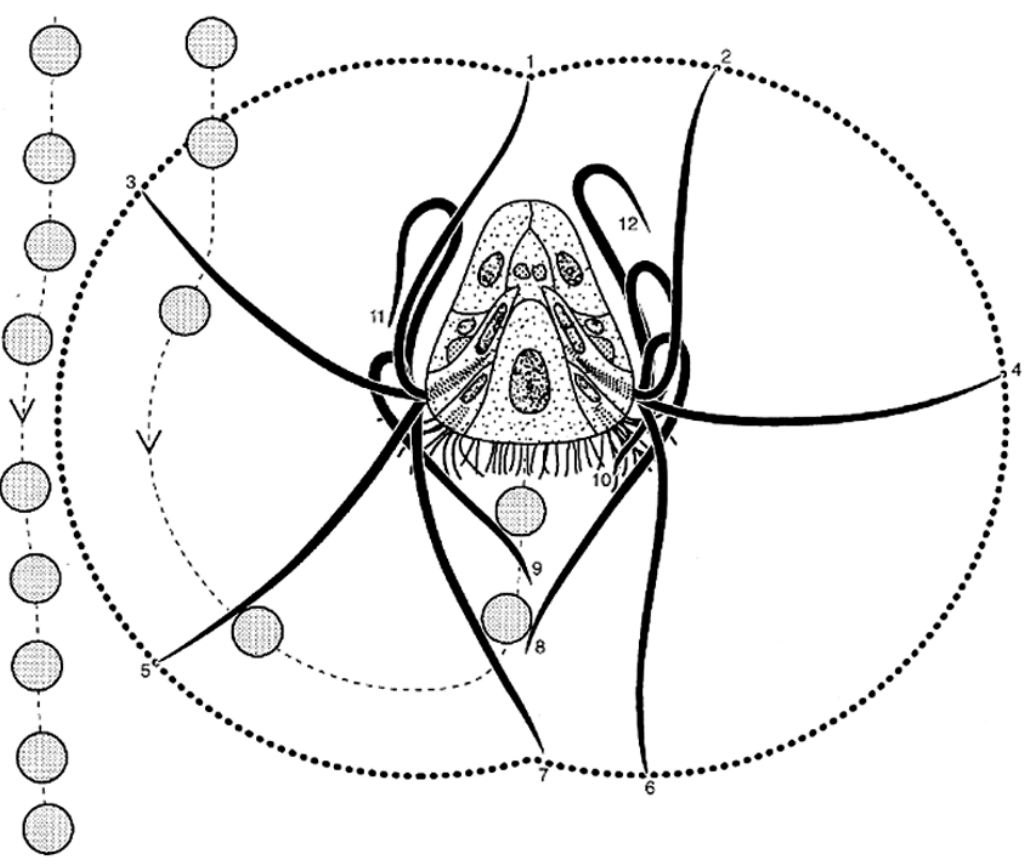

C
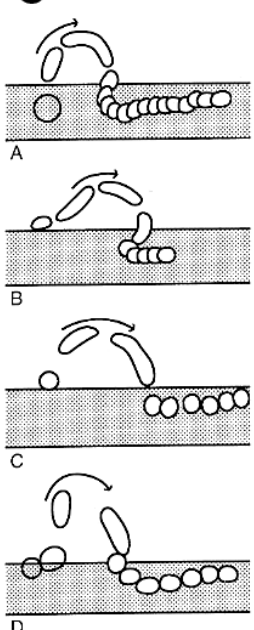
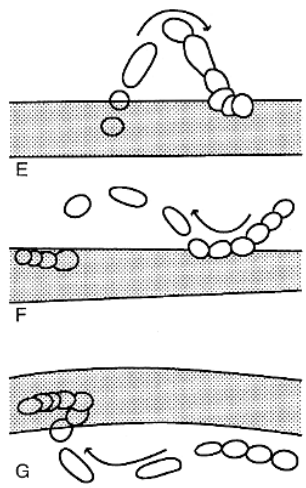

$\circ$

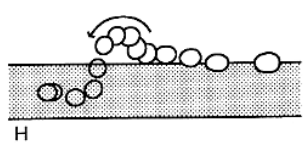

Fig. 10. (A) Flow fields generated by the polychaete Spirorbis tridentatus (seen from above), the entoproct Loxosoma pectinaricola (in lateral view) and the cycliophore Symbion pandora (seen from behind on a seta of the Norway lobster Nephrops). The animals, which all capture particles by means of the catch-up principle, are shown as silhouettes and the tube of Spirorbis and the seta of Nephrops are shaded. The flow patterns of Spirorbis and Symbion are indicated by dots drawn from video recordings with $0.02 \mathrm{~s}$ intervals, showing particles entering the tentacle crown or the buccal ciliary ring. In Spirorbis, the filtered water leaves the tentacle crown in an obliquely upwarddirected flow that is not indicated. The flow pattern of Loxosoma is hypothetical for stagnant water; the animal is normally situated in the respiration current of the host polychaete. (B) Loxosoma pectinaricola. Sketch of a cross section of a tentacle showing how the compound lateral cilia catch up a particle which then becomes accelerated and transferred to the frontal side of the tentacle. The dotted line indicates the zone covered by the lateral cilia. Positions of compound lateral cilia in active stroke (1-7) and recovery phase (8-12) are shown. (C) Spirorbis tridentatus. Examples (A-J) of particle capture. Time interval between successive video frames $=0.02 \mathrm{~s}$. All from Riisgård et al. (2000)

other cilia systems that act to prevent intercepted particles from escaping with the main through-flow.

\section{Mucus-net suspension-feeding}

Suspension feeding by means of an efficient mucus net which sieves the feeding current has independently evolved in several different taxonomic groups of marine animals (e.g. polychaetes, ascidians, salps, larvaceans, gastropods). Several examples of this adaptation to feeding on a dilute suspension of microscopic food particles, including free-living bacteria, are given below.

\section{Polychaetes}

Chaetopterus variopedatus: a mucusnet suspension-feeding polychaete that lives in a parchment-like tube, which it secretes. The suspension-feeding 
mechanism has been described, and different aspects of water pumping and particle retention have been studied (MacGinitie 1939, Wells \& Dales 1951, Brown 1977, Flood \& Fiala-Médioni 1982, Jørgensen et al. 1984, Riisgård 1989). A flow of water through the tube is driven in the antero-posterior direction by 3 muscular piston-like parapods in the middle region of the body (Segments 14, 15 and 16, see Fig. 11A). Two aliform notopodia (Segment 12) continously secrete a mucus-net bag that filters the tubal water current. The posterior end of the suspended mucus-net bag is rolled up into a food ball within the dorsal capule, a ciliated cup-like organ (Segment 13), and is ingested at intervals of 15 to 20 min (MacGinitie 1939). The mucus net is built of longitudinal parallel fibre bundles and transverse filaments forming a rectangular meshwork (Flood \& Fiala-Médioni 1982) which efficiently retains suspended food particles down to $\sim 1 \mu \mathrm{m}$ (Jørgensen et al. 1984).

The family Chaetopteridae is well-known in terms of feeding modes. Besides the above-mentioned 'pistonpump mucus-net' feeding mode of Chaetopterus variopedatus, 5 additional species of chaetopterids use similar filter nets (Barnes, 1964, 1965). In some instances a single net is employed (Telepsavus costarum, Ranzanides sagittaria), but in other cases several nets are formed on successive segments (Spiochaetoptrus oculatus, Phyllochaetopterus socialis, Mesochaetopterus taylori). In S. oculatus, T. costarum, and P. socialis the water current through the tube is generated by ciliary rings of the foliaceous notopodia, whereas $R$. sagittaria and $M$. taylori pump water through the tube by means of peristaltic contractions of a several segments of the middle body region. These examples illustrate the flexibility by which ciliary pumps, muscular piston pumps and muscular peristalltic pumps are employed more or less indiscriminately also within closely related species that may use either one big or several smaller mucus nets for straining the tubal water current.

Nereis diversicolor: a common and abundant polychaete that lives in a U-shaped burrow in soft sediment. $N$. diversicolor is described as a carnivore and/or scavenger, but also as a suspension-feeder and a detritivore, feeding partly by swallowing surface mud around the openings of the burrow (Wells \& Dales 1951, Goerke 1966, Evans 1971, Riisgård 1991, 1994). The occurrence of a suspension-feeding mechanism in N. diversicolor was first described by Harley (1950), and later confirmed by Goerke (1966). Observations of suspension-feeding behaviour were made by Riisgård (1991) on $N$. diversicolor in glass tubes immersed in seawater (Fig. 12). When algal cells are added, the worm moves to one end of the glass tube to fix mucus threads to the glass wall, forming the circular opening
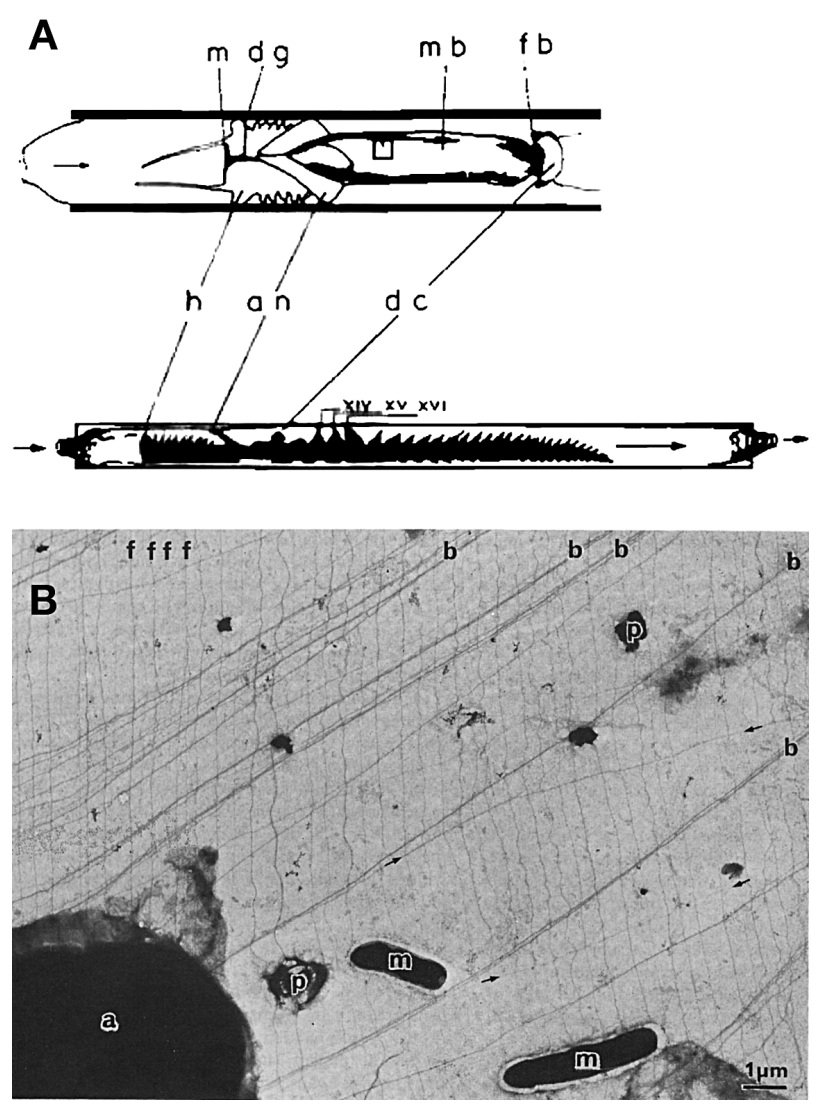

Fig. 11. Chaetopterus variopedatus. (A, lower) Lateral view of worm in a glass tube lined with natural tube material. The water-pumping parapods (XIV, XV, XVI) produce a water current through the tube via the inlet and outlet terminal constrictions. (A, upper) Dorsal view of the anterior end of C. variopedatus lodged in a glass tube. Behind the head $(\mathrm{h})$ the mucus net-bag $(\mathrm{mb})$ is stretched out between the aliform notopodia (an), which secrete the mucus bag, and the dorsal cupula (dc) within which the mucus net is being rolled up as a food ball (fb). At regular intervals the animal stops pumping and contracts, and the food ball is then transported via the dorsal ciliated groove $(\mathrm{dg})$ to the mouth $(\mathrm{m})$. From Riisgård (1989). (B) Electron micrograph of the mucus net location indicated by $\square$ in (A, upper). Structure of mucus net showing a rectangular meshwork composed of an array of mostly parallel fibre bundles (b) perpendicular to an array of parallel filaments (f). A green alga (a) and 2 bacteria (m) and some other particles (p) are trapped in the mucus meshwork. From Flood \& Fiala-Médioni (1982)

of a net bag. This funnel-shaped net bag is completed as the worm retreats down the tube. For a period after the bag is completed, the worm pumps water through the net by means of vigorously undulating movements of the body (peristaltic pump). Particles suspended in the inhalant water are retained by the net and after a period of pumping the worm moves forward, swallowing the net bag and its entrapped food particles.

The food-trapping net of Nereis diversicolor is composed of an irregular mesh made up of long, relatively 
thick filaments (diameter up to $300 \mathrm{~nm}$ ) interconnected with a variety of shorter and thinner filaments (diameter 5 to $\sim 25 \mathrm{~nm}$ ) (Riisgård et al. 1992). The average pore size was between 0.5 and $1.0 \mu \mathrm{m}$ (which due to shrinkage during preparation may represent only $\sim 75 \%$ of the actual dimension of the intact net). Although pore size may exceed the smallest particle size (cf. aerosol/hydrosol filtration theory, see 'Toward an understanding of particle capture'), simultaneous clearance measurements of different-sized particles by Riisgård et al. (1992) showed that particles down to 2 or $3 \mu \mathrm{m}$ are efficiently (near 100\%) cleared from the water. Thus, the retention efficiency of $N$. diversicolor is as good as found in most obligate filter feeders (Jørgensen et al. 1984). It is not known whether suspension feeding is of primary importance for any population of this species, but when the phytoplankton concentration is above a certain 'trigger level', $N$. diversicolor prefers to filter feed, while below the trigger level it switches to one of the alternative feeding modes mentioned at the start of the section (Vedel \& Riisgård 1993, Vedel et al. 1994, Riisgård 1994, Riisgård \& Kamermans 2001).
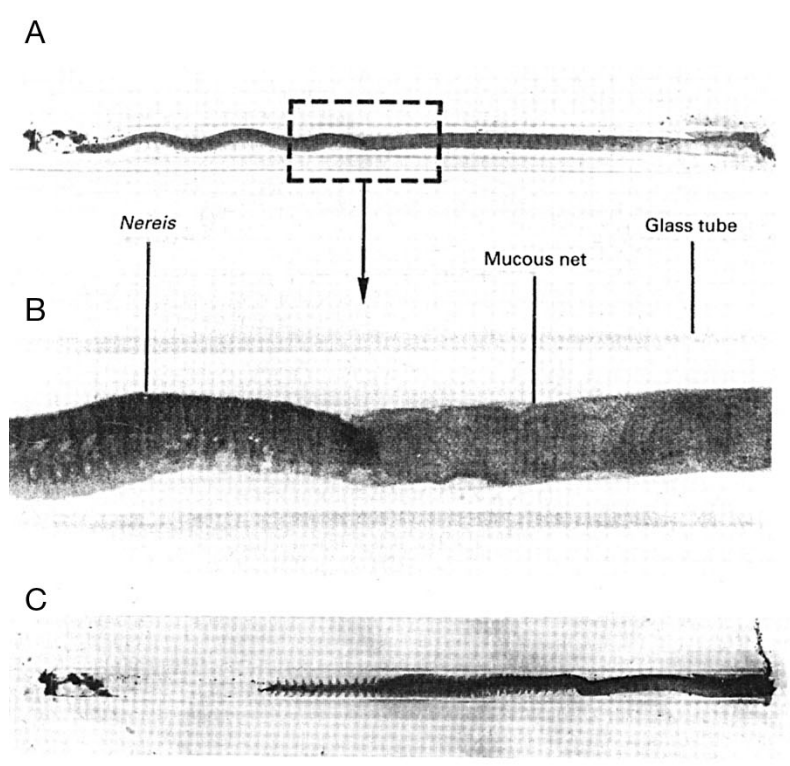

Tunicates

All tunicates (Ascidiacea, Thaliacea, and Larvacea) are suspension feeders, the ascidians are sessile while the 2 other classes are pelagic. They collect food particles in their pharyngeal basket on a mucus filter secreted by the endostyle and ingested with the particles entrapped, but they differ in the way that the filter traps food particles, and the feeding current is produced.

Ascidians: sea squirts pump water through the inhalant siphon into the pharyngeal chamber and through the stigmata into the atrium, from which the water leaves the ascidian as a jet through the exhalant siphon. The pharynx is perforated with small slits (stigmata) and ciliary tracts on either side of the stigmata create the feeding current (Fig. 13A [a,c]). When the water is pumped across the pharynx wall, suspended particles are trapped on a mucus net that is continuously produced by the endostyle (Holley 1986). Cilia on the papillae or longitudinal pharyngeal bars transport the endless mucus net, with the retained food particles, to the dorsal side where it is rolled into a cord which is passed downwards into the oesophagus as an

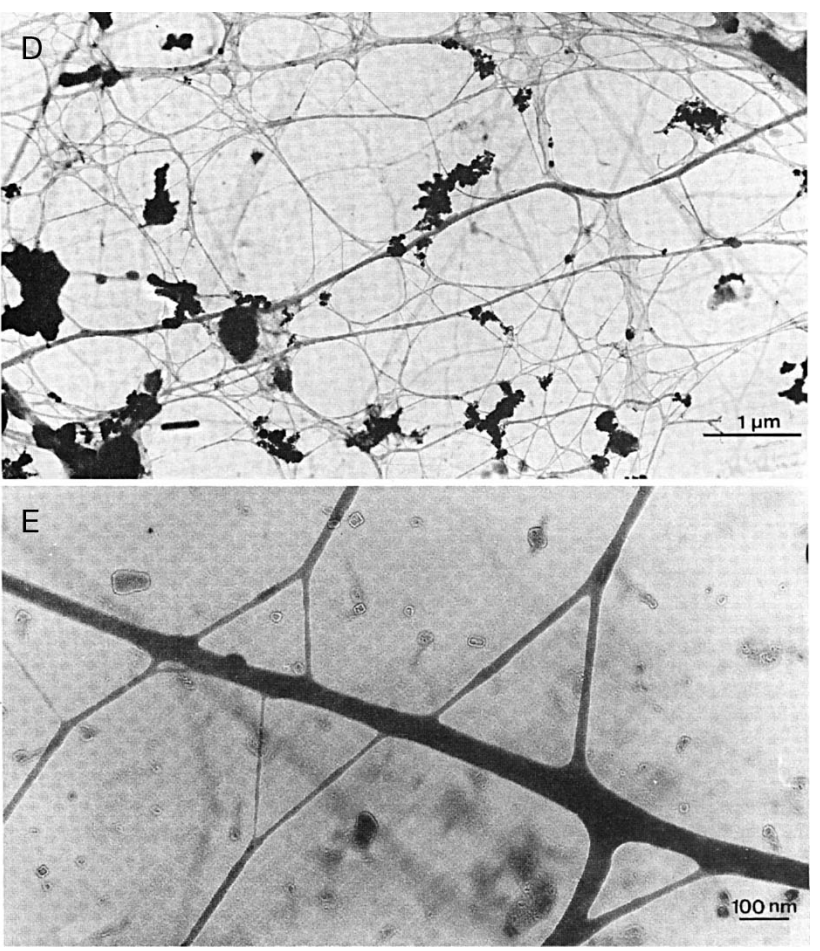

Fig. 12. Nereis diversicolor. (A) Photograph of worm lodged in a glass tube (length $=12 \mathrm{~cm}$ ). The worm is seen from the side to show the undulating body movements that produce a water current through the tube. When the water passes through the tube, it is filtered through a mucus net-bag which has been made visible by means of suspended carmine powder. (B) Magnification of the anterior end of the same worm as shown in (A). (C) Near dorsal-ventral view of the worm while swallowing the mucus net bag 3 min after photograph (A) was taken. $(A, B, C)$ From Riisgård (1991). (D,E) Electron micrographs of mucus net produced by the suspension-feeding worm. (D) Survey at low magnification demonstrating the variation in mesh size. (E) Detail at high magnification showing the relationship between thin and thick filaments. (D,E) From Riisgård et al. (1992) 
continuous string (MacGinitie 1939, Millar 1971, FialaMédioni 1978). Particles down to 2 or $3 \mu \mathrm{m}$ are completely retained (Randløv \& Riisgård 1979, Jørgensen et al. 1984), and electron microscope studies of the mucus net have revealed that in the fixed state, it is composed of 10 to $40 \mathrm{~nm}$ thick fibres arranged in rectangular meshes that vary between 0.2 and $0.5 \mu \mathrm{m}$ in width and between 0.5 and $2.2 \mu \mathrm{m}$ in length (Fig. 13B,C) (Flood \& Fiala-Médioni 1981).

Thaliaceans: the 2 thaliacean salps and doliolids differ in that the mucus-net filter traps food particles in the pharynx, and the water flow across it is produced. In salps, the feeding current is produced by rhythmic contractions of the muscle bands, and the salp moves forwards as it feeds (Bone et al. 1991). In doliolids, ciliated apertures produce the flow through the filter and the doliolid remains almost stationary (Bone et al. 1997).

Salps. Bone et al. (1991) studied the mucus net in Pegea confoederata. Scanning electron micropgraphs (SEM) revealed that it has a regular rectangular mesh consisting of thick $(100 \mathrm{~nm})$ and thin $(50 \mathrm{~nm})$ fibers. The rectangular pores of the mucus filter were $\sim 3.3 \times$ $0.57 \mu \mathrm{m}$, but due to shrinkage the actual pore size in life was suggested to be about $4.0 \times 0.7 \mu \mathrm{m}$.

Dolioids. Feeding in doliolids has been described several times (e.g. Deibel \& Paffenhöfer 1988), most recently by Bone et al. (1997) who re-examined feeding in 2 doliolid species with similar mechanisms. Feeding involves the dorsal spiral volute of the peripharyngeal bands, which rotates the mucus filter in the pharynx so that suspended particles in the inhalant water are trapped between the 2 layers of the filter (Fig. 14).

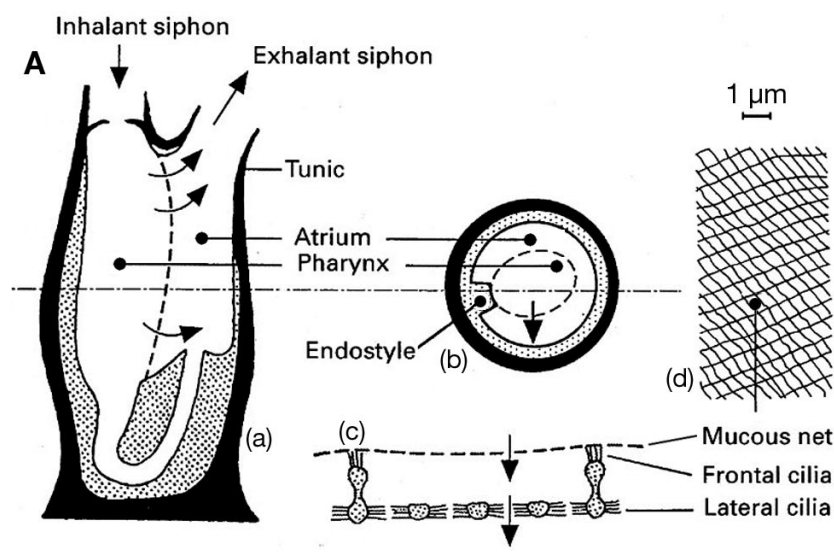

Fig. 13. (A) Diagrammatic longitudinal (a) and transverse (b) sections, and a magnified section through a part of pharynx wall (c) of a typical ascidian (adapted from McNeill Alexander 1975) pumping water (arrows) through a rectangular mucus net $(d)$. $(B, C)$ Food trapping mucus net (mounted directly on grids for TEM) of 2 suspension-feeding ascidians: (B) Styela plicata; $\mathrm{D}=$ a fragment of a diatom shell, $\mathrm{M}=$ cocci-form microorganism; (C) Ciona intestinalis. (B,C) From Flood \& Fiala-Médioni (1981)
Larvaceans (appendicularians): the $\sim 5 \mathrm{~mm}$ long larvaceans are regarded to be neotenic tunicate larvae. Thus, a water-pumping muscular tail is present, and the body resembles an ascidian tadpole larva. A remarkable feature of the larvaceans is the 'house', a complex mucopolysaccharide structure which they secrete and in which the body is either enclosed, e.g. Oikopleura spp. (Alldredge 1977), or to which it is attached, e.g. Fritillaria borealis (Flood 2003). Of the 3 families of larvaceans, the Oikopleuridae is the best known (Jørgensen 1966, Alldredge 1977, Deibel et al. 1985, Deibel 1986, Deibel \& Powell 1987, Flood 1991, Acuña et al. 1996). The sinusoidal beat of the animal's tail draws water into the balloon-like gelatinous house through 2 in-current filters of coarse mucus mesh which pre-screen the water (Fig. 15). Smaller suspended food particles in the incoming water are concentrated by the mucus mesh of the feeding filter. The concentrated food suspension passes to the individual's mouth through a short buccal tube, and finally upon entering the body, the food is collected in the pharyngeal mucus-filter produced by the endostyle (Alldredge 1977, Deibel et al. 1985). The function of the feeding filter has been misrepresented in the past, because it was described as collecting or capturing suspended food particles by means of sieving and adhesion, but according to Deibel (1986) it should more rightfully be called a 'food concentration filter'. In Oikopleura vanhoeffeni water flows into the feeding filter through 2 large, lateral openings at the base of each wing, and along the open distal margins of the filter. Under the hydrostatic pressure generated by the beating tail, water moves through the filter in a 1-way bulk flow

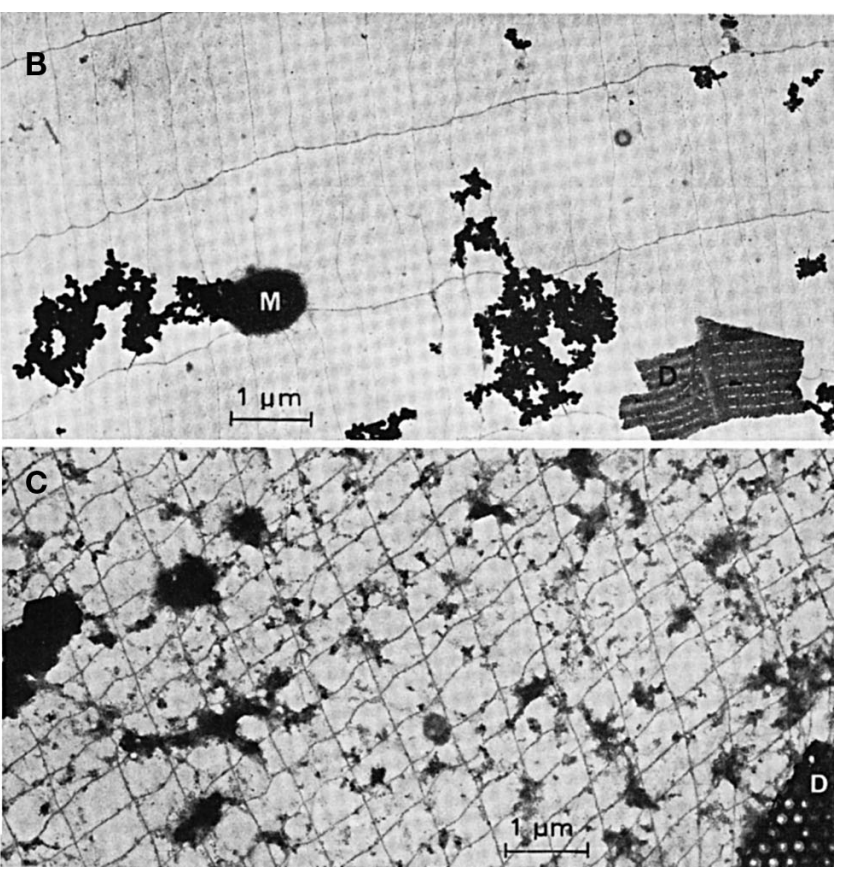


and is forced through the mucus mesh of both the dorsal and ventral layers (interconnected by a third layer of fine fibers which anchor the dorsal and ventral layer to one another in order to resist the hydrostatic pressure). In this way, the feeding filter concentrates the food suspension by sieving most of the incoming water, and the entire surface of both the dorsal and ventral layers operate as a sieve (Deibel 1986). Because of the small pore size of the mesh $(1.04 \times 0.22 \mu \mathrm{m}$, Deibel et al. 1985) the second set of filters inside the house serves as a cross-flow, tangential membrane with $0.2 \mu \mathrm{m}$ pores that concentrates the ambient particle suspension several hundred times (Morris \& Deibel 1993). The animal sucks this concentrated suspension into its mouth and through its internal mucus pharyngeal filter. Particles captured by the pharyngeal filter are rolled into a mucus cord and ingested while the filtrate is drawn through the ciliated spiracles in the floor of the pharynx and into the tail chamber (Acuña et al. 1996). Thus, the pharyngeal filter is ultimately responsible for removing suspended particles for ingestion. Acuña et al. (1996) found that the retention spectra predicted by Silvester's aerosol model (Silvester 1983) duplicate experimental results for particles $>0.6 \mu \mathrm{m}$, whereas predictions from a sieving model do not. Acuña et al. (1996) concluded that 'direct interception is an important particle collection mechanism for particles smaller than the sieve dimension' and that consideration of sieving alone underestimates the actual particle retention efficiency by about $20 \%$.

\section{Cephalochordates (Lancelets)}

Branchiostoma (Amphioxus) lanceolatum is the most common of the transitional species of lancelets, which share characteristics with both vertebrates and invertebrates. Since the early contributions of Orton (1913) and van Weel (1937), several authors have described lancelets as filter feeders (e.g. Barrington 1958, Olsson 1963, Welsch 1975, Baskin \& Detmers 1976, Rähr 1982, Riisgård \& Svane 1999, Ruppert et al. 2000, Nielsen et al. 2007). As an obligate filter feeder $B$. lanceolatum is straining off phytoplankton from the surrounding water. Lancelets lie buried in the bottom gravel with the ventral side turned upward and with the mouth opening free of the bottom (Fig. 16). A feeding current enters at the anterior end of the lancelet between the buccal tentacles and flows through the buccal cavity (vestibule, Fig. 16A,B). Then the water flows successively through the mouth, the branchial basket (pharynx) and mucus filter-net, to the atrium chamber (Fig. 16C), and finally out of the exhalant opening. The water current is maintained through the animal by the

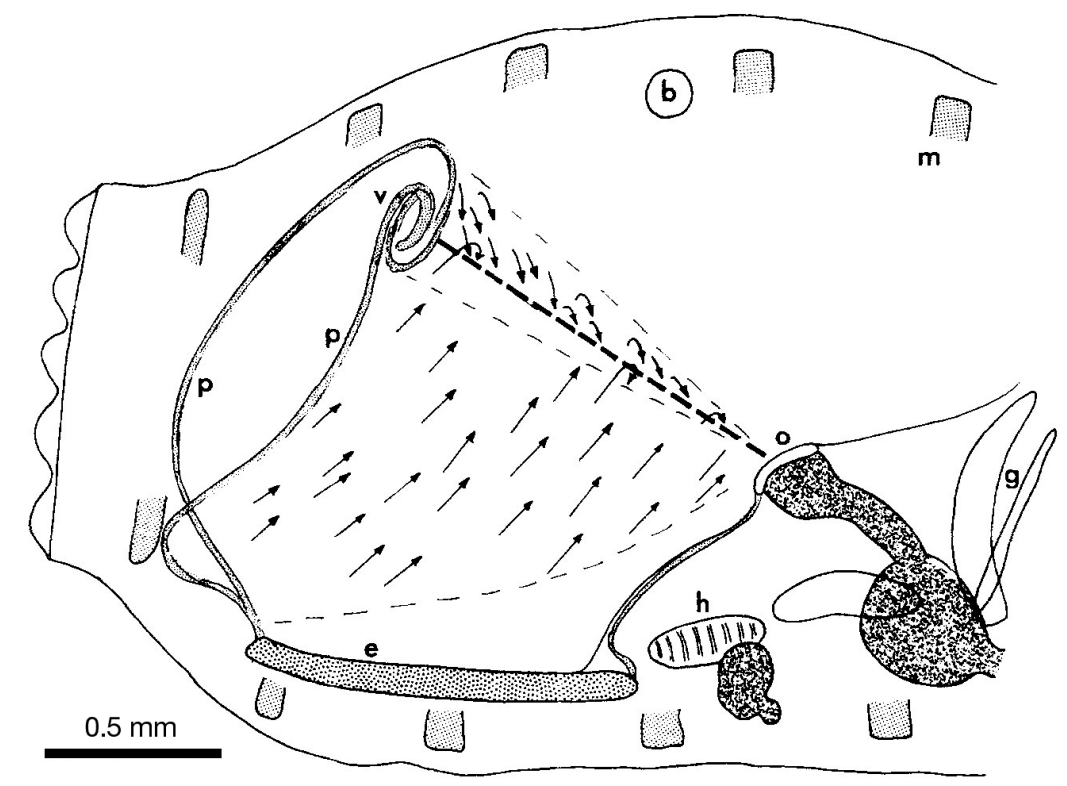

Fig. 14. Doliolum nationalis. Lateral view of feeding oozooid showing the paths of algal cells (arrows) trapped on the mucus filter; dashed lines indicate the limits of the filter. $\mathrm{b}=$ brain, $\mathrm{e}=$ endostyle, $\mathrm{g}=$ gill slits (only some of these are shown), $\mathrm{h}=$ heart, $\mathrm{m}=$ muscle bands, $\mathrm{o}=$ oesophageal opening, $\mathrm{p}=$ peripharyngeal bands, $\mathrm{v}=$ volute. From Bone et al. (1997)

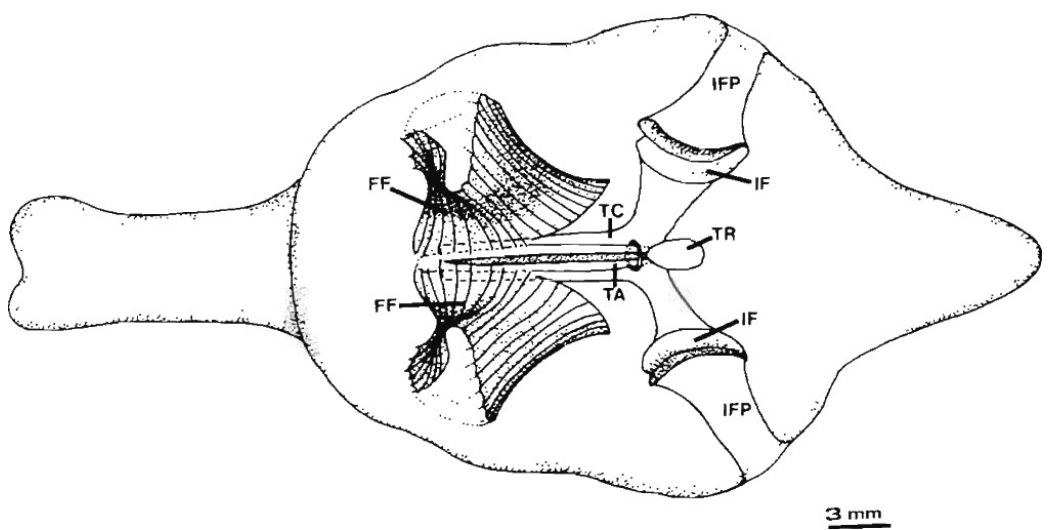

Fig. 15. Oikopleura vanhoeffeni. Dorsal view of larvacean inside its house. FF = feeding filter ('food concentration filter'), IF = in-current filter, IFP = in-current filter passageway, TA = tail, TC = tail chamber, TR = trunk. From Deibel et al. (1985) 
activity of the lateral 'pump' cilia of the branchial septa (Fig. 16D). As particles pass along the pharynx they are drawn up against the internal wall of the branchial basket and the particles become caught in the mucus filter-net. The endostyle in the ventral part of the pharynx produces the mucus filter which is transported along the branchial bars by means of frontal cilia to the dorsal groove where the filters of 2 sides with the captured particles are rolled together and transported posteriorly to the oesophagus (Barrington 1958, Olsson 1963, Welsch 1975, Baskin \& Detmers 1976, Flood 1981, Rähr 1982). Riisgård \& Svane (1999) further described and characterized Branchiostoma lanceolatum as a true filter feeder, and simultaneously measured clearance rates of differently sized particles showed that particles $\geq 4 \mu \mathrm{m}$ are retained by the mucus filternets with $100 \%$ efficiency (see also Ruppert et al. 2000). More recently, Nielsen et al. (2007) showed that 2 to $0.2 \mu \mathrm{m}$ particles are retained with the same efficiency by the apparently sticky strands of the mucus filter, which may not, unlike the filters in tunicates, act simply as a sieve because 'smaller particles than the mesh size can be trapped if the strands of the filter are sticky'. However, this mucus net remains to be described.

\section{Gastropods}

In Gastropoda, suspension feeding seems to be confined to some pectinibranch Prosobranchia, where filtering mechanisms have evolved independently within several families, and to the pelagic shelled Pteropoda, or Thecosomata (Jørgensen 1966).

Crepidula: species of the genus Crepidula are generally considered to be suspension feeders (Orton 1915, Werner 1959, Jørgensen 1966, Jørgensen et al. 1984), but Navarro \& Chaparro (2002) found that during the motile phase of the life cycle $(<28 \mathrm{~mm}$ in shell length), Crepidula fecunda depends on both ingestion of food by grazing and by suspension feeding. The 2 feeding mechanisms seem to be related to protandry. The larger-sized specimens (females) are sedentary with little or no capacity for movement, and suspension feeding is, thus, the only mechanism available (Navarro \& Chaparro 2002).

We describe the feeding mechanism in Crepidula fornicata as an example of a mucus-net filter-feeding prosobranch. C. fornicata produces a water current through the mantle cavity by the activity of the lateral cilia of the gill filaments. The through-current passes 2 mucus filters, a coarse filter at the entrance to the mantle cavity and a fine one that is transported across the gill surface by means of the frontal cilia of the gill filaments (Fig. 17). The coarse filter is built of longitudinal and transverse mucus fibers (Werner 1953). The fine structure of the gill filter has not been studied. Jørgensen et al. (1984) found C. fornicata to retain particles $>\sim 2 \mu$ completely, whereas $90 \%$ retention was measured for particles of $1.2 \mu \mathrm{m}$ in diameter.

Pteropods: the shelled, thecosomatous pteropods are an important constituent of oceanic zooplankton (Hunt et al. 2008) and described as passive suspension feeders (Gilmer 1990) in which the capture of food particles takes place through a combination of trapping motile prey (Gilmer \& Harbison 1991) and collecting sinking particles, the latter described as 'flux feeding' (Jackson et al. 1993). Early laboratory studies of the pteropod Limacina retroversa by Morton (1954) led to the conclusion that food was derived from water drawn by ciliary action through the mantle cavity where particles were trapped on mucus secreted by the pallial gland. It was only when the first in situ observations were made, using scuba, that it became clear that all thecosomes capture food using a spherical mucus web several times the size of their body (Gilmer 1972, Gilmer \& Harbison 1986). The mucus web, most likely produced by the pallial gland, is suspended above the animal during feeding. Field observations of Limacina spp. show that the mucus web can be deployed in $\sim 5 \mathrm{~s}$ and

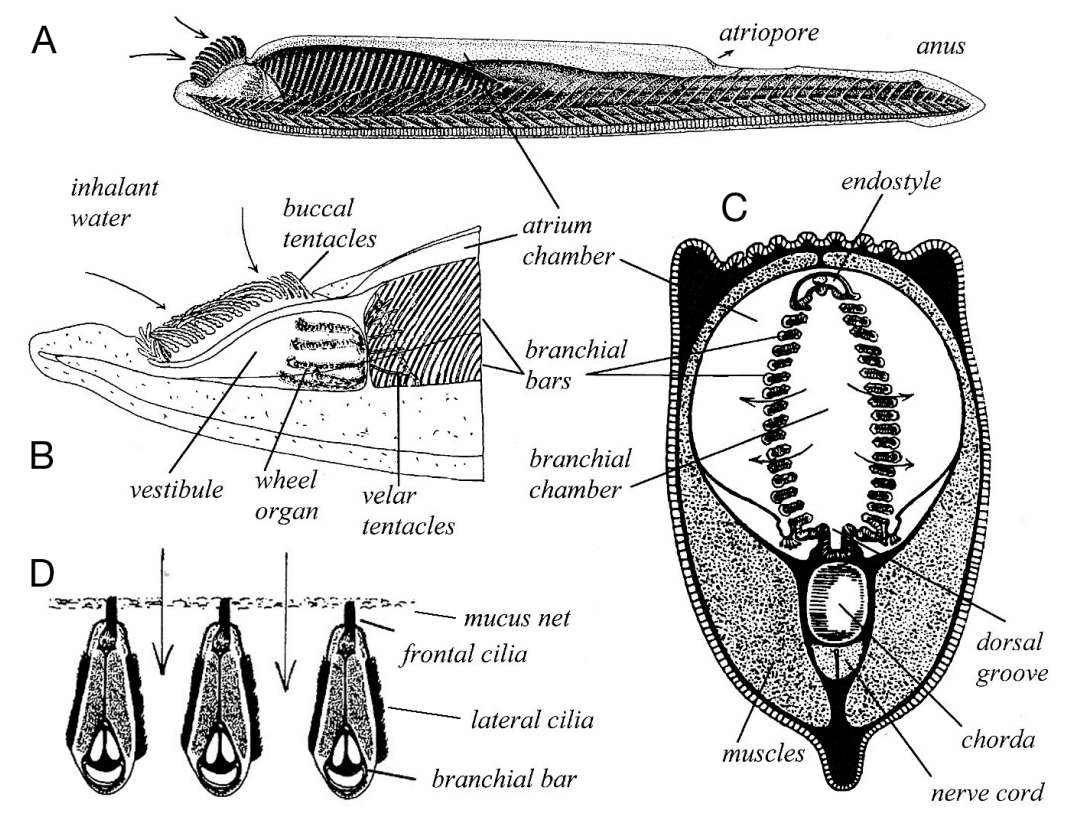

Fig. 16. Branchiostoma lanceolatum. (A-D) Outline of filter-pump design. See section 'Cephalochordates (Lancellets)' for description. From Riisgård \& Svane (1999, based on various sources) 


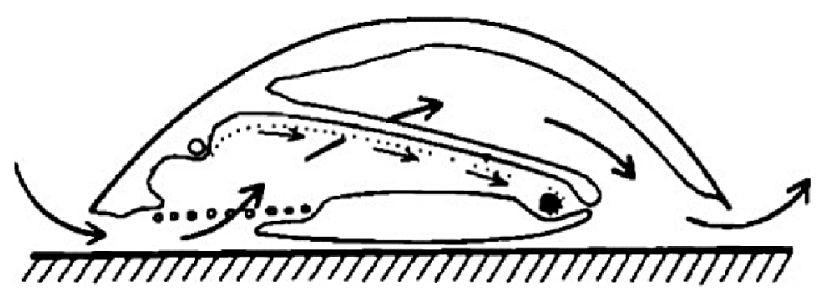

Fig. 17. Crepidula fornicata. Transverse section, indicating the coarse mucus filter at the entrance to mantle cavity (bold dots) and fine mucus filter (fine dots) continuously transported across gill and rolled up in the food groove on the dorsal side of the foot. From Jørgensen et al. (1984, based on Werner 1959)

retracted in <20 s (Gilmer \& Harbison 1986), but web production rates are still unknown (Lalli \& Gilmer 1989).

Echiurans: Urechis caupo is a large mucus-net filterfeeding echiuran worm living in a U-shaped burrow in mudflats along the Pacific coast of California. The filter-feeding behavior of $U$. caupo has been thoroughly studied under laboratory conditions (Fisher \& MacGinitie 1928, Hall 1931, MacGinitie 1945, Jørgensen 1955, Lawry 1966, Pritchard \& White 1980, Jørgensen et al. 1986, Julian et al. 2001) and in the field (Osovitz \& Julian 2002). It pumps seawater using anterior-toposterior peristaltic muscular contractions of its body wall, and the water current is filtered through a funnelshaped mucus net that is secreted by specialized glands near the worm's proboscis and which surrounds the anterior end of the body. The mucus net efficiently captures suspended particles from the feeding current. When the mucus net is loaded with food material, it is detached from the body. U. caupo moves backward and seizes the loaded net with its short proboscis and swallows the mass, after which it spins a new net and begins the filter-feeding process again.

\section{Filter setae in crustaceans}

In suspension-feeding crustaceans, some of the head or trunk appendages have developed into filtering organs, with plumate 'filter setae'. This and other general features of filter-feeding crustaceans are treated in the following sections. In selected groups, the basic filterfeeding mechanisms and principles are briefly reviewed.

\section{Branchiopods}

Most branchiopods are filter feeders that collect suspended food particles with the fine filter setae on the trunk limbs (Fig. 18). Flow is generated by the socalled 'suction-and-pressure chamber' mechanism in which the metachronically moving limbs first move apart to create a space or chamber that is filled with water, while the suspended particles are retained by the filter setae outside the chamber to end up in the ventral feeding groove, and then the limbs move back together to expel the water through a valve on the opposite side of the filter-wall. This process ensures that water is sieved by the filter setae, and the trunk limbs are self-cleaners, scraping restrained suspended food particles from the filter (Cannon 1928, 1933, Barlow \& Sleigh 1980, Fryer 1983). The anostracans (fairy shrimps) are the most primitive branchiopods; the swimming movements of the phyllopods form suctionand-pressure chambers where water is forced through the filter setae on the gnathobases (Daborn 1979, Mertens et al. 1991, Williams 2007). In the cladocerans (water fleas), the feeding mechanisms are more varied and specialized, but apparently the filter-pump mechanisms can be derived from the phyllopod suction-andpressure chamber type. In cladocerans, the shells help to form suction-and-pressure chambers. During abduction, the limbs move laterally so that the exopodites are pressed against the shells which, thus, close the suction chambers laterally; during adduction the limbs move a little medially. In the anomopods (Daphniidae), only 5 pairs of thoracic limbs are present, but all participate in the formation of suction-and-pressure chambers, and the main features in the feeding process are identical: water is sucked from the median space into the lateral suction-and-pressure chambers, and suspended particles are filtered off by the setae of the endites (Fig. 19).

The suspension-feeding process in cladocerans is generally considered to be true sieving, implying that the mesh size of the filter (i.e. the distance between setae or setules) determines the size of the suspended particles retained (i.e. the particle retention efficiency) (Gophen \& Geller 1984, Brendelberger 1985, 1991). The filtering screens are conspicuous comb-like structures on the third and fourth thoracic limbs. They are basically formed by a row of long setae, which have along their length 2 rows of setules that more or less fill the spaces between the setae, and the distance between them determines the mesh size of the screen. The fine structure of the filters is shown in Fig. 18. On each seta, 2 rows of setules are positioned at an angle of $90^{\circ}$, and the setules of one seta are linked with little hooks at their ends to the setules of the adjoining setae (Watts \& Petri 1981, Gerritsen \& Porter 1982, Brendelberger \& Geller 1985, Brendelberger 1985, Bednarska 2006). At the linking hooks, the 2 rows of setules form an angle of $90^{\circ}$ again, so that the whole filtering limb is a 3-dimensional structure. The fine structure and mesh sizes differ with different species and age stages, and the area of filtering screens and the density of setules 
vary in animals from different localities with different food conditions (Gophen \& Geller 1984, Machácek 1998, Bednarska 2006).

Many studies have examined the morphology of the filtering apparatus of cladocerans, but Brendelberger (1985) represents the first attempt to simultaneously evaluate if filter meshsizes and filtration rates for particles of different size are correlated. The study supports that the filter-mechanism is true mechanical sieving, i.e. that all particles smaller than the smallest mesh-size can pass through the filter, and that all particles larger than the largest pore-size are retained. The true sieving conception has been supported by several experimental studies and theoretically by models of fluid dynamics (Gophen \& Geller 1984, Fryer 1987 , Brendelberger 1985, 1991, Brendelberger et al. 1986, Lampert \& Brendelberger 1996). Nevertheless, it has been suggested that mechanical sieving may be an insufficient explanation of the mechanism of particle retention. Thus in Daphnia magna, according to Gerritsen \& Porter (1982), particles may be captured by the attraction of electrical charges between the particles and the filter surface (Fig. 19), and not by sieving. Ganf \& Shiel (1985) attempted to define the fluid motion associated with the setules of limbs III and IV by calculating both Reynolds number and the boundary layer, and they found it 'highly unlikely' that water could pass between the setae. Moreover, Gerritsen et al. (1988) suggested that the majority of water with suspended particles does not flow through the filter combs, but rather tangentially to them. They proposed that the filter appendages acts as paddles or 'solid walls', not sieves, and that the main mechanism for food collection in Daphina is direct interception. However, Gophen \& Geller (1984) investigated the particle size selection of 4 Daphnia species using suspended bacteria and spherical plastic beads as artificial food. The mean sizes of the filter pores were about 0.4 to $0.7 \mu \mathrm{m}$, and in all experiments the size of the particles found in the gut were larger than the smallest filter-mesh sizes; conse-
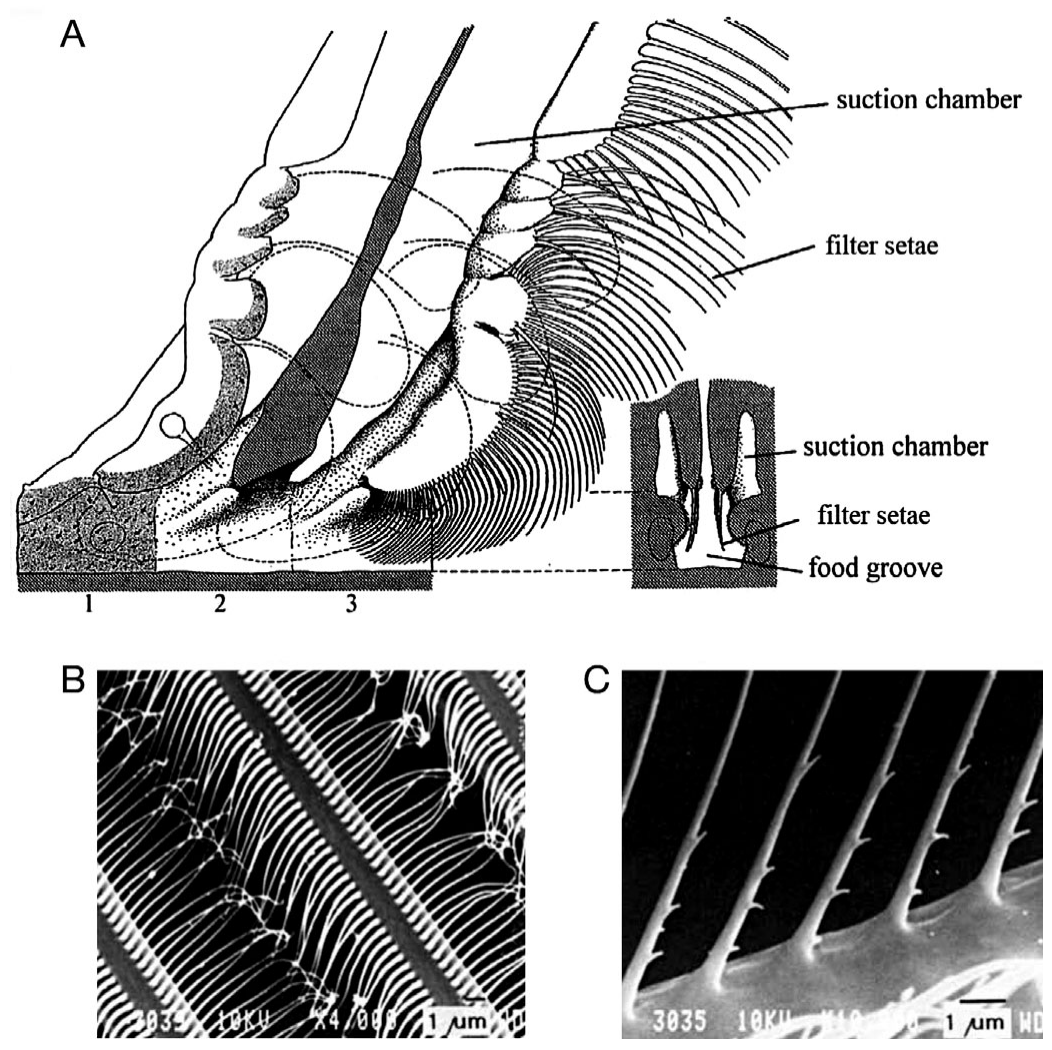

Fig. 18. Feeding appendages in fairy shrimps (Anostraca). (A) Branchinella australiensis. Median view of 3 trunk limbs with filter setae (from Cannon 1933). $(\mathrm{B}, \mathrm{C})$ Streptocephalus proboscideus. (B) Filter setae with interlocking setules, and (C) setulation. From Mertens et al. (1991)
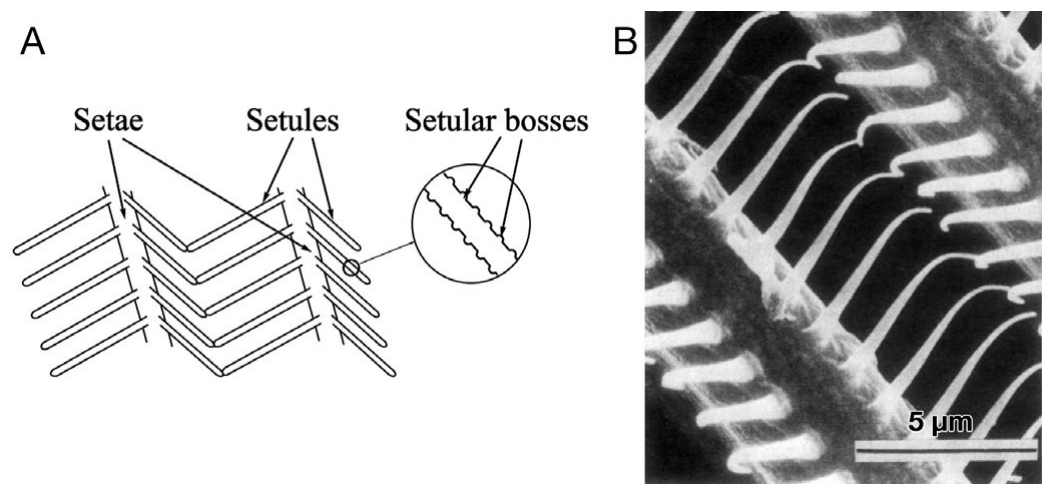

Fig. 19. (A) Daphnia spp. The filter combs attached to the third and fourth thoracic limbs are compound, 3-dimensional structures consisting of 3 levels of organization: (1) setae (basic elements of the filter screen), (2) setules (secondary structures arranged in 2 rows at an angle on the setae), and (3) setular bosses ( 2 rows of ultra fine knobs on the setules of yet unknown function). From Bednarska (2006). (B) Setulation in Daphnia magna; mean diameter of the setules = $0.4 \mu \mathrm{m}$, intersetular openings range from $0.85 \mu \mathrm{m}$ at the base to $1.25 \mu \mathrm{m}$ at the tip. From Gerritsen \& Porter (1982)

quently Gophen \& Geller (1984) concluded that 'simple mechanical sieving provides a sufficient explanation'. Furthermore, according to Brendelberger et al. (1986), the suction-and-pressure-chamber pump is able to 
provide the necessary pressure needed to squeeze the water between the setae. Thus, Brendelberger et al. (1986) estimated that the energy needed to press water through the limb filters is about $5 \%$ of the total metabolic requirements of the animal, indicating that there is 'no reason to reject the hypothesis that Daphnia collects food by sieving water through its thoracic limbs'.

\section{Barnacles}

The barnacles are filter feeders that capture plankton by means of their long feeding legs, called cirri (e.g. Southward 1955a, Crisp \& Southward 1961, Anderson \& Southward 1987, Trager et al. 1990, Arsenault et al. 2001, Marchinko \& Palmer 2003, Marchinko 2007, Chan et al. 2008, Geierman \& Emlet 2009).

Rhythmic extension and withdrawal of the cirri, formed into a 'cirri sweep net' or 'cirral fan', is typical of actively filter-feeding barnacles (Fig. 20). The long cirri are mainly used in feeding on zooplankton organisms and large phytoplankton cells. Small phytoplankton cells easily pass through the cirral fan, but such particles can instead be filtered off by short cirri that are held spread out into a fan across the entrance to the mantle cavity. When water-flow speed is increased, the adult barnacle Semibalanus balanoides changes feeding behavior from actively sweeping the cirri through the water to passively holding the cirri into the current (Fig. 20A). In slow flow, each active sweep of the cirri creates a feeding vortex that causes suspended particles to swirl into the capture zone of the following sweep.

\section{Copepods}

In copepods, raptorial feeding is probably primary, and filter feeding is a specialized condition especially developed within the calanoid copepods (Cannon 1929, Marshall \& Orr 1966, Boyd 1976, Nival \& Nival 1976, 1979, Rosenberg 1980, Koehl \& Strickler 1981, Paffenhöfer et al. 1982, Price \& Paffenhöfer 1986, Tiselius 1989, Jonsson \& Tiselius 1990, Hansen \& Tiselius 1992, Kiørboe \& Saiz 1995, Saiz \& Kiørboe 1995, Kiørboe et al. 1996, Kiørboe 1997 , 2008). However, no copepod species seems to rely exclusively on suspension feeding. In most suspensionfeeding copepods, a 'filter chamber' is enclosed between the ventral body wall and the second maxillae which carry long plumate setae that form the lateral walls of the 'filter chamber'. Four pairs of appendages produce the feeding current past the copepod. In some species, the second maxillae do not act only as passive filters, but the setae of the maxillae are alternately spread apart to form an open basket-like structure and quickly drawn together (Fig. 21). The complicated feeding processes can

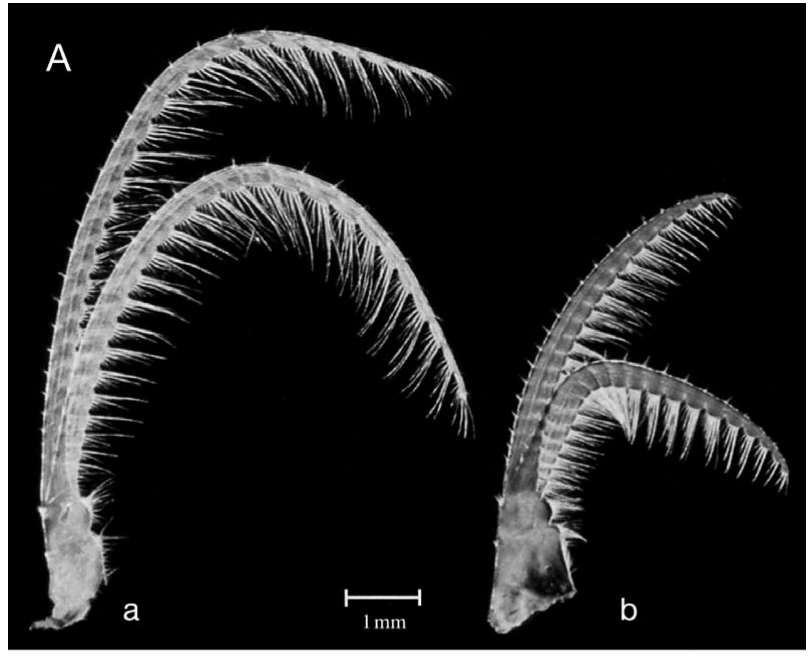

B

ACTIVE FEEDING
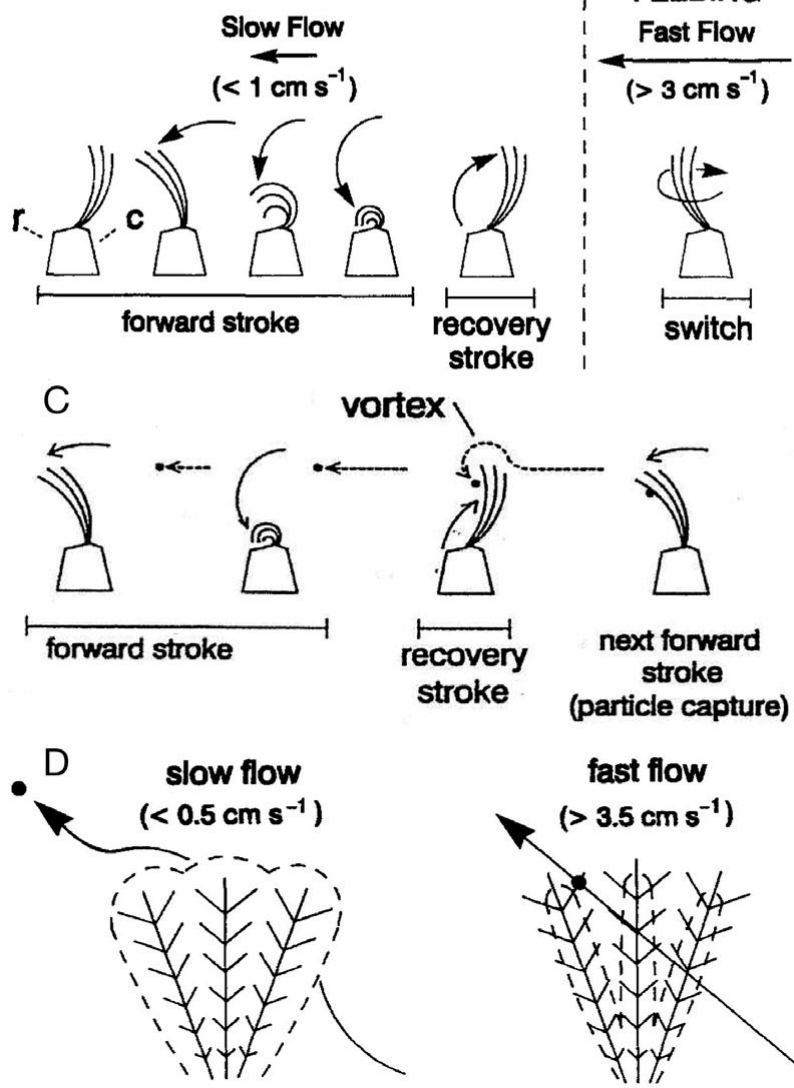

dye goes around
PASSIVE FEEDING Fast Flow $\left(>3 \mathrm{~cm} \mathrm{~s}^{-1}\right)$

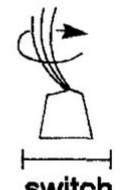

switch capture)

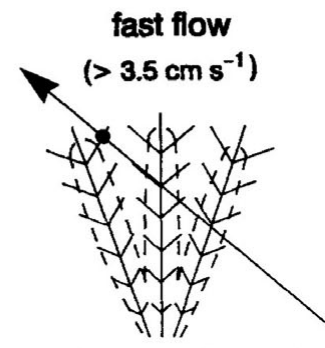

dye goes through
Fig. 20. (A) Balanus glandula. The biramus feeding legs of similar sized (same body mass) barnacles from a protected harbor (a) and an exposed outer coast (b). From Arsenault et al. (2001). (B-D) Semibalanus balanoides. (B) Active and passive feeding behavior of barnacle. r: rostral shell-plate; c: carinal shell-plate. (C) Active-feeding vortex formation and particle capture (in $0.5 \mathrm{~cm} \mathrm{~s}^{-1}$ flow from right to left). (D) Hypothetical boundary layer (dashed outlines) and water flow associated with the cirral fan at different ambient flow speeds. (B-D) From Trager et al. (1990) 


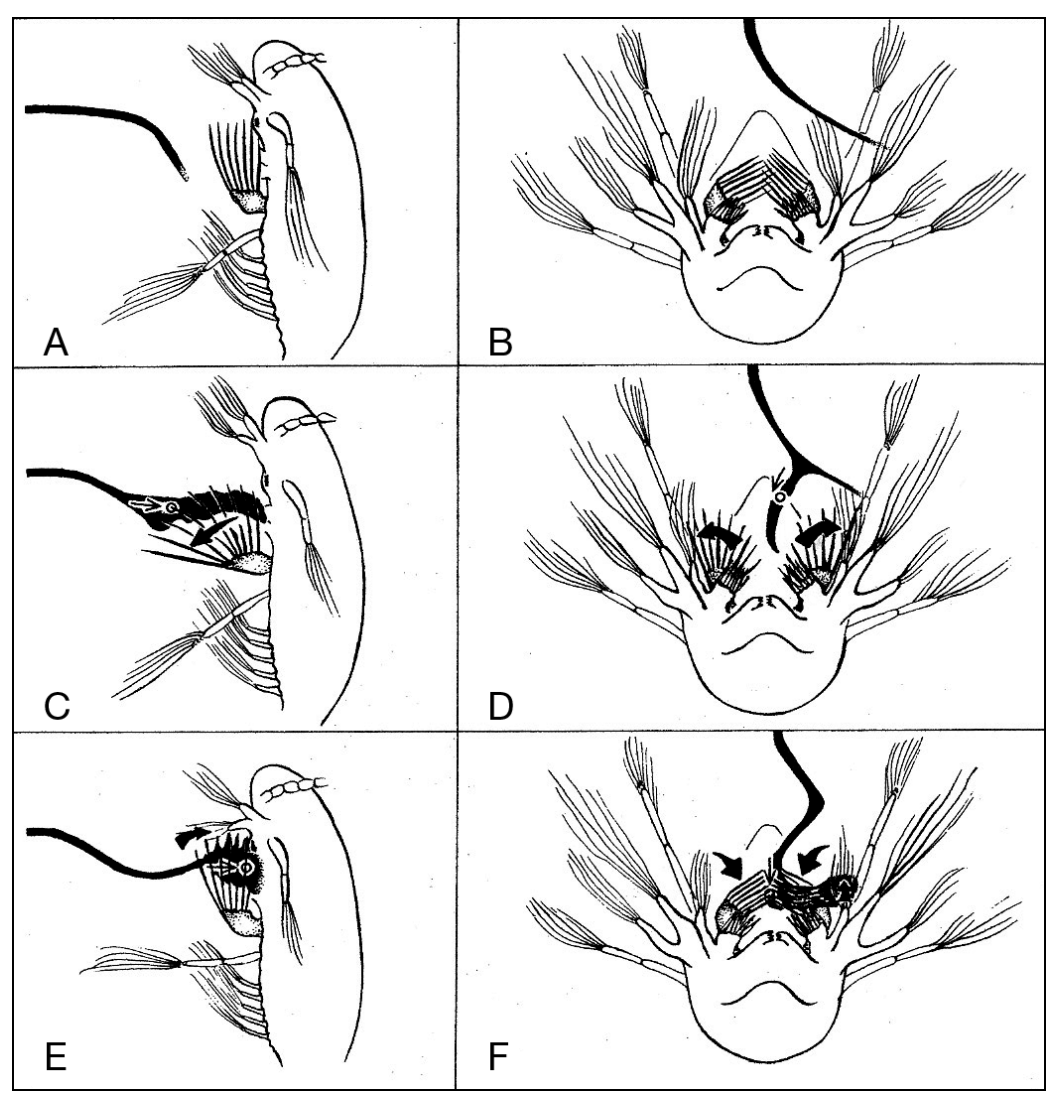

Fig. 21. Eucalanus pileatus. Diagrams traced from high-speed films of a feeding copepod. Black streaks are dye streams from a micropipette. Heavy arrows indicate movements of second maxillae (and of a first maxilla in panel F). Circles represent the positions, and fine arrows indicate the movements, of algae observed during similar appendage motions in other frames of films. The copepod is viewed from its left side and the first maxilla has been left off for clarity. (A,C,E), or from its anterior end $(B, D, F)$. Feeding currents bypass the second maxillae $(A, B)$ until an alga nears them. Alga is captured by an outward fling $(C, D)$ and an inward sweep $(\mathrm{E}, \mathrm{F})$ of the second maxillae. From Koehl \& Strickler (1981) squeeze back together. Copepods can sense incoming chemical cues from an algal cell and re-direct and capture it by asymmetrical motions of the feeding appendages. The second maxillae fling open and suck in the water parcel with the algal cell (denoted 'scan and trap' by LaBarbera 1984). The raptorial type of food capture is similar to the capture mechanism described above, but no feeding current is required and the prey is caught by raptorial seizing and holding with the second maxillae (Marshall \& Orr 1966). Some copepods (e.g. Acartia tonsa) can switch between a suspension-feeding mode in which the copepod generates a feeding current, and an ambush-feeding mode in which it sinks slowly and perceives and attacks motile prey passing within the reaction distance (Kiørboe et al. 1996, Kiørboe 1997, 2008).

\section{Euphausiaceans}

Suspension feeding in euphausiaceans (krill) is well-known as it has been thoroughly studied (Marr 1962, McWhinnie \& Denys 1980, Kils 1983, Ross \& Quetin 1983, Hamner 1988, Hamner et al. 1989, Suh \& Nemoto 1987, Suh \& Choi 1998). In Euphausia superba, the long legs with setae, and the cavity these enclose, form the 'filter basket' (Fig. 22). As the filter basket vary from species to species, as also reflected in the morphology of the second maxillae. Calanoid copepods have maxillae built on the same general plan where a varying number of long setae furnished with 2 rows of setules form the filtering screen, and the setules are usually closest at the proximal end of the limb and at the base of the setae. The water current produced by the feeding appendages in suspension-feeding copepods bypasses the second maxillae, but rather than being passive filters, the second maxillae actively capture food particles from this scanning current. During a capture, the second maxillae fling away from each other and then

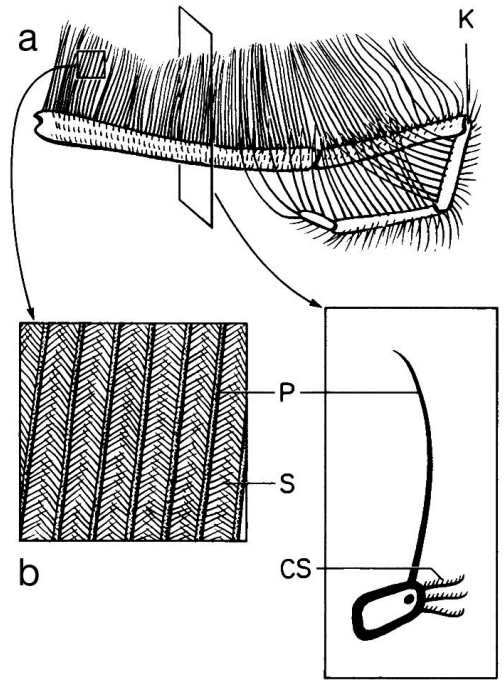

Fig. 22. Euphausia superba. (a) Second left endopodite in normal position. $\mathrm{K}=$ flexure of leg at ischio-meral joint. (b) Windows show fine structure of primary setae (P), secondary setules (S), comb setae (CS). (c) SEM-micrograph, showing tertiary setules (T). From Hamner (1988) 


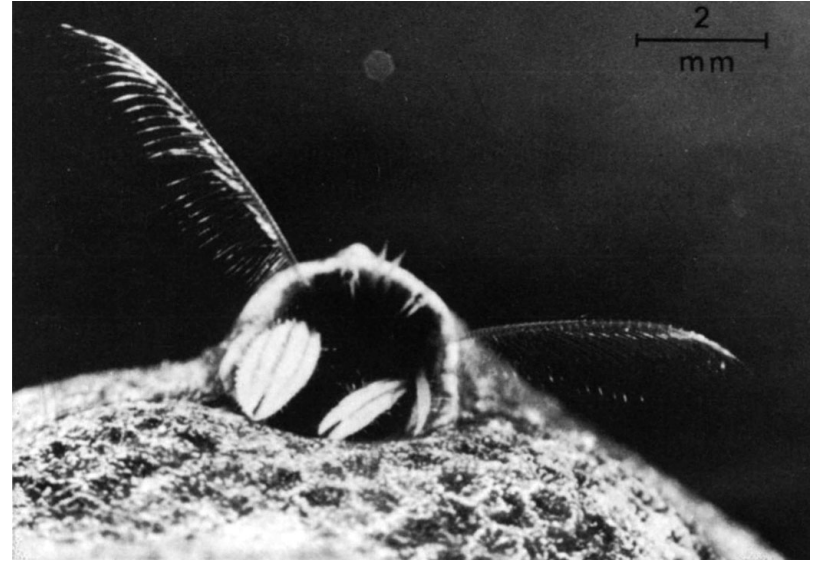

Fig. 23. Paguritta harmsi. Small hermit crab in the opening of a polychaete tube. The feathered antennae are in a position to catch plankton. From Schuhmacher (1977)

expands laterally water is sucked into the basket from the front. Once inside the filter basket, suspended particles are retained on the filter and water is squeezed out laterally between the setae. During the expansion of the basket the exopodites act as flapper valves which inhibit lateral entry of water, but during the compression stroke the exopodites lift to permit expulsion of water ('compression pumping').

\section{Decapods}

Filter feeding in decapods has been described for several species (e.g. Nicol 1932, Gerlach et al. 1976, Schuhmacher 1977, Dworschak 1981, 1987, Kropp 1981, 1986, Scott et al. 1988, Manjulatha \& Babu 1991, Miller et al. 1992, Trager et al. 1992, Loo et al. 1993, Trager \& Genin 1993, Nickell \& Atkinson 1995, Stamhuis \& Videler 1998a,b,c, Achituv \& Pedrotti 1999, Coelho et al. 2000, Valdivia \& Stolz 2006). A unique adaptation to filter feeding is found in the sessile small hermit crab Paguritta harmsi living in the calcareous tubes of a coral epibiont polychaete worm. P. harmsi depends on water currents to transport suspended food particles that are caught with the second pair of antennae which are plumose with setae and setules (Fig. 23). The sieving antennae are kept perpendicularly to the current and they can be flexed and turned to utilize currents coming from various directions. However, if the water current ceases, P. harmsi switches from passive to active filter feeding and in this mode the antennae are continuously moved forwards and backwards. When a food particle is caught by the setal filter the antenna is abruptly flexed down so that the third maxillipeds can brush out the captured particle and transport it to the mouth. Filter feeding in porcelain crabs is performed with 2 collecting fans formed by the third maxillipeds. At low flow rate, the crabs actively sweep the water with their maxillipeds, but at higher flow rate, the crabs switch from active to passive feeding. When filter feeding, the crabs perform alternate movements of the left and right feeding fans, so that one fan is extended and the concave side is facing upstream, while the other is withdrawn (Fig. 24). The hermit crab Pagurus bernhardus is able to remove both brine shrimp nauplii and suspended unicellular algae from the ambient water. To filter feed, a water current is generated by the flagella of the exopods of the second and third maxillipeds. Nauplii are caught by the grasping movements of the endopods of the third maxillipeds, whereas filtering of unicellular algae is probably achieved by the 2 maxillae. Lobsters can effectively clear water of nauplii, but low clearance rates suggest that these large decapods are not true filter feeders. In most thalassinideans, filter and deposit feeding are the 2 main feeding mechanisms. To filter feed, upogebiids produce a water flow through the Ushaped tunnel burrow by moving the pleopods. Particles suspended in this water flow are retained in the setal basket of the first and second pairs of pereiopods.

\section{Amphipods}

Some amphipods are filter feeders with different appendages adapted as collectors. The burrowing amphipod Corophium volutator feeds on organic matter on the sediment surface (deposit-feeding mode) or on suspended particles (suspension-feeding mode) by bringing these food items into its U-shaped tube in the
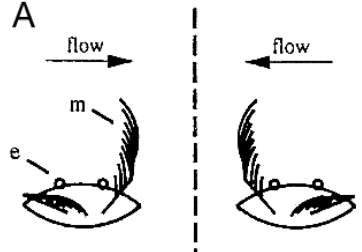

(fast oscillating flow)

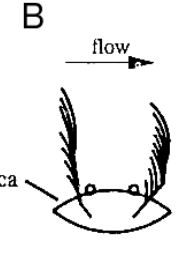

(slow oscillating flow)
Fig. 24. Petrolisthes leptochelys and P. oschimai. The porcelain crabs catch suspended food particles with their 2 cupshaped feeding fans formed by setae of the third maxillipeds. (A) In fast oscillating flow $(0.6 \mathrm{~Hz})$ the left and right feeding fan is moved alternatively so that one fan is extended and faced concave-upstream during peak velocity range of flow pulse, while the other fan is withdrawn and cleaned off. (B) In slow oscillating flow $(0.16 \mathrm{~Hz})$, however, both species move their feeding fans simultaneously so that both fans together are extended during peak velocity range of each flow cycle, and are withdrawn and cleaned off together during the low velocity range of each cycle. $\mathrm{e}=$ eye, $\mathrm{m}=$ third maxilliped, ca = carapace. From Trager et al. (1992) 
sediment (Riisgård \& Schotge 2007). When the phytoplankton concentration becomes sufficiently high, $C$. volutator switches to filter feeding by using the long setae on the second pair of gnathopods to retain suspended particles brought into the tube by the pleopodal current. A double row of plumose setae on the merus form a V-shaped filter-basket that is spread across the tube between the animal and tube wall, and periodically the second pair of gnathopods move medially while the carpal brushes of the first gnathopods brush captured particles from the filter-baskets to the mouth (Miller 1984, Riisgård 2007a). The filter is made up of fine bristles (setules) on the setae, and the distance between the bristles is $\sim 7 \mu \mathrm{m}$. The filter basket may efficiently retain particles with diameters $>7 \mu \mathrm{m}$, which has been supported by the experimentally measured particle retention efficiency (Møller \& Riisgård 2006). Riisgård (2007a) studied the integrated function of the setal filter-basket and the pleopodal pump in $C$. volutator. Video-microscope observations indicated that usually 9 short pleopod water-pumping beat cycles are followed by 1 slow cycle, coincident with the cleaning of the setal filter and a temporary slow down of the inhalant water velocity (Figs. $25 \& 26$ ). The position of the plumose setal filter on the second pair of gnathopods ensures that all water passes through the filter basket.
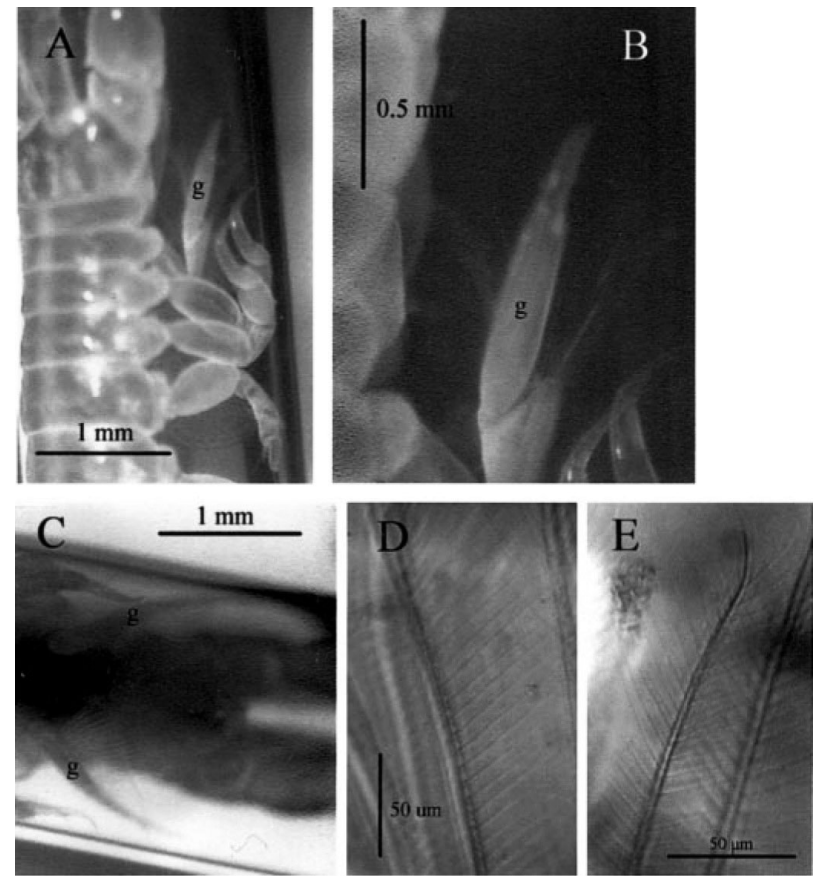

Fig. 25. Corophium volutator. (A) Dorsal view of filter-feeding amphipod in glass tube, $g=$ second gnathopod. (B) Dorsal view showing enlarged second gnathopod (g) with V-shaped setal filter. (C) Ventral view showing second pair of gnathopods (g) with setal filter. (D,E) 2 setae with fine bristles (setules). From Riisgård (2007a)
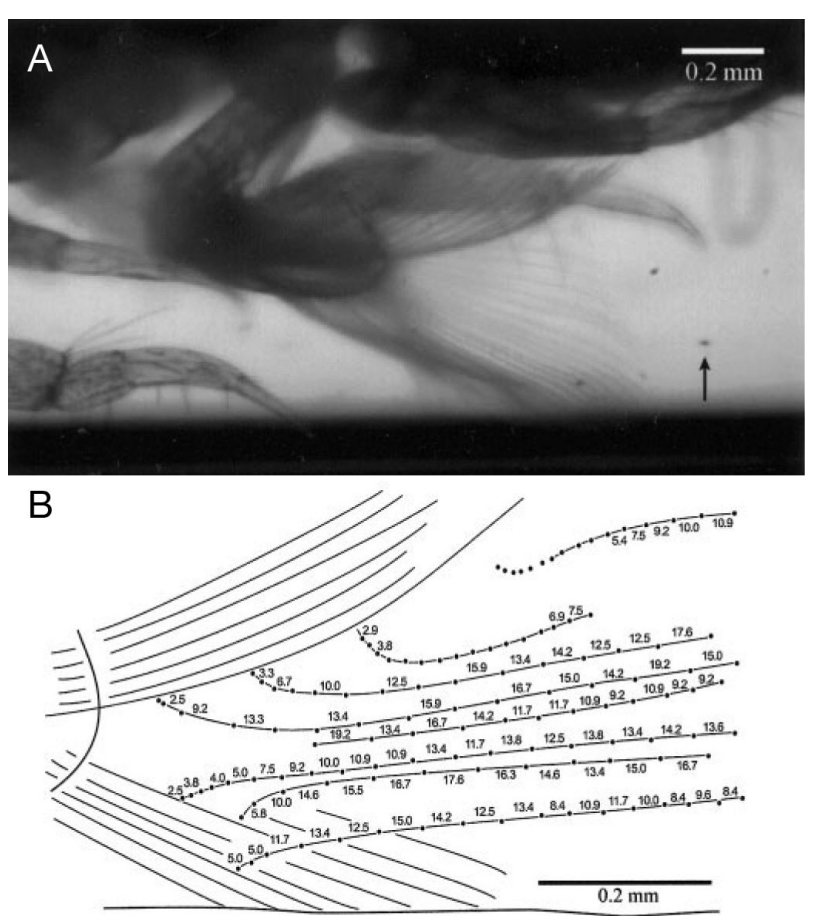

Fig. 26. Corophium volutator. (A) Ventral view of setal filter of animal in glass tube. (B) Flow lines and velocities $\left(\mathrm{mm} \mathrm{s}^{-1}\right)$ of microalgae (Tetraselmis sp.) captured on the setal filter, based on a time interval of $3.6 \mathrm{~ms}$ between successive high-speed video frames. From Riisgård (2007a)

The amphipods Dyopedos monacanthus and D. porrectus make a mast-like structure on the bottom which serves the passive suspension-feeding (Mattson \& Cedhagen 1989). Sitting near the top of the mast, Dyopedos uses its 4 antennae for sieving suspended food particles from the water current (Fig. 27). Each antenna carries 2 parallel rows of long setae which form a longitudinal furrow, the angle between the 2 rows is widened according to the strength of the current, about 90 to $130^{\circ}$. In the most common feeding position, D. monacanthus is on the upper side of the upper part of the mast. Antennae 1 are spread sideward and ventral; Antennae 2 are spread sideward and dorsal. In weak currents, the antennae may be moved slowly and independently of each other and sometimes the amphipod swings slowly from one side to the other.

\section{Non-filtering ciliary-feeding mechanism}

Several workers (Strathmann 1971, 1975, Strathmann et al. 1972, Gilmour 1985, 1986, 1988, Hart 1991) have described suspension feeding in the planktonic larvae of echinoderms. Early workers offered divergent opinions about the mechanism by which these 


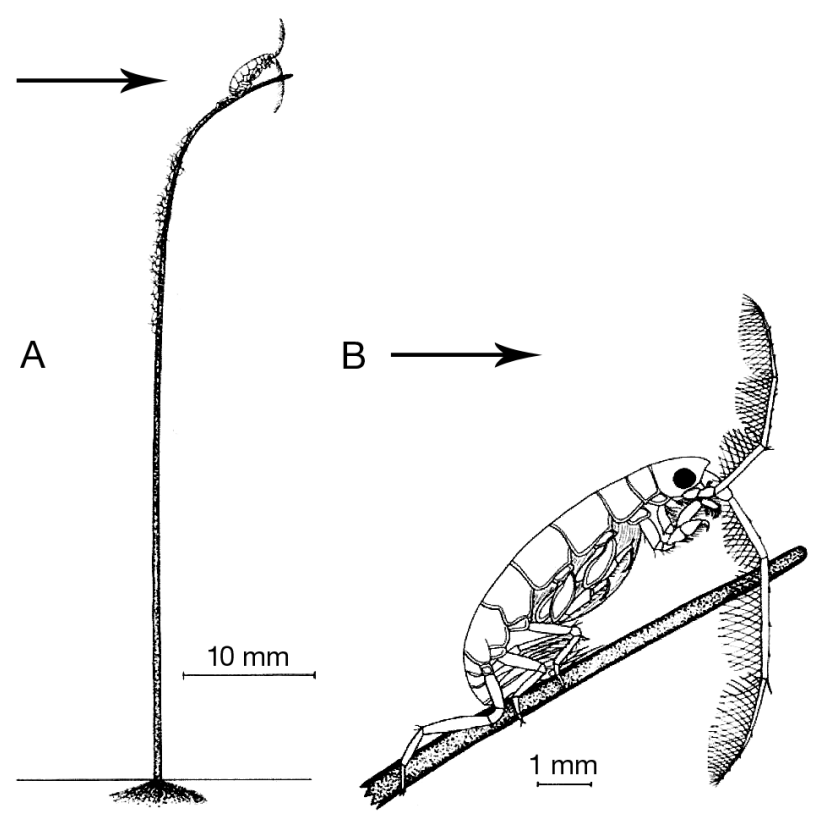

Fig. 27. Dyopedos monacanthus. (A) The suspension-feeding amphipod on its mast which enables it to reach a higher level in the boundary layer with higher water velocity. Arrows = direction of flow. (B) Detail of (A) showing the position of the amphipod's long setose antennae used for sieving food particles from the water current (left extremities are not shown). From Mattson \& Cedhagen (1989)

larvae capture suspended food particles from the seawater, but Strathmann (1971), Strathmann et al. (1972), and Hart (1991) apparently resolved many of the conflicting descriptions. Strathmann et al. (1972) suggested that local reversals of the ciliary beat of the neotroch ciliary band in early echinoderm larvae might be responsible for the particle-collecting function, which was confirmed by high-speed cinefilms of pluteus larvae. Thus, according to Strathmann et al. (1972, p. 508): 'In a feeding larva the beat is the same until a particle comes within reach of the cilia. Then an alternation of the beat of several cilia can be seen while the particle slows, changes direction, and finally is pushed back in an arc suggesting a reversed effective stroke of the cilia'. Likewise, Hart (1991) described particle captures and suspension feeding by the larvae from different echinoderm classes. The analysis of videotape recordings is generally consistent with Strathmann's description of the ciliary reversal mechanism; but Hart came up with several novel observations. Thus, the larvae appear to have 2 modes of particle capture: 'most particles are caught by apparent ciliary reversal at the ciliated band, but a small proportion of particles are captured without contacting the peripheral band' (Hart 1991, p. 14). Using high-speed video recordings in a recent study, Strathmann (2007) demonstrated that sea urchin larvae concentrate parti- cles without filtration. Thus, it was found that most of the concentration of particles occurs by a temporarily and locally redirected current — 'without filtration' and particle capture depends on sensory capabilities 'not the mechanics of filtration'-because cilia responded 0.02 to $0.06 \mathrm{~s}$ after the particle was 'within reach of effective strokes' and subsequently reversed beat for about 0.1 to $0.2 \mathrm{~s}$.

\section{Ciliary-spike suspension feeding}

Dubois et al. (2005) described the feeding mechanisms of the sabellariid polychaete Sabellaria alveolata and concluded that it is a suspension feeder which uses a ciliary system resembling that of serpulid and sabellid polychaetes. However, Riisgård \& Nielsen (2006) re-investigated both the ciliated epithelia and the function of the tentacle crown of $S$. alveolata. It was found that the tentacles of intact and undisturbed $S$. alveolata have a large number of ciliary spikes (compound cilia), which are usually kept stiff, but which may beat parallel to the length of the tentacle, each flanked by an actively beating cirrus. No structured flow of water is created and only minor local currents were seen, and $S$. alveolata does not possess a proper ciliary pump as found in truly active ciliary suspension-feeding invertebrates. This indicates that $S$. alveolata's tentacle crown is designed for passive suspension feeding and, thus, dependent on ambient currents to bring suspended food particles into contact with the tentacles. The fluid mechanical significance of the ciliary spikes remains unknown. However, the observations made by Riisgård \& Nielsen (2006) suggest that mucus is involved in both the capture and transport of food particles in $S$. alveolata, possibly in a similar way as found in spionid polychaetes (Shimeta et al. 2004).

\section{Tube-feet suspension-feeding echinoderms}

The brittle-star Amphiura filiformis feeds passively on suspended material in flowing water, but shifts to deposit feeding in stagnant water (Loo et al. 1996). In still water, it was observed that many A. filiformis extend their arms into the water, but at moderate flow velocities the proportion of individuals with at least one extended arm increases. From video recordings in flume experiments, A. filiformis was observed to capture suspended food items. Particles encountered and retained on the tube feet are transported between adjacent tube feet along the arm towards the mouth. Small papillate protrusions on the tube feet improve retention efficiency by increasing adhesion to encoun- 
tered particles. LaBarbera (1978) showed that the suspension-feeding brittle star Ophiopholis aculeata can remove particles from flowing seawater by some mechanism(s) other than simple mechanical sieving, which would exclude particles smaller than the spaces between the tube feet (i.e. $442 \pm 50 \mu \mathrm{m}$, mean $\pm \mathrm{SD}$ ). Thus, LaBarbera observed that the brittle star captured a finite proportion of artificial particles between 30 and $360 \mu \mathrm{m}$ in diameter, but the size distribution of particles caught showed a shift toward the larger particles. Therefore, LaBarbera (1978) assumed that direct interception was the predominant particle capture mechanism, in agreement with predictions derived from the aerosol filtration theory where a basic assumption is that adhesion is $100 \%$ efficient (i.e. all particles that intercept and touch a fiber adhere and are retained). Reorientation of active arms at increasing flow velocities may be an attempt to adjust the height of arm extension to match an optimal flow velocity in the boundary layer with respect to encounter rate and retention efficiency. During transport, captured particles become entangled in mucus and rolled into a bolus by the tube feet. Eventually, the bolus is transported by the tube feet below the sediment surface to the mouth. Occasionally, individuals may also pick deposited particles from the sediment surface, and this behaviour is most common in still water (Loo et al. 1996). Buchanan (1964) also observed in directional bottom-current flows that $A$. filiformis holds the arms up into the current flow with a rheotactic response to current direction and feeds by trapping suspended particles. Amphiura chiajei does not show this response and feeds exclusively on deposited matter on the sediment surface. Miller et al. (1992) found that the brittle star Amphipholis squamata in still water holds the arms on the sediment surface, but in a moderate oscillatory current, the arms are held in the flow, waving back and forth. In high flows, however, suspension feeding ceases.

Crinoids suspension feed with their feather like arms (Holland et al. 1986, Leonard et al. 1988). Feeding by the stalkless crinoid Oligometra serripinna, placed in a laboratory flume with a slow, unidirectional current of seawater, was studied by Holland et al. (1986). High-magnification video-recordings showed that each intercepted particle that contacts a single, adhesive tube foot is rapidly transferred to the pinnular food groove by a bend of the tube foot that is presumably triggered when an arriving particle is detected by mechanoreception. The tube foot bends in about $0.1 \mathrm{~s}$ and returns to its extended position in 1 to 2 s. After transfer to the pinnular food groove, nutritive particles travel to the arm axis and hence down the arm food groove to the mouth. In contrast, nonnutritive particles are discarded from the pinnular food grove where they are probably judged unsuitable by chemoreceptors 1 to $30 \mathrm{~s}$ after capture. Holland et al. (1986) argued that the fringe of tube feet (Fig. 28) does not act as a sieve because particles smaller than the gap $(63 \mu \mathrm{m})$ between the tube feet are retained. Therefore, Oligometra serripinna captures particles predominantly by the direct interception method of the aerosol filtration model that depends on the adhesiveness of the filtering elements (LaBarbera 1978, 1984).
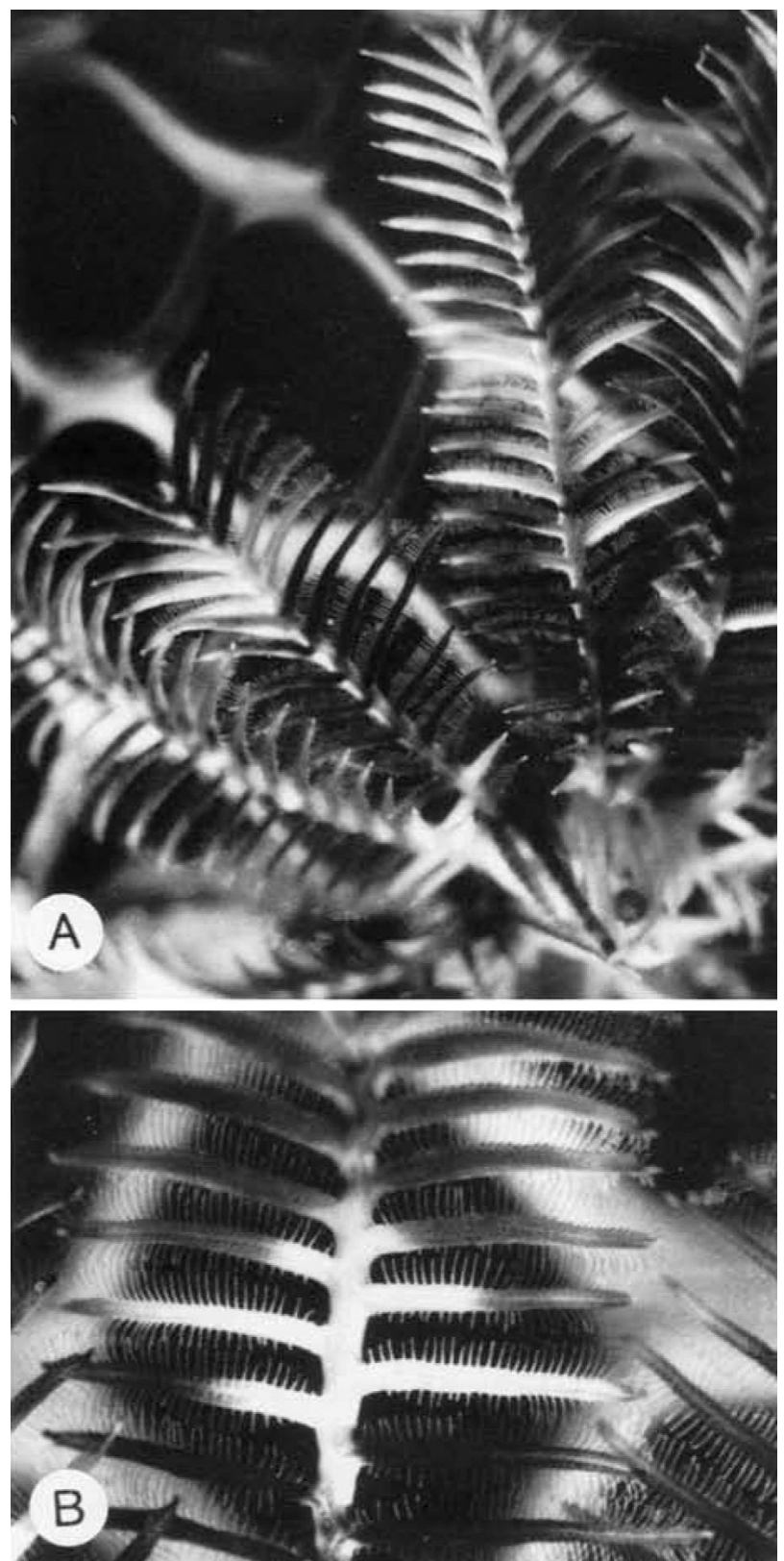

Fig. 28. Oligometra serripinna. (A) Several arms of feather star; (B) segment of single arm from which pinnules branch to right and left; each pinnule is outlined by a fringe of primary tube feet. From Holland et al. (1986) 


\section{Prey-capture mechanisms used by cnidarians}

The most conspicuous characteristic of the cnidarians is the presence of nematocysts (cnidae, 'nettle cells'). Suspension feeding has been adapted by members of the scyphozoans, hydrozoans and anthozoans.

\section{Scyphomedusae}

Feeding in jellyfish predators is characterized by selectivity, which depends on many factors such as prey size and swimming speed, predator tentacle length, width and spacing, predator swimming behaviour and resulting bell-margin water flow, nematocyst types affecting penetration of prey with different vulnerabilities to toxin and escape abilities (Costello \& Colin 1994, 1995, Ford et al. 1997, Purcell 1997, Sullivan et al. 1997, Suchman 2000).

The mechanical basis of prey capture by planktonic scyphomedusae remained largely unknown for a long time, despite the importance of these suspension-feeding predators in the sea. However, studies conducted by Costello \& Colin $(1994,1995)$ suggested that the use of umbrella pulsation-induced flow for prey entrainment and capture is widespread among the scyphomedusae, and therefore the traditional views of scyphozoan prey capture needed to be revised to include consideration of fluid motion around swimming medusae as well as prey escape responses. Until then, the subumbrellar surface (Southward 1955b), the exumbrellar surface (Bailey \& Batty 1983) and the tentacles (Fraser 1969, Heeger \& Möller 1987) had been identified as the primary body surface used to capture prey, mainly mesozooplankton, but also fish larvae, hydromedusae, and microzooplankton (e.g. Heeger \& Möller 1987, Stoecker et al. 1987, Båmstedt 1990).

Costello \& Colin (1994) examined the mechanics of prey capture by the common jellyfish Aurelia aurita using video methods to record body and fluid motions. The swimming motions of $A$. aurita can be divided into 2 phases, the power and the recovery strokes (Fig. 29).

During the power stroke, contraction of circular muscles reduces the bell diameter and water is forced out of the bell cavity in a jet directed posterior to the medusa. During the recovery stroke, the circular muscles relax, causing the bell diameter to increase so that water moves past the bell margin into the subumbrellar cavity. Prey entrained within this fluid are either sieved through tentacles lining the bell margin (Fig. 29) or directly encounter the oral arms or subumbrellar surface. These surfaces, particularly the tentacles and oral arms, are richly provided with nematocysts (Heeger \& Möller 1987) and were observed by Costello \& Colin (1994) to be the major capture sites. Prey captured on the tentacles are removed by the oral arms and passed to the gut (Southward 1955b). Costello \& Colin (1994) found that prey encounter with capture surfaces of A. aurita was presumably a function of marginal-flow velocity and prey-escape velocity. Thus, if this mechanism dominates feeding selectivity the diet of $A$. aurita would be expected to change (a)
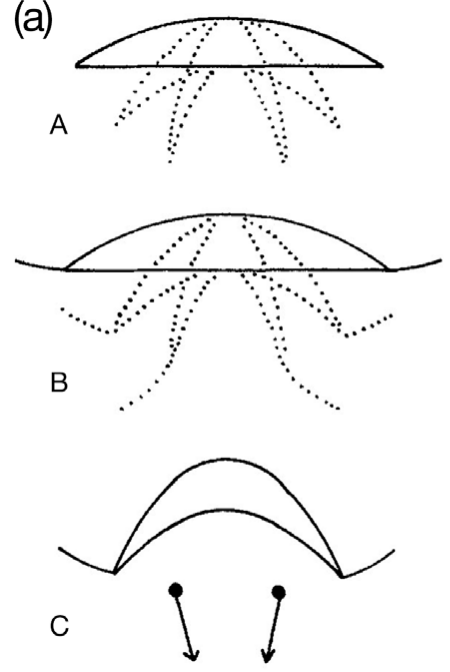
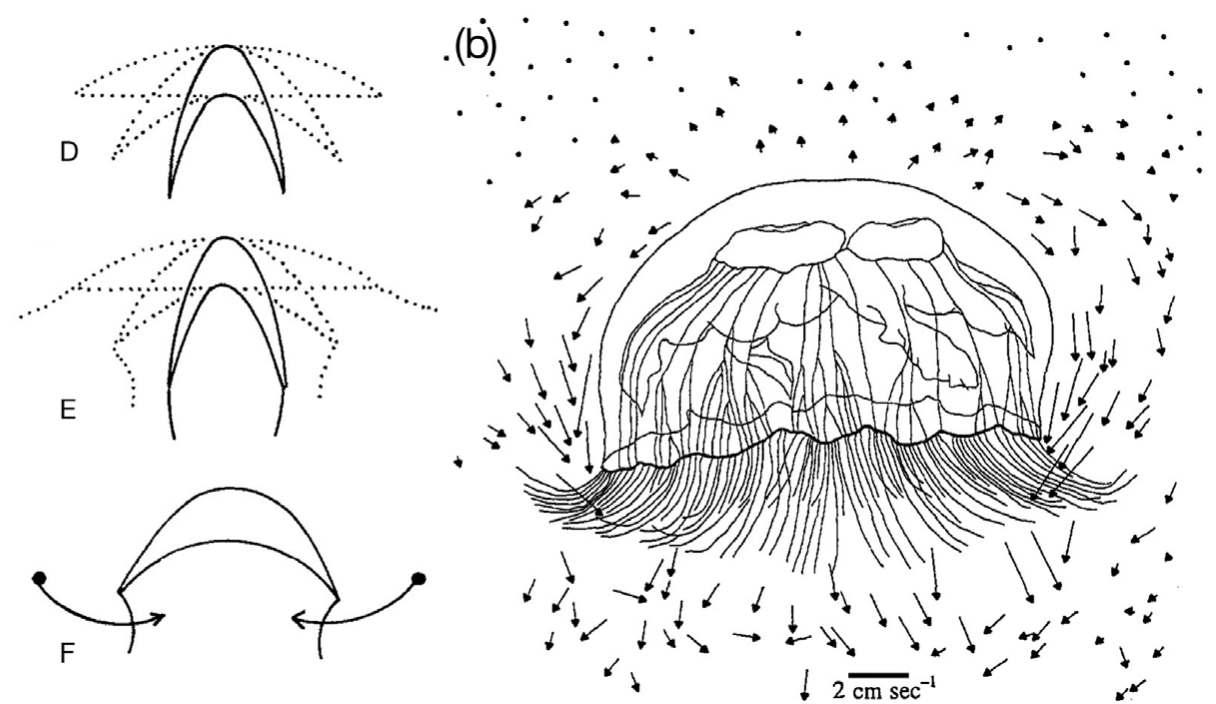

Fig. 29. Aurelia aurita. (a) Change in bell form (A) and tentacle position (B) during power stroke, motion of water and entrained particles in mid-power stroke (C), change in bell form (D) and tentacle position (E) during recovery stroke, and bell and tentacle position in mid-recovery stroke (F) showing motion of water and entrained particles (including prey). (b) Velocity vectors for tracer particles during initial stages of recovery stroke. From Costello \& Colin (1994) 
as the medusa grows because more planktonic taxa would be susceptible to entrainment in the medusan flow as bell diameter increases (Fig. 30).

The Aurelia aurita medusa begins planktonic life as an ephyra, which is typically $<10 \mathrm{~mm}$ in diameter and lacks tentacles. The $A$. aurita ephyrae capture a variety of prey (Stoecker et al. 1987, Båmstedt 1990, Olesen et al. 1994, Sullivan et al. 1994, 1997, Hansson 2006), but size, escape speed, and surface properties of prey strongly influence the capture efficiency. Thus, using video observations of free-swimming ephyrae and their prey, Sullivan et al. (1997) observed that the capture efficiencies of ephyrae feeding on large prey (barnacle nauplii, brine shrimp, hydromedusae) were 4 to 12 times greater than for small items (rotifers, copepod nauplii), and furthermore, that capture efficiencies for prey of equal sizes differed, indicating that factors in addition to size influence the predator-prey interaction: brine shrimp Artemia salina nauplii and rotifers continue to swim after entrainment and are captured more often than copepod nauplii of equal size, which cease normal swimming ('play dead'). Unlike the ephyrae, A. aurita medusae are able to capture adult copepods, and Sullivan et al. (1994) suggested that this may be due to the 'marginal-flow mechanism' of feeding used by $A$. aurita medusae (cf. Costello \& Colin 1994).

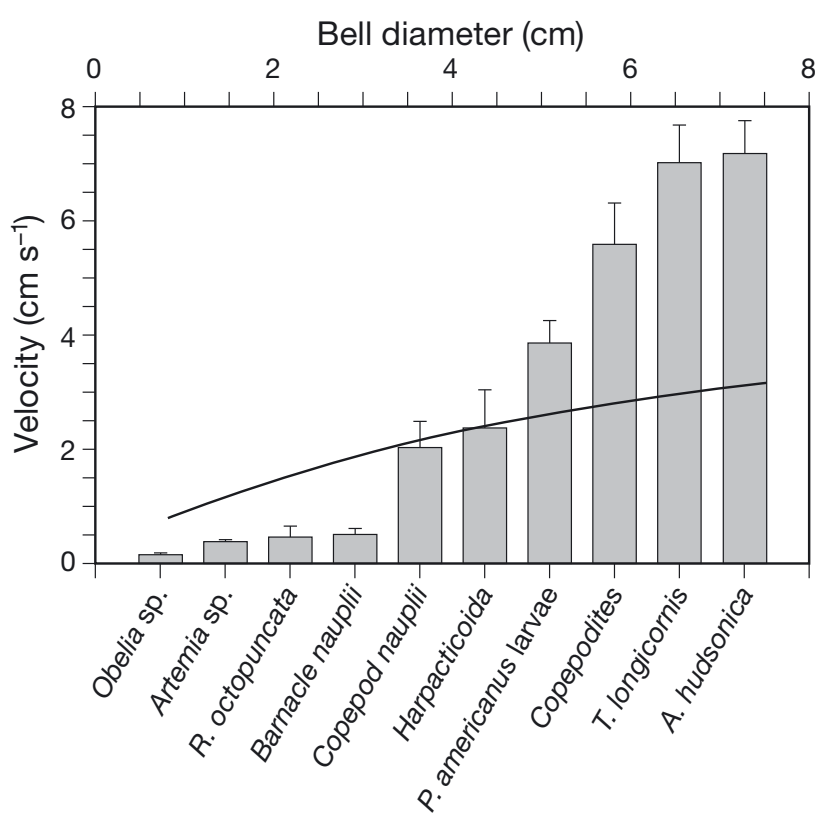

Fig. 30. Aurelia aurita. Marginal flow velocities of medusae (continous curve, top $x$-axis), and escape velocities of prey (bars, bottom $x$-axis). Hydromedusae (such as Obelia sp. or Rathkea octopuncata), barnacle nauplii, harpacticoid copepods, and other small, slow escapers are efficiently captured whereas fish larvae (Pleuronectes americanus) or adult copepods (Temora longicornis or Acartia hudsonica) have higher chances to escape. From Costello \& Colin (1994)
Costello \& Colin (1995) assessed the importance of water motion for prey capture in 3 species of scyphomedusae, representing 3 types of tentacle morphology and 3 different scyphomedusan orders. All 3 species used flow during bell pulsation to capture prey, but the type of flow used for prey capture and the capture surface morphology were different for each species. In Stomolophus meleagris (order Rhizostomeae), the oral arm cylinder (manubrium) hangs from the centre of the bell, and the active prey capture sites are multiple mouths surrounded by small, nematocyst bearing extensions of the oral arm wall. Bell contraction jets water through the capture surface, and the recovery stroke pulls prey onto the capture surfaces. In Linuche unguiculata (order Coronatae), the short tentacles are inserted between the marginal lappets, and prey entrained in the water flowing past the bell margin during the recovery stroke are captured by the marginal lappets, the oral arms or the subumbrellar wall, but not on the short non-contractile tentacles. All captures are followed by a bell crumpling response. In Cyanea capillata (order Semaeostomeae), the tentacles may be extended many body diameters behind the swimming medusa. During the power stroke, water and entrained prey is shed as a series of vortices travelling distally through the medusa's tentacles. During the recovery stroke, water is drawn inward towards the subumbrellar surface through the tentacles near the bell margin. Tentacular captures are followed by contraction of the tentacle(s) holding the prey and subsequent transfer of prey to the oral arms, where ingestion occurs (Costello \& Colin 1995).

\section{Hydromedusae}

The majority of hydromedusae are $<5 \mathrm{~mm}$ in umbrella diameter. Feeding in the small hydromedusa Aglaura hemistoma was investigated by Colin et al. (2005) using micro-videographic techniques, supplemented with gut-content analysis. Video analysis revealed that $A$. hemistoma forages as an ambush predator by floating motionless with its tentacles extended out from the bell margin (Fig. 31). A ciliary-driven current serves as a feeding current with a maximum flow velocity of $\sim 2 \mathrm{~mm} \mathrm{~s}^{-1}$ between $\sim 16$ tentacles that capture non-motile diatoms, acantharians and less motile protists (e.g. dinoflagellates or flagellates).

The feeding behavior of the ambush-feeding Sarsia tubulosa was studied by Hansson \& Kiørboe (2006) who video-observed that the capture of a copepod elicits a pronounced behavioral response involving the immediate contraction of the capture tentacle and that the mouth ingests only 1 prey at a time, but tentacles 


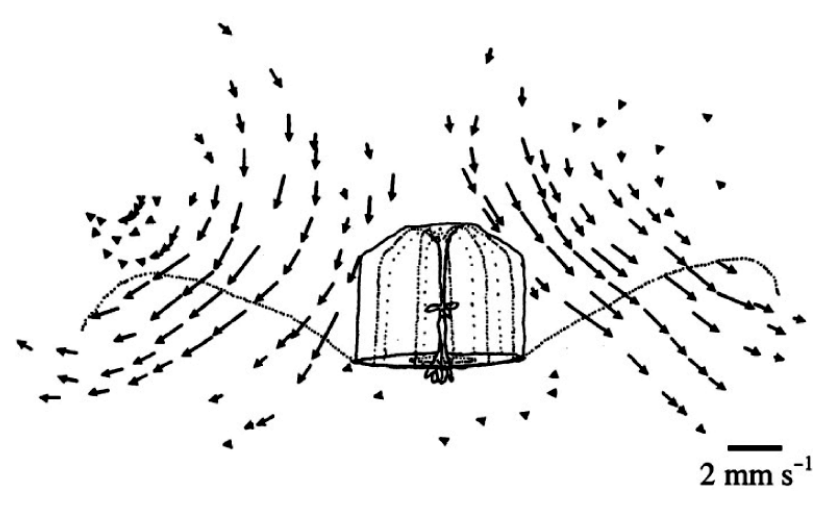

Fig. 31. Aglaura hemistoma. Flow fields generated by ciliated tentacles of the small (bell diameter $=3.5 \mathrm{~mm}$ ) suspensionfeeding hydromedusa. Only 2 of the typically 16 tentacles are shown. From Colin et al. (2005)

not engaged in food transfer may capture another prey while the mouth is busy. $S$. tubulosa medusa seems to be specialized in small crustacean prey by having tentacles with batteries of desmoneme and stenotele nematocysts that adhere to the exoskeleton of the prey (Hansson \& Kiørboe 2006).

The prey-capture mechanism of Aequorea vitrina was studied by Riisgård (2007b) using video-microscope observations. In still water $A$. vitrina remains stationary with its very long $(\sim 4 \times$ bell diameter) marginal tentacles hanging down motionless in the water, ready for ambush capture of prey organisms that collide with the tentacles. A. vitrina was found to be efficient in capturing brine shrimps (Artemia salina), less efficient in capturing rotifers (Brachionus plicatilis), and very inefficient with copepods (Acartia tonsa). The initial hauling up of an extended marginal tentacle with an adhering prey is fast $\left(>10 \mathrm{~mm} \mathrm{~s}^{-1}\right)$. Both the bell margin and the mouth move towards each other so that the captured prey can be transferred from the tentacle to the elongated mouth-lips to be further transported into the mouth and stomach. However, when A. vitrina encounters a jellyfish prey (a small medusa), it starts to swim in order to adhere the relatively big prey to its mouth-lips. Then $A$. vitrina opens up its mouth widely to swallow the captured medusa, a process which lasts about 15 to $20 \mathrm{~min}$. Field observations of $A$. vitrina revealed that the feeding behaviour was similar to that observed in the laboratory in stagnant water, and therefore it was concluded by Riisgård (2007b) that $A$. vitrina is an ambush predator. The observations indicate that $A$. vitrina is specialized in preying upon softbodied organisms and therefore lacking the sticky adhesive desmonemes (Purcell \& Mills 1988, Purcell 1997). It is unknown to what extent the ambush-predatory behavior of $A$. vitrina may be found in other Aequorea species.

\section{Anthozoans}

Anthozoans are polypoid cnidarians in which the medusoid stage is absent, such as sea anemones, corals and sea fans. The prey is caught by the tentacles, paralyzed by nematocysts, and carried to the mouth. As passive suspension feeders, the polyps are highly dependent on ambient current to drive particle-laden water past the tentacles. With increased flow velocities, more prey are transported to the tentacles, but at high speeds, mechanical deformation of the polyps may reduce the efficiency of prey capture (Patterson 1984). Thus, juvenile polyp colonies of the gorgonian Pseudopterogorgia acerosa feed most efficiently in an intermediate range of current velocities (Sponaugle \& LaBarbera 1991). This observation is supported by Sponaugle (1991) who studied the flow patterns and velocities around the tentacles using a scale model of the gorgonian polyp. Readily observable zooplankton captured by polyps has overshadowed the fact that corals do form mucus nets that capture suspended particulate matter (Lewis \& Price 1975, Lasker 1981). Thus, Roushdy \& Hansen (1961) showed that the octacoral Alcyonium digitatum is able to ingest and assimilate diatoms by means of a mucus net (Skeletonema costatum).

Anthozoans are usually assumed to be passive suspension feeders that are exclusively dependent on prey and suspended organic food particles being carried to them by a current. However, Slattery et al. (1997) observed that the colonial nephtheid soft coral Gersemia antarctica can switch to deposit feeding in the soft sediment communities of McMurdo Sound, Antarctica. Deposit feeding in G. antarctica involves bending (by means of hydrostatic inflation of the entire colony) against the sediment surface. Gut content analyses revealed a mixed diet including benthic diatoms, foraminiferans, and particulate organic matter. The depositfeeding mode in $G$. antarctica has apparently evolved to supplement the capture of planktonic prey and seems to be of particular importance in the Antarctic.

\section{Prey-capture mechanisms used by ctenophores}

Lobate ctenophores have been characterized as ambush predators that either float passively or glide slowly through the water and capture prey that swim into their outstretched lobes (Waggett \& Costello 1999). For lobate ctenophores, such as Mnemiopsis leidyi and Bolinopsis infundibulum, researchers long ago noted both the importance of cilia on the auricles for creating flow and influencing prey capture, as well as the importance of water motion for capture of prey on the oral lobes (Main 1928, Hyman 1940, Nagabhushanam 1959, 
Harbison et al. 1978, Reeve \& Walter 1978, SchulzeRobbecke 1984, Hamner et al. 1987, Matsumoto \& Hamner 1988, Matsumoto \& Harbison 1993).

The mechanisms enabling lobate Mnemiopsis leidyi to capture prey were examined in more detail by Waggett \& Costello (1999) who video-recorded the interactions between free-swimming $M$. leidyi and nauplii and adult stages of the copepod Acartia tonsa. Prey capture was observed to involve 2 different mechanisms that function simultaneously, thus explaining the ctenophore's broad range of prey. The first mechanism depends on water motion created by the beating of cilia lining the 4 auricles (Fig. 32). These cilia create a low-speed water flow into which the currentinsensitive $A$. tonsa nauplii are efficiently entrained and subsequently transported onto the tentillae. The second mechanism relies upon the collision of swimming prey with the inner surfaces of the oral lobes (Fig. 32). Adult A. tonsa are not entrained in the auricular flow, but when they sense the current they jump or swim themselves into contact with the oral lobes. In a subsequent study, Costello et al. (1999) examined the

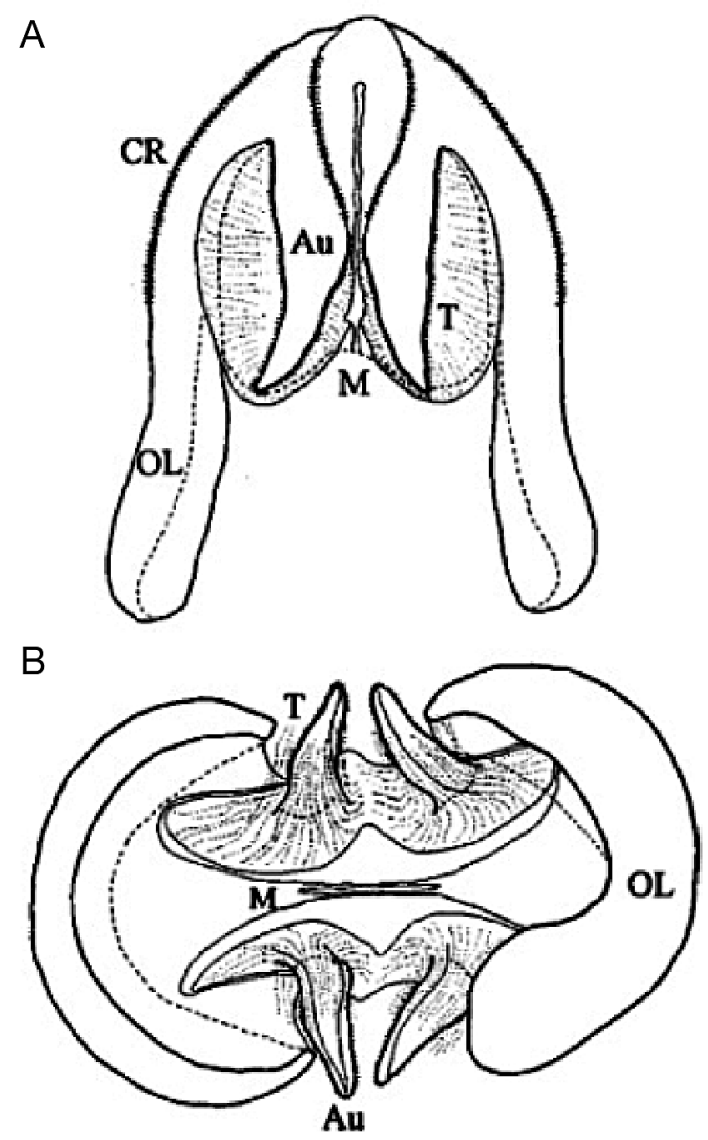

Fig. 32. Mnemiopsis leidyi. (A) Lateral and (B) oral view of lobate ctenophore. $\mathrm{CR}=$ ctene row, $\mathrm{OL}=$ oral lobe, $\mathrm{Au}=$ auricle, $\mathrm{M}=$ mouth, $\mathrm{T}=$ tentillae (oral tentacles). From Waggett \& Costello (1999)

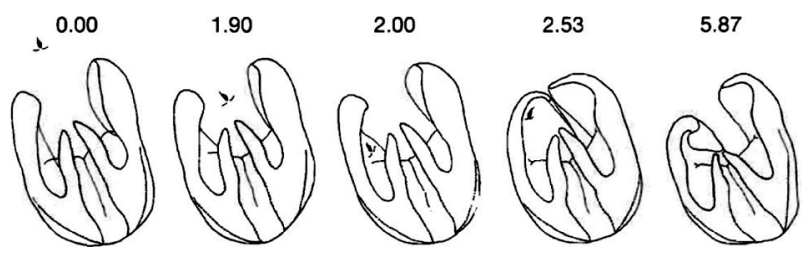

Fig. 33. Mnemiopsis leidyi. The ctenophore encounters a copepod. Successive frames (left to right) represent the time course of the encounter. Cumulative time (s) is shown above each frame. The copepod swam from the ambient water into the inter-lobe space $(1.90 \mathrm{~s})$ before jumping into the inner oral lobe surface where it was retained (2.00). The oral lobe then curled over ( $2.53 \mathrm{~s})$ and completely enveloped the prey (5.87 s). From Costello et al. (1999)

encounter process between lobate $M$. leidyi and 2 copepod species, and they observed that $\sim 50 \%$ of the encounters involved alteration of the position of the oral lobe which either preceded direct contact with a copepod or were provoked ('anticipatory responses') by fluid disturbances created by the swimming copepods (Fig. 33). After entrapment on the lobes by sticky colloblast cells (Franc 1978) or mucus, captured prey are transferred to ciliated oral grooves and transported to the mouth (Reeve \& Walter 1978).

Most research on the suspension-feeding mechanisms of Mnemiopsis leidyi has focused on the adult lobate form. But during its development the ctenophore undergoes changes from $\sim 0.5 \mathrm{~mm}$ to $>50 \mathrm{~mm}$ in length and develops from the cydippid larval stage to adult lobate stage, and this includes a shift from prey capture by means of extended tentacles during the cydippid stage to the capture of prey on the lobes by lobate individuals (e.g. Main 1928, Reeve \& Walter 1978). This transition involves a shift from a micro-planktonic diet dominated by protists to a metazoan-based diet (Rapoza et al. 2005). Cydippids feed with their long tentacles which may stretch several body lengths and possess a large number of branching tentillae off the main tentacles increasing the prey-capture surface area. Swimming prey are ensnared in the tentillae by the release of colloblast filaments. Upon prey capture, the cydippid rapidly retracts the tentacle with the captured prey, manipulating it toward the mouth, whereas the second tentacle remains extended in the fishing position (Main 1928, Reeve \& Walter 1978, Sullivan \& Gifford 2004, Rapoza et al. 2005, Waggett \& Sullivan 2006).

\section{TOWARDS AN UNDERSTANDING OF PARTICLE CAPTURE}

An improved physical and biological understanding of particle capture has emerged from the present examination of a number of species representative of 
suspension-feeding aquatic invertebrates. The physical understanding is closely related to hydrodynamic considerations, while the biological understanding must reconcile that the different groups exhibit a very wide range of morphological diversity and an impressive range of different adaptations. The capture mechanisms used may differ widely both within the same taxonomic group (e.g. mucus-net suspension feeding in certain polychaetes using either a ciliary or muscular pump, or ciliary catch-up capture in other polychaetes) and within the ontogenetic development (e.g. catch-up principle in mussel veliger larvae, but cirri trapping in the adult mussel). Yet, despite the many differences, any particle capture mechanism may be overall viewed as one of 2 types, either (1) a filtering or (2) a paddle-like flow manipulating system.

\section{Hydrodynamic considerations}

The key issue in particle capture is for a suspended particle moving with the water at some velocity relative to the organism to come close enough to the part of the organism designed for capture, such that the organism takes control of the particle. One prerequisite is, therefore, the motion of water with suspended particles relative to the organic structure involved in capture, e.g. cilia, cirri, microvilli, mucus nets, setae, tube feet. Here, either the water or structure may be at rest while the other is moving - or both may be moving; the water motion being caused by an external agent or by the organism itself. However, to distinguish between these cases has little bearing on the capture mechanism itself, but has more bearing on adaptation.

Passive and active suspension-feeders

Passive suspension-feeders rely on flow generated by ambient currents while active suspension-feeders generate the flow themselves by a suitable pump system. In a subtle way of classification, some of the former (barnacles and decapods) may switch from passive to active feeding behavior by switching to actively moving their filter structure through the ambient water at low external flow, but this can hardly be considered a pump system. Pump systems include the lateral cilia on gill filaments of suspension-feeding bivalves, tentacles of bryozoans and pinnules of certain suspensionfeeding polychaetes (e.g. Sabella penicillus, Ditrupa arietina, Euchone papillosa), cilia on either side of the stigmata in ascidians; flagella in choanocytes of sponges; limbs and appendages in copepods and other suspension-feeding crustaceans; body-undulating or piston-like movements of body segments in certain polychaetes (e.g. Nereis diversicolor, Chaetopterus variopedatus); and suction and ejection of water by 'leaf-like legs' (phyllopods) moving first apart and then back together as 'suction-and-pressure chambers' in branchiopods. Many of these pumping systems have been investigated to determine the volume flow rate, the pressure delivered to overcome the frictional pressure drop in the flow system, and the power expended by the organism (see Brendelberger 1985 and reviews by Riisgård \& Larsen 1995, 2000, 2001, 2005).

\section{Filtering}

Suspension feeding may be regarded as a step-bystep process (Rubenstein \& Koehl 1977, LaBarbera 1984, Jumars 1993, Vogel 1994, Shimeta \& Koehl 1997). The first step is particle encounter, the contact of a suspended particle with the capture device by one of several possible mechanisms: direct interception, inertial impaction, diffusional encounter, or gravitational deposition. The second step is particle retention, which is needed for the capture of an encountered particle. The retention mechanism may be the (1) trapping of encountered particles against a sieve structure (e.g. collar sieving in sponges, ciliary sieving in bryozoans and phoronids, mucus-net suspension-feeding in ascidians, setal filter-feeding in crustaceans), (2) fastening of particles with nematocysts (e.g. prey-capture mechanisms used by jellyfish and other cnidarians), (3) mucus adhesion of particles (e.g. tube-feet suspensionfeeding by echinoderms, tentaculate particle capture in spionid polychaetes), (4) electrostatic attraction of particles (which may be a possible retention mechanism in fresh water, but not in sea water which is an electrolyte). The third step in suspension feeding is transport (handling) of the captured particles to the mouth by mechanisms such as ciliary beating or motion of the particle-capturing appendage (Shimeta \& Koehl 1997).

As it appears, sieving is a means of retention rather than just one of encounter. Obviously, surface chemistry both of food particles and of sieving structures may be of great importance for retention, irrespective of the actual encounter mechanism. Direct interception works whenever streamlines come within one particle radius of the surface of a collecting structure, provided the particle follows those streamlines to make contact, and sieving is, thus, performed when streamlines converge in passing through the meshes of the sieve. This process is described by aerosol theory which considers the motion of individual particles relative to the individual elements (fibers, rods, etc.) of the porous structure and shows to what extent particles less than the 
pore-size may intercept the elements, all depending on geometry, particle size and Reynolds number. Here the case of the intermediate Reynolds number range $(0.1$ to 50) has been studied by Palmer et al. (2004) and more recently by Humphries (2009). The fraction of particles that stick when making contact is called the 'striking coefficient' (Jumars 1993). The encounter rate can be enhanced if the organisms change their feeding currents in response to the particles that they detect. The cue may be chemical (odour) or physical (sensing of a pressure disturbance) as frequently found in active suspension feeders (cf. Fig. 21). Passive suspension feeders seem more often to use direct interception, and they may, for example, position themselves in the bottom boundary layer (cf. Fig. 27) where particle concentrations and horizontal currents combine to produce high fluxes of suspended food particles.

\section{Details of the capture process}

One aspect is the geometry and physical dimensions of the structure and particle involved. Another is the possible motion of the structure and particle. Here, the fluid mechanics of low Reynolds number flows play a central role, and we note some basic phenomena of encounter.

(1) A single cilium (diameter $\sim 0.2 \mu \mathrm{m}$ ) may intercept and directly contact a particle (diameter 2 to $10 \mu \mathrm{m}$ ) moving with the fluid and stick to it due to surface forces and subsequently move the particle to a key location for further transport to ingestion, as illustrated by the recent high speed video-recordings of Romero et al. (2010). Despite the small Reynolds number $\left(\sim 10^{-4}\right.$ at relative velocity of $\sim 1 \mathrm{~mm} \mathrm{~s}^{-1}$ ), the extent of flow diverted around the thin cilium is so small that a 2 to $10 \mu \mathrm{m}$ diameter particle would not be deflected and would readily impact the cilium, if in its path. As another example, one, or perhaps a couple, of isolated stiff laterofrontal cilia on the tentacles of bryozoans have been observed to stop particles about to be lost in the flow between tentacles. This event triggers a tentacle flick — or a temporary localized arrest of the lateral pump cilia, or a ciliary reversal - which brings the particle back into the central water current directed towards the mouth. In terms of aero- or hydrosol theory we have here the unusual situation of a flow with a large suspended object (particle) approaching a very small fixed object (cilium), hence impact is highly likely.

(2) Large structures in an unconfined flow (e.g. compound cilia, hairy appendages) can usually be treated as small screens or paddles with only small leakiness (Cheer \& Koehl 1987, Koehl 1995) hence most fluid is diverted around the structure. An approaching particle may be stopped if near the stagnation streamline, and then move with the structure, or more likely it may be diverted around the structure along with a certain fluid volume ('fluid parcel') (Mayer 1994, Riisgård et al. 1996). Direct contact would be expected for very leaky structures that are large compared to the particle. But such contact and sticking appear not to have been observed.

(3) Large structures in a confined flow (mucus nets in a duct, microvilli in choanocytes, setae lining a 'suction-pressure chamber') imply a flow forced through a screen. That is, a true sieving process in which all particles will be retained if greater than some minimal diameter determined by aerosol filtration theory, which takes into account particle size relative to the diameter and spacing of cylindrical wires in the mesh. In most cases, scales of relative velocity and physical length are small enough to ensure creeping flow at Reynolds number $(\mathrm{Re}) \ll 1$, but there are cases of $\operatorname{Re}>1$ for which Humphries (2009) has shown that encounter rates of particles increase significantly above those predicted by traditional aerosol theory based on creeping (laminar) flow.

(4) Food particles usually have densities that deviate little from that of the surrounding water, hence they flow with the current in which they are suspended with negligible drift (relative velocity). So, if a suspended particle moving with a given current is to be moved out of the current, this requires an external force acting on the particle which, for steady motion at a low Reynolds number, equals the Stokesian drag force. The resulting motion of the particle relative to the current implies that an associated volume of fluid (a 'fluid parcel' larger than the particle) will move with the particle. This explains how a paddle (cirri or appendage) moving relative to a fluid current may move a fluid parcel, including a particle, out of the current, for example into another current, a capture process denoted 'scanand-trap' in calanoid copepods (LaBarbera 1984), and 'catch-up' in ciliary downstream collectors (Riisgård et al. 2000). Such features are typical at low Reynolds numbers where the viscous length (the ratio of kinematic viscosity to velocity) is large so that a disturbance from a moving object, such as a paddle or appendage, is felt at a considerable distance. Raptorial feeding on motile prey therefore occurs a high Reynolds number leaving little time for the prey to escape the predator as described by the fluid dynamics of attack jumps of ambush feeding copepods by Kiørboe et al. (2009).

(5) The interaction of several steady or unsteady local currents is complex and not well understood, but may be implemental in the transfer of a fluid parcel with a particle from one stream to another, as suggested for particle capture in the gill of the scallop Aequipecten opercularis (Riisgård \& Larsen 2005).

The foregoing basic flow phenomena are thought to be important in order to understand the different 
particle capture mechanisms (see also the early discussions by Rubenstein \& Koehl 1977, Jørgensen 1983, LaBarbera 1984, Strathmann 1987, Shimeta \& Jumars 1991, Koehl 1995, Shimeta \& Koehl 1997). In the following we provide supplementary comments to some of the mechanisms covered in the review, now based on biological considerations.

\section{Biological considerations}

Biological factors include the surface properties and nature of particles that may or may not be food, evolutionary adaptation to the environment and food availability, the metabolic cost of capture method depending on particle size, and the speed of capturing devices for motile food particles.

\section{Particle quality}

It has long been known (e.g. Kiørboe \& Møhlenberg 1981, Jørgensen 1990) that particle quality is sensed on the labial palps of mussels, a process that contributes to sorting and rejecting non-food particles. It is less well known if surface chemistry and sensing plays a role in the capture process itself. Ward \& Shumway (2004) have surveyed the literature on particle retention in suspension- and deposit-feeding bivalves. Although it is widely accepted that particle size is an important parameter that affects capture efficiency, qualitative factors can also influence particle capture, such as stickiness, electrostatic charge or muco-polysaccharides, i.e. possible interactions between the extracellular matrix of living cells and cilia and/or mucus of the bivalve gill filaments. This topic is an area of ongoing research (Espinosa et al. 2009) that perhaps also explain the apparent sticking of caught-up particles to cilia observed by Romero et al. (2010).

\section{Switching feeding behavior}

Classification of feeding types into deposit and suspension feeders is frequently used, although it has become clear that some organisms are capable of using both of these feeding methods. Biological adaptation to the changing availability of suspended food particles in strongly variable benthic environments is illustrated by the ability to switch between deposit- and suspension-feeding modes among 'facultative' suspension feeders (Riisgård \& Kamermans 2001). Another switching feeding behaviour is found in both actively and passively suspension-feeding polychaetes and crustaceans. For example, a variety of polychaetes represent- ing some spionids, nereids, fabricine sabellids, and oweniids possess such an ability (Fauchald \& Jumars 1979), as does the polychaete Lanice conchilega (Buhr \& Winter 1977). Likewise, the amphipod Corophium volutator is able to switch from a suspension-feeding mode to a deposit-feeding mode when the phytoplankton concentration comes below a certain trigger level (e.g. Riisgård \& Schotge 2007). Barnacles can switch between an active suspension-feeding mode in slow ambient water flow and a passive suspension-feeding mode in fast flow (Trager et al. 1990). Copepods can sense incoming chemical cues (odour) from an algal cell and re-direct and capture it, and some copepods can switch between an active suspension-feeding mode in which they generate a feeding current and an ambush feeding mode in which the copepod sinks slowly and perceives and attacks motile prey (e.g. Kiørboe 1997, 2008).

Another type of feeding mode switch is observed in the branchiopod Branchinecta ferox, which is an herbivore suspension-feeder until it attains a length of about $18 \mathrm{~mm}$, whereupon it transforms into a carnivore to further gain in body size (Fryer 1983). It is striking that suspension feeding, where phytoplankton is the main food source, is only found in micro-crustaceans (e.g. branchiopods, cladocerans, copepods, ostracods), while suspension feeding - where zooplankton forms an important or main part of the diet - is restricted to relatively small crustaceans (e.g. krill, mysids, cirripeds). Suspension feeding in crabs and other larger decapods is of minor importance and restricted to the capture of nutrient-rich zooplankton. It is tempting to suggest that the omnipresent use of filtratory setae in the sieving process may determine the ultimate body size that a suspension-feeding crustacean can obtain. While the body mass (and thus respiration) is likely to increase with the cube of the body length, the area of the setal filter (and thus filtration rate and food intake) is likely to increase only with the square of the body length (Humphries 2007). A tendency toward a built-in mismatch between respiration and filtration rate that increases with increasing body size may thus be decisive for the upper body size that a suspension-feeding crustacean can gain. Such considerations may be important for understanding the principles governing the evolution of herbivorous versus carnivorous particle capture mechanisms in all suspension-feeding invertebrates.

\section{Energetic cost of particle capture}

Without attempting to review the energy costs in all of the various particle capture processes, one of these (sieving) deserves attention because diet is related to 
filter pore-size which, in turn, is related to the pressure drop for a given flow rate through the filter, and pumping power is the product of flow rate and pressure drop. Thus, depending on the size of the animal, there must be an optimum filter arrangement which balances the energy used in pumping against the energy gained from the captured food (Riisgård \& Larsen 1995, 2000). True active suspension-feeding in herbivorous crustaceans is only found among small species such as cladocerans, copepods, amphipods and euphausians which are characterized by highly efficient, fine setal-setule filters which retain suspended particles down to few micrometers, or smaller. They all have developed some kind of a pressure filter-chamber, and they use muscular power to generate the necessary pressure to sieve the water. The larger crustaceans, however, employ more open setal filters that offer less resistance to the flow at higher velocities, and their diet consists of larger zooplankton prey to meet their need of more food for a reasonable energy expenditure.

A theoretical estimate of the increase in area of an efficient seta-setule filter relative to body size in order to match the need for more food would result in a monstrous and physically impossible filter (Humphries 2007), unless other factors come into play. Using computational fluid dynamics, Humphries (2009) examined the encounter rates at Reynolds numbers in the 'intermediate' range of 0.1 to 50 , and showed that the usual assumption that viscosity is dominant in suspension feeding may lead to a large underestimation of particle encounter rates. Humphries' extension of the aerosol theory has, therefore, implications for our understanding of the filter design in suspension feeders, which may capture food particles 'at rates up to 5 times higher than expected'-provided the filter design ensures flows at higher Reynolds numbers.

\section{Motile prey}

Carnivorous suspension feeding in e.g. the common jellyfish Aurelia aurita predominantly takes place during the umbrella recovery stroke, where the ambient water moves past the bell margin so that prey entrained within this water are sieved through the nematocyst-covered tentacles lining the bell margin. This mechanism is decisive for prey-capture efficiency and selectivity because more zooplankton taxa with well-developed escape mechanisms are susceptible to entrainment in the medusan flow as umbrella diameter, and thus water speed through the tentacle sieve, increases. In active suspension-feeding jellyfish such as $A$. aurita it is crucial that the marginal flow velocity is higher than the escape velocities of the prey organisms, which may be up to about $7 \mathrm{~cm} \mathrm{~s}^{-1}$ in adult copepods (Costello \& Colin 1994).
Suspension-feeding bivalves are important grazers on phytoplankton, but little is known about their ability to capture actively moving zooplankton. Green et al. (2003) studied the escape responses of copepod nauplii in the flow field of the blue mussel Mytilus edulis, and their results indicate that the mussel 'may capture and ingest at least some copepod nauplii' because nauplii are frequently unable to detect in time the relatively weak suction (escape signal) in the broad inhalant opening.

\section{CONCLUDING REMARKS}

As evidenced in the present review, many of the particle capture mechanisms are complex and not fully understood, despite several decades of intense research using theoretical and computational analyses and advanced experimental techniques - notably high speed micro-video recordings. The complexity is foremost due to the unsteady and 3-dimensional nature of the flow carrying suspended particles and driven by beating cilia or appendages. Although the creeping flow approximation associated with the low values of the Reynolds number leads to simplifications, the morphological geometries are extremely complicated and involve many moving boundaries that themselves are often influenced by the viscous flows generated. Over the years there have been many analytical and computational studies of flows relevant for suspension-feeders. Flow generated by beating cilia is quite well understood as represented by the envelope model (Blake 1971), where a waving extensible surface of large extent drives the motion, or by the sublayer model (Blake 1972), where each cilium is modeled by singularities appropriate for low Reynolds number Stokes flow. The method has been refined by many workers and used to model 3dimensional flows in complex, fixed geometries, e.g. to determine the feeding currents in encrusting bryozoan colonies (Grünbaum 1995) and other cilia-driven flows (Grünbaum et al. 1998, Gueron \& Liron 1992, Gueron \& Levit-Gurevich 1998). Singularities have also been used to approximately model unsteady ciliary action, bounding surfaces, and a finite-sized spherical particle to represent the catch-up concept (Mayer 2000). The swimming of micro-organisms in their many generic forms was recently summarized by Lauga \& Powers (2009), and the detailed complex flow about a whole copepod in various modes has been computed (Jiang et al. 2002). These few examples show that progress is being made, although so far with little contribution to the area of particle capture, other than that of aerosol theory already mentioned. 
To close this review, it is appropriate to mention some areas in need of further investigation by means of computational modeling and observations in the laboratory or field. It would be of considerable interest to compute and map the unsteady, 3-dimensional flow near the entrance to the interfilamental canals in the mussel Mytilus edulis that result from the alternate beat of opposing laterofrontal cirri in the through-flow generated by the water-pumping lateral cilia. Such results would help to clarify if particle transfer to the current generated by the frontal cilia by the cirri trapping mechanism always involves particle contact with the cirri, or if takes place further upstream due to the unsteady perturbations of the oncoming flow caused by the cirri beat. The solution of this problem would also explain the motion of an essentially neutrally-buoyant particle suspended in a fluid that is in non-uniform motion. This concerns the concept of 'a fluid parcel with a particle' being diverted by the action of cilia or cirri from one current to another. Also, once a particle has been transferred to the current generated by the frontal cilia on the gill filament, a fluid mechanical description and model is needed that explains if the particle can be kept in this confined local current without the intervention of mucus. Likely, the fluid in the current is fed by part of the main flow approaching the gill filaments as driven by the lateral cilia pumps and influenced by the additional currents generated by the laterofrontal cirri, and the velocity gradient in the frontal current may play a role in keeping the particles near the beating frontal cilia, as known from the study of the equilibrium position of a particle in laminar flow in a tube (Happel \& Brenner 1965, p. 298). This problem, which may be approximated by a steady, 3-dimensional flow, appears not to have been solved and could resolve if mucus needs to be involved in the transport, but it could also be studied experimentally by manipulating surface properties of particles.

The several observations of local cilia beat reversal or arrest (bringing about particle collection in the neotroch in early echinoderm larvae, or preventing particles from escaping between tentacles in the lower part of the lophophore of bryozoans) could be analyzed quantitatively to determine the extent and duration of the cilia involved. Between 2 tentacles of an ectoproct, for example, the lateral cilia pump water from the lophophore, which would imply a higher pressure outside than inside. Consequently this higher pressure would drive a local backflow through a short stretch with inactive cilia, thus, forcing a detected particle back into the lophophore. On the other hand, if cilia arrest and local backflow were to prove insufficient to force back a particle, it would imply that reversed cilia beat in fact occurs.
Additional flow problems may readily be formulated, and with advances in computational fluid mechanics, future modeling may, along with high-speed video microscope observations, micro-PIV techniques, and manipulation of particle surface properties and water chemistry, further improve our understanding of the capture mechanics in suspension-feeding invertebrates. Field studies, although difficult and costly, are also important. Only direct scuba observations of live, undisturbed pteropods in their natural habitat lead to the discovery that these animals use a large unsupported mucus net for capturing food particles (Gilmer 1972), and it should be kept in mind that many other extremely fragile gelatinous zooplankton organisms can only be studied by means of non-invasive methods, such as ROV (remotely operated vehicle) videorecordings. Future studies in e.g. the deep-sea using advanced diving and video-recording techniques may reveal new suspension-feeding species, possible with hitherto unknown particle capture mechanisms. On a larger scale, the interaction of fluid mechanics of various capture mechanisms, water-processing rates, and availability and composition of suspended food particles play an important role in aquatic ecosystems

Acknowledgements. A number of anonymous reviewers, and one who waived anonymity (Peter G. Beninger), have passed critical and constructive comments on this paper. Figures are reproduced by permission; we particularly thank those organisations that waived reproduction fees.

\section{LITERATURE CITED}

Achituv Y, Pedrotti ML (1999) Costs and gains of porcelain crab suspension feeding in different flow conditions. Mar Ecol Prog Ser 184:161-169

Acuña JL, Deibel D, Morris CC (1996) Particle capture mechanism of the pelagic tunicate Oikopleura vanhoeffeni. Limnol Oceanogr 41:1800-1814

Alldredge AL (1977) House morphology and mechanisms of feeding in Oikopleuridae (Tunicata, Appendicularia). J Zool 181:175-188

Anderson DT, Southward AJ (1987) Cirral activity of barnacles. In: Southward AJ (ed) Barnacle biology. Crustacean issues 5. Balkema AA, Rotterdam, p 135-174

Arsenault DJ, Marchinko B, Palmer AR (2001) Precise tuning of barnacle leg length to coastal wave action. Proc Biol Sci 268:2149-2154

Atkins D (1932) The ciliary feeding mechanism of the entoproct Polyzoa, and a comparison with that of the ectoproct Polyzoa. Q J Microsc Sci 75:393-423

Bailey KM, Batty RS (1983) A laboratory study of predation by Aurelia aurita on larval herring (Clupea harengus): experimental observations compared with model predictions. Mar Biol 72:295-301

Båmstedt U (1990) Trophodynamics of the scyphomedusae Aurelia aurita. Predation rate in relation to abundance, size and type of prey organism. J Plankton Res 12:215-229

Barlow DI, Sleigh MA (1980) The propulsion and use of water currents for swimming and feeding in larval and adult Artemia. In: Persoone G, Sorgeloos P, Roels O, Jaspers E (eds) The brine shrimp Artemia. Universa Press, Wetteren, 
p $61-73$

Barnes RD (1964) Tube-building and feeding in the chaetopterid polychaete Spiochaetopterus oculatus. Biol Bull 127:397-412

Barnes RD (1965) Tube-building and feeding in chaetopterid polychaetes. Biol Bull 129:217-233

Barrington EJW (1958) The localization of organically bound iodine in the endostyle of Amphioxus. J Mar Biol Assoc UK $37: 117-126$

Baskin DG, Detmers P (1976) Electron microscopic study on the gill bars of amphioxus (Branchiostoma californiense) with special reference to neurociliary control. Cell Tissue Res 166:167-178

Bednarska A (2006) Adaptive changes in morphology of Daphnia filter appendages in response to food stress. Pol J Ecol 54:663-668

Beninger PG (2000) A critique of premises and methods in a recent study of particle capture mechanisms in bivalves. Limnol Oceanogr 45:1196-1199

Beninger PG, Le Pennec M, Salaün M (1988) New observations of the gills of Placopecten magellanicus (Mollusca: Bivalvia), and implications for nutrition. Mar Biol 98:61-70

Beninger PG, Ward JE, MacDonald BA, Thompson RJ (1992) Gill function and particle transport in Placopecten magellanicus (Mollusca: Bivalvia) as revealed using video endoscopy. Mar Biol 114:281-288

Beninger PG, Decottignies P, Rincé Y (2004) Localization of qualitative particle selection sites in the heterohabdic filibranch Pecten maximus (Bivalvia: Pectinidae). Mar Ecol Prog Ser 275:163-173

Beninger PG, Cannuel R, Jaunet S (2005) Particle processing on the gill plicae of the oyster Crassostrea gigas: fine-scale mucocyte distribution and functional correlates. Mar Ecol Prog Ser 295:191-199

Bergquist PR (1978) Sponges. University of California, Berkeley, CA

Bidder GP (1923) The relation of the form of a sponge to its currents. Q J Microsc Sci 67:293-323

Blake JR (1971) Infinite models for ciliary propulsion. J Fluid Mech 49:209-222

> Blake JR (1972) A model for the micro-structure in ciliated organisms. J Fluid Mech 55:1-23

Bone Q, Braconnot JC, Carré C, Ryan KP (1991) On the pharyngeal feeding filter of the salp Pegea confoederata (Tunicata: Thaliacea). Acta Zool 72:55-60

Bone Q, Braconnot JC, Carré C, Ryan KP (1997) On the filterfeeding of Doliolum (Tunicata: Thaliacea). J Exp Mar Biol Ecol 179:179-193

Boyd CM (1976) Selection of particle sizes by filter-feeding copepods: a plea for reason. Limnol Oceanogr 21:175-180

Brendelberger H (1985) Filter mesh-size and retention efficiency for small particles: comparative studies with Cladocera. Arch Hydrobiol Beih 21:135-146

Brendelberger H (1991) Filter mesh size of cladocerans predicts retention efficiency for bacteria. Limnol Oceanogr 36:884-894

> Brendelberger H, Geller W (1985) Variability of filter structures in eight Daphina species: mesh sizes and filtering areas. J Plankton Res 7:473-486

Brendelberger H, Herbeck M, Lang H (1986) Daphnia's filters are not solid walls. Arch Hydrobiol 107:197-202

Brown SC (1977) Biomechanics of water-pumping by Chaetopterus variopedatus Renier: kinetics and hydrodynamics. Biol Bull Mar Biol Lab Woods Hole 153:121-132

Buchanan JB (1964) A comparative study of some features of biology of Amphiura filiformis and Amphiura chiajei (Ophiuroidea) considered in relation to their distribution.
J Mar Biol Assoc UK 44:565-576

$>$ Buhr KJ (1976) Suspension-feeding and assimilation efficiency in Lanice conchilega (Polychaeta). Mar Biol 38: 373-383

Buhr KJ, Winter JE (1977) Distribution and maintenance of a Lanice conchilega association in the Weser estuary (FRG), with special reference to the suspension-feeding behaviour of Lanice conchilega. In: Keegan BF, Ceidigh PO, Boaden PJS (eds) Biology of benthic organisms. Pergamon Press, New York, NY, p 101-113

Cannon HG (1928) On the feeding mechanism of the fairy shrimp, Chirocephalus diaphanus Prévost. Trans R Soc Edinb 55:807-822

Cannon HG (1929) On the feeding mechanism of the copepods, Calanus finmarchicus and Diaptomus gracilis. Brit J Exp Biol 6:131-144

Cannon HG (1933) On the feeding mechanisms of the Branchiopoda. Philos Trans R Soc B 222:267-352

Cannuel R, Beninger PG (2007) Acquisition of particle processing capability in juvenile oyster Crassostrea gigas: ontogeny of gill mucocytes. Mar Biol 151:897-905

Cannuel R, Beninger PG, McCombe H, Boudry P (2009) Gill development and its functional and evolutionary implications in the blue mussel Mytilus edulis (Bivalvia: Mytilidae). Biol Bull 217:173-188

Chan BKK, Garm A, Høeg JT (2008) Setal morphology and cirral setation of thoracian barnacle cirri: adaptations and implications for thoracian evolution. J Zool 275:294-306

Cheer AYL, Koehl MAR (1987) Paddles and rakes: fluid flow through bristled appendages of small organisms. J Theor Biol 129:17-39

Coelho VR, Cooper RA, Rodrigues SA (2000) Burrow morphology and behavior of the mud shrimp Upogebia omissa (Decapoda: Thalassinidea: Upogebiidae). Mar Ecol Prog Ser 200:229-240

> Colin SP, Costello JH, Graham WH, Higgins J (2005) Omnivory by small cosmopolitan hydromedusa Aglaura hemistoma. Limnol Oceanogr 50:1264-1268

Costello JH, Colin SP (1994) Morphology, fluid motion and predation by the scyphomedusa Aurelia aurita. Mar Biol 121:327-334

Costello JH, Colin SP (1995) Flow and feeding by swimming scyphomedusae. Mar Biol 124:399-406

Costello JH, Loftus R, Waggett R (1999) Influence of prey detection on capture success for the ctenophore Mnemiopsis leidyi feeding upon adult Acartia tonsa and Oithona colcarva copepods. Mar Ecol Prog Ser 191:207-216

Crisp DJ, Southward AJ (1961) Different types of cirral activity of barnacles. Philos Trans R Soc B 243:271-307

Daborn GR (1979) Limb structure and sexual dimorphism in the Anostraca (Crustacea). Can J Zool 57:894-900

> Deibel D (1986) Feeding mechanism and house of the appendicularian Oikopleura vanhoeffeni. Mar Biol 93:429-436

Deibel D, Paffenhöfer GA (1988) Cinematographic analysis of the feeding mechanism of the pelagic tunicate Doliolum nationalis. Bull Mar Sci 43:404-412

> Deibel D, Powell CVL (1987) Ultrastructure of the pharyngeal filter of the appendicularian Oikopleura vanhoeffeni: implications for particle size selection and fluid mechanics. Mar Ecol Prog Ser 35:243-250

> Deibel D, Dickson ML, Powell CVL (1985) Ultrastructure of the mucous feeding filter of the house of the appendicularian Oikopleura vanhoeffeni. Mar Ecol Prog Ser 27:79-86

$>$ Dral ADG (1967) The movement of the latero-frontal cilia and the mechanism of particle retention in the mussel (Mytilus edulis L.). Neth J Sea Res 3:391-422

Dubois S, Barillé L, Cognie B, Beninger PG (2005) Particle 
capture and processing mechanisms in Sabellaria alveolata (Polychaeta: Sabellariidae). Mar Ecol Prog Ser 301: 159-171

$>$ Dworschak PC (1981) The pumping rates of the burrowing shrimp Upogebia pusilla (Petagna) (Decapoda: Thalassinidea). J Exp Mar Biol Ecol 52:25-35

Dworschak PC (1987) Feeding behaviour of Upogebia pusilla and Callianassa tyrrhena (Crustacea, Decapoda, Thalassinidea). Investig Pesq 51:421-429

Emlet R (1990) Flow fields around ciliated larvae: effects of natural and artificial tethers. Mar Ecol Prog Ser 63: 211-225

Espinosa EP, Perrigault M, Ward JE, Shumway SE, Allam B (2009) Implication of lectins associated with feeding organs in particle selection in the oyster Crassostrea virginica. Biol Bull 217:130-141

Evans SM (1971) Behavior in polychaetes. Q Rev Biol 46: 379-405

Fauchald K, Jumars P (1979) The diet of worms: a study of polychaete feeding guilds. Oceanogr Mar Biol Annu Rev 17:193-284

Fenchel T (1982) Ecology of heterotrophic microflagellates. I. Some important forms and their functional morphology. Mar Ecol Prog Ser 8:211-223

Fenchel T (2008) The microbial loop - 25 years later. J Exp Mar Biol Ecol 366:99-103

Fiala-Médioni A (1978) A scanning electron microscope study of the branchial sac of benthic filter-feeding invertebrates (Ascidians). Acta Zool 59:1-9

Fisher WK, MacGinitie GE (1928) A new echiuroid worm from California. Ann Mag Nat Hist 1:199-204

Fjerdingstad EJ (1961a) The ultrastructure of choanocyte collars in Spongilla lacustris (L.). Z Zellforsch 53:645-657

Fjerdingstad EJ (1961b) Ultrastructure of the collar of the choanoflagellate Codonosiga botrytis (Ehrenb.). Z Zellforsch 54:499-510

Flood PR (1981) On the ultrastructure of mucus. Biomed Res 2(Suppl):49-53

- Flood PR (1991) Architecture of, and water circulation and flow rate in, the house of the planktonic tunicate Oikopleura labradorienses. Mar Biol 111:95-111

Flood PR (2003) House formation and feeding behaviour of Fritillaria borealis (Appendicularia: Tunicata). Mar Biol 143:467-475

Flood PR, Fiala-Médioni A (1981) Ultrastructure and histochemistry of the branchial sac of benthic filter-feeding invertebrates (Ascidians). Acta Zool 59:1-9

> Flood PR, Fiala-Médioni A (1982) Structure of the mucous feeding filter of Chaetopterus variopedatus (Polychaeta). Mar Biol 72:27-33

Ford MD, Costello JH, Heidelberg KB (1997) Swimming and feeding by the scyphomedusa Chrysaora quinquecirrha. Mar Biol 129:355-362

Franc JM (1978) Organization and function of ctenophore colloblasts: an ultrastructural study. Biol Bull 155:527-541

Fraser EH (1969) A study of the biological activity of toxic material derived from nematocysts of the cubomedusan Chironex fleckeri. Toxicon 6:179-204

Frost TM (1978) In situ measurements of clearance rates for the freshwater sponge Spongilla lacustris. Limnol Oceanogr 23: 1034-1039

Fryer G (1983) Functional ontogenetic changes in Branchinecta ferox (Milne-Edwards) (Crustacea: Anostraca). Philos Trans R Soc Lond B 303:229-343

Fryer G (1987) The feeding mechanisms of Daphniidae (Crustacea: Cladocera): recent suggestions and neglected considerations. J Plankton Res 9:419-432
Gallager SM (1988) Visual observations of particle manipulation during feeding in larvae of a bivalve mollusc. Bull Mar Sci 43:344-365

Ganf GG, Shiel RJ (1985) Particle capture by Daphina carinata. Aust J Mar Freshw Res 36:371-381

> Geierman C, Emlet R (2009) Feeding behavior, cirral fan anatomy, Reynolds number, and leakiness of Balanus glandula, from post-metamorphic juvenile to the adult. J Exp Mar Biol Ecol 379:68-76

Gerlach SA, Ekstrøm DK, Eckardt PB (1976) Filter feeding in the hermit crab. Oecologia 24:257-264

Gerritsen J, Porter KG (1982) The role of surface chemistry in filter feeding by zooplankton. Science 216:1225-1227

Gerritsen J, Porter KG, Strickler JR (1988) Not by sieving alone: observations of suspension feeding in Daphina. Bull Mar Sci 43:366-376

Gilmer RW (1972) Free-floating mucus webs: a novel feeding adaptation for the open ocean. Science 176:1239-1240

Gilmer RW (1990) In situ observations of feeding in thecosomatous pteropod molluscs. Am Malacol Bull 8:53-59

Gilmer RW, Harbison GR (1986) Morphology and field behaviour of pteropod molluscs: feeding methods in the families Cavoliniidae, Limacinidae and Peraclididae (Gastropoda: Thecosomata). Mar Biol 91:47-57

Gilmer RW, Harbison GR (1991) Diet of Lamacina helicina (Gastropoda: Thecosomata) in Arctic waters in midsummer. Mar Ecol Prog Ser 77:125-134

Gilmour THJ (1978) Ciliation and function of the food-collecting and waste-rejecting organs of lophophorates. Can J Zool 56:2142-2155

Gilmour THJ (1981) Food-collecting and waste-rejecting mechanisms in Glottidia pyramidata and the persistence of lingulacean inarticulate brachiopods in the fossil record. Can J Zool 59:1539-1547

Gilmour THJ (1985) An analysis of videotape recordings of larval feeding in the sea urchin Lytechinus pictus (Verrill). Can J Zool 63:1354-1359

Gilmour THJ (1986) Streamlines and particle paths in the feeding mechanisms of larvae of the sea urchin Lytechinus pictus Verril. J Exp Mar Biol Ecol 95:27-36

Gilmour THJ (1988) Feeding behaviour of holothurian larvae. Am Zool 28:167A (Abstract)

Goerke H (1966) Nahrungsfiltration von Nereis diversicolor O. F. Müller (Nereidae, Polychaeta). Veroeff Inst Meeresforsch Bremerhav 10:49-58

Gophen M, Geller W (1984) Filter mesh size and food particle uptake by Daphnia. Oecologia 66:368-372

Gordon DP (1974) Microarchitecture and function of the lophophore in the bryozoan Cryptosula pallasiana. Mar Biol 27:147-163

Gordon DP, Clark AG, Harper JF (1987) Bryozoa. In: Animal energetics, Vol 2. Academic Press, London, p 173-199

Green S, Visser AW, Titelman J, Kiørboe T (2003) Escape responses of copepod nauplii in the flow field of the blue mussel, Mytilus edulis. Mar Biol 142:727-733

Grünbaum D (1995) A model of feeding currents in encrusting bryozoans shows interference between zooids within a colony. J Theor Biol 174:409-425

Grünbaum D, Eyre D, Fogelson A (1998) Functional geometry of ciliated tentacular arrays in active suspension feeders. J Exp Biol 201:2575-2589

Gueron S, Levit-Gurevich K (1998) Computation of the internal forces in cilia: application to ciliary motion, the effects of viscosity, and cilia interactions. Biophys J 74:1658-1676

Gueron S, Liron N (1992) Ciliary motion modeling, and dynamic multicilia interactions. Biophys J 63:1045-1058

Hall VE (1931) The muscular activity and oxygen consump- 
tion of Urechis caupo. Biol Bull 61:400-416

Hamner WM (1988) Biomechanics of filter feeding in the Antarctic krill Euphausia superba: review of past work and new observations. J Crustac Biol 8:149-163

Hamner WM, Strand SW, Matsumoto GI, Hamner PP (1987) Ethological observations on foraging behavior of the ctenophore Leucothea sp. in the open sea. Limnol Oceanogr 32: 645-652

Hamner WM, Hamner PP, Obst BS (1989) Field observations on the ontogeny of schooling of Euphausia superba furciliae and its relationship to ice in Antarctic waters. Limnol Oceanogr 34:451-456

Hansen B (1991) Feeding behaviour in larvae of the opisthobranch Philine aperta. II. Food size spectra and particle selectivity in relation to larval behaviour and morphology of the velar structures. Mar Biol 111:263-270

Hansen B (1993) Aspects of feeding, growth and stage development by trochophora larvae of the boreal polychaete Mediomastus fragile (Rasmussen) (Capitellidae). J Exp Mar Biol Ecol 166:273-288

Hansen B, Tiselius P (1992) Flow through the feeding structures of suspension feeding zooplankton: a physical model approach. J Plankton Res 14:821-834

Hansson LJ (2006) A method for in situ estimation of prey selectivity and predation rate in large plankton, exemplified with the jellyfish Aurelia aurita (L.). J Exp Mar Biol Ecol 328:113-126

> Hansson LJ, Kiørboe T (2006) Prey-specific encounter rates and handling efficiencies of prey selectivity in ambushfeeding hydromedusae. Limnol Oceanogr 51:1849-1858

Happel J, Brenner J (1965) Low Reynolds number hydrodynamics. Prentice-Hall, Englewood Cliffs, NJ

Harbison GR, Madin LP, Swanberg NR (1978) On the natural history and distribution of oceanic ctenophores. Deep-Sea Res 25:233-256

> Harley MM (1950) Occurrence of a filter-feeding mechanism in the polychaete Nereis diversicolor. Nature 165:734-735

Hart MW (1991) Particle captures and the method of suspension feeding by echinoderm larvae. Biol Bull 180:12-27

Heeger T, Möller H (1987) Ultrastructural observations on prey capture and digestion in the scyphomedusa Aurelia aurita. Mar Biol 96:391-400

Hibberd DJ (1975) Observations on the ultrastructure of the choanoflagellate Codosiga botrytis (Ehr.) Saville-Kent with special reference to the flagellar apparatus. J Cell Sci 17:191-219

Holland ND, Strickler JR, Leonard AB (1986) Particle interception, transport and rejection by the feather star Oligometra serripinna (Echinodermata: Crinoidea), studied by frame analysis of videotapes. Mar Biol 93:111-126

Holley MC (1986) Cell shape, spatial patterns of cilia, and mucus-net construction in the ascidian endostyle. Tissue Cell 18:667-684

Humphries S (2007). Body size and suspension feeding. In: Hildrew AG, Raffaelli DG, Edmonds-Brown R (eds) Body size and the structure and function of aquatic ecosystems. Cambridge University Press, Cambridge, p 16-32

Humphries S (2009) Filter feeders and plankton increase particle encounter rates through flow regime control. Proc Natl Acad Sci USA 106:7882-7887

Hunt BPV, Pakhomov EA, Hosie GW, Siegel V, Ward P, Bernard K (2008) Pteropods in Southern Ocean ecosystems. Prog Oceanogr 78:193-221

Hyman LH (1940) The invertebrates, Vol 1. Protozoa through Ctenophora. McGraw-Hill, New York, NY

Jackson GA (1993) Flux feeding as a mechanism for zooplankton grazing and its implications for vertical particu- late flux. Limnol Oceanogr 38:1328-1331

Jiang H, Meneveau C, Osborn TR (2002) The flow field around a freely swimming copepod in steady motion. Part II: Numerical simulation. J Plankton Res 24:199-213

Jonsson PR, Tiselius P (1990) Feeding behaviour, prey detection and capture efficiency of the copepod Acartia tonsa feeding on planktonic ciliates. Mar Ecol Prog Ser 60:35-44

Jørgensen CB (1955) Quantitative aspects of filter feeding in invertebrates. Biol Rev Camb Philos Soc 30:391-454

Jørgensen CB (1966) Biology of suspension feeding. Pergamon Press, Oxford

- Jørgensen CB (1975a) Comparative physiology of suspension feeding. Annu Rev Physiol 37:57-79

Jørgensen CB (1975b) On gill function in the mussel Mytilus edulis L. Ophelia 13:187-232

> Jørgensen CB (1983) Fluid mechanical aspects of suspension feeding. Mar Ecol Prog Ser 11:89-103

Jørgensen CB (1990) Bivalve filter feeding: hydrodynamics, bioenergetics, physiology and ecology. Olsen \& Olsen, Fredensborg

Jørgensen CB (1996) Bivalve filter feeding revisited. Mar Ecol Prog Ser 142:287-302

> Jørgensen CB, Kiørboe T, Møhlenberg F, Riisgård HU (1984) Ciliary and mucus-net filter feeding, with special reference to fluid mechanical characteristics. Mar Ecol Prog Ser 15:283-292

> Jørgensen CB, Møhlenberg F, Sten-Knudsen O (1986) Nature of relation between ventilation and oxygen consumption in filter feeders. Mar Ecol Prog Ser 29:73-88

- Julian D, Chang ML, Judd JR, Arp AJ (2001) Influence of environmental factors on burrow irrigation and oxygen consumption in the mudflat invertebrate Urechis caupo. Mar Biol 139:163-173

Jumars PA (1993) Concepts in biological oceanography. An interdisciplinary primer. Oxford University Press, Oxford, p 348

Kils U (1983) Swimming and feeding of Antarctic krill, Euphausia superba-some outstanding energetics and dynamics - some unique morphological details. Ber Polarforsch 4:130-155

Kiørboe T (1997) Small-scale turbulence, marine snow formation, and planktivorous feeding. Sci Mar 61(Suppl 1): $141-158$

Kiørboe T (2008) A mechanistic approach to plankton ecology. Princeton University Press, Princeton, NJ

- Kiørboe T, Møhlenberg F (1981) Particle selection in suspension-feeding bivalves. Mar Ecol Prog Ser 5:291-296

> Kiørboe T, Saiz E (1995) Planktivorous feeding in calm and turbulent environments, with emphasis on copepods. Mar Ecol Prog Ser 122:135-145

Kiørboe T, Saiz E, Viitasalo M (1996) Prey switching behaviour in the planktonic copepod Acartia tonsa. Mar Ecol Prog Ser 143:65-75

Kiørboe T, Andersen AP, Langlois V, Jakobsen HH, Bohr T (2009) Mechanisms and feasibility of prey capture in ambush-feeding zooplankton. Proc Natl Acad Sci USA 106:12394-12399

Koehl MAR (1995) Fluid flow through hair-bearing appendages: feeding, smelling, and swimming at low and intermediate Reynolds number. In: Ellington $\mathrm{CP}$, Pedley TJ (eds) Biological fluid dynamics. Soc Exp Biol Symp 49: 157-182

> Koehl MAR, Strickler JR (1981) Copepod feeding currents: food capture at low Reynolds number. Limnol Oceanogr 26:1062-1073

> Kropp RK (1981) Additional porcelain crab feeding methods (Decapoda, Porcellanidae). Crustaceana 40:307-310 
Kropp RK (1986) Feeding biology and mouth part morphology of three species of coral gall crabs (Decapoda: Cryptochiridae). J Crustac Biol 6:377-384

LaBarbera M (1978) Particle capture by a pacific brittle star: experimental test of the aerosol suspension feeding model. Science 201:1147-1149

LaBarbera M (1984) Feeding currents and particle capture mechanisms in suspension feeding animals. Am Zool 24: $71-84$

Lalli CM, Gilmer RW (1989) Pelagic snails: the biology of holoplanktonic gastropod mollusks. Stanford University Press, Palo Alto, CA, p 259

Lampert W, Brendelberger H (1996) Strategies of phenotypic low-food adaptation in Daphnia: filter screens, mesh sizes, and appendage beat rates. Limnol Oceanogr 41:216-223

Larsen PS, Riisgård HU (1994) The sponge pump. J Theor Biol 168:53-63

Larsen PS, Riisgård HU (2002) On ciliary sieving and pumping in bryozoans. J Sea Res 48:181-195

> Lasker HR (1981) A comparison of the particulate feeding abilities of three species of gorgonian soft coral. Mar Ecol Prog Ser 5:61-67

Lauga E, Powers TR (2009) The hydrodynamics of swimming microorganisms. Rep Prog Phys 72:096601, doi:10.1088/ 0034-4885/72/9/096601

Laval M (1971) Ultrastructure et mode de nutrition du choanoflagellé Salpingoeca pelagica, sp. nov. Comparaison avec les choanocytes des spongiaires. Protistologica 7 : 325-336

> Lawry JV (1966) Neuromuscular mechanisms of burrow irrigation in the echiuroid worm Urechis caupo (Fisher and MacGinitie). I: Anatomy of the neuromuscular system and activity of intact animals. J Exp Biol 45:343-356

Leonard AB, Strickler JR, Holland ND (1988) Effects of current speed on filtration during suspension feeding on Oligometra serripinna (Echinodermata: Crinoidea). Mar Biol 97:111-125

Lewis JB, Price WS (1975) Feeding mechanisms and feeding strategies of Atlantic reef corals. J Zool Lond 176:527-544

Leys SP, Eerkes-Medrano DI (2006) Feeding in a calcareous sponge: particle uptake by pseudopodia. Biol Bull 211: $157-171$

Loo LO, Baden SP, Ulmestrand M (1993) Suspension feeding in adult Nephrops norvegicus (L.) and Homarus gammarus (L.) (Decapoda). Neth J Sea Res 31:291-297

Loo LO, Jonsson PR, Sköld M, Karlsson Ö (1996) Passive suspension feeding in Amphiura filiformis (Echinodermata: Ophiuroidea): feeding behaviour in flume flow and potential feeding rate of field populations. Mar Ecol Prog Ser 139:143-155

Lutaud G (1973) L'innervation du lophophore chez le Bryozoaire chilostome Electra pilosa (L.). Z Zellforsch Mikrosk Anat 140:217-234

MacGinitie GE (1939) The method of feeding of Chaetopterus. Biol Bull Mar Biol Lab (Woods Hole) 77:115-118

MacGinitie GE (1945) The size of mesh openings in mucus feeding nets of marine animals. Biol Bull 88:107-111

Machácek J (1998) What can we learn from Daphnia filtering screens? J Plankton Res 30:1645-1650

Main RJ (1928) Observations of the feeding mechanism of a ctenophore, Mnemiopsis leidyi. Biol Bull 55:69-78

> Manjulatha C, Babu DE (1991) Functional organisation of mouth parts, and filter feeding, in Clibanarius longitarsus (Crustacea: Anomura). Mar Biol 109:121-127

Marchinko KB (2007) Feeding behavior reveals the adaptive nature of plasticity in barnacle feeding limbs. Biol Bull 213:12-15
Marchinko KB, Palmer AR (2003) Feeding in flow extremes: dependence of cirrus form on wave-exposure in four barnacle species. Zoology 106:127-141

Marr JWS (1962) The natural history and geography of the Antarctic krill (Euphausia superba). Discov Rep 32:33-464

Marshall SM, Orr AP (1966) Respiration and feeding in some small copepods. J Mar Biol Assoc UK 46:513-530

Matsumoto GI, Hamner WM (1988) Modes of water manipulation by the lobate ctenophore Leucothea sp. Mar Biol 97: 551-558

Matsumoto GI, Harbison GR (1993) In situ observations of foraging, feeding and escape behavior in three orders of oceanic ctenophores: Lobata, Cestida and Beroida. Mar Biol 117:279-287

Mattson S, Cedhagen T (1989) Aspects of the behaviour and ecology of Dyopedos monacanthus (Metz ger) and D. porrectus Bate, with comparative notes on Dulichia tuberculata Boeck (Crustacea: Amphipoda: Podoceridae). J Exp Mar Biol Ecol 127:253-272

- Mayer S (1994) Particle capture in the crown of the ciliary suspension feeding polychaete Sabella penicillus: video recordings and interpretations. Mar Biol 119:571-582

Mayer S (2000) Numerical simulation of flow fields and particle trajectories in ciliary suspension feeding. Bull Math Biol 62:1035-1059

McHenery JG, Birkbeck TK (1985) Uptake and processing of cultured microorganisms by bivalves. J Exp Mar Biol Ecol 90:145-163

McNeill Alexander R (1975) The chordates. Cambridge University Press, Cambridge

McWhinnie MA, Denys CJ (1980) The high importance of lowly krill. Nat Hist 89:66-73

Mertens J, Munuswamy N, Walsche CD, Dumont HJ (1991) The filtration apparatus of Anostraca (Crustacea): speciesspecific setulation in the genus Streptocephalus. Hydrobiologia 212:187-193

Millar RH (1971) The biology of ascidians. Adv Mar Biol 9: $1-100$

Miller DC (1984) Mechanical post-capture particle selection by suspension- and deposit-feeding Corophium. J Exp Mar Biol Ecol 82:59-76

Miller DC, Bock MJ, Turner EJ (1992) Deposit and suspension feeding in oscillatory flows and sediment fluxes. J Mar Res 50:489-520

Møhlenberg F, Riisgård HU (1978) Efficiency of particle retention in 13 species of suspension-feeding bivalves. Ophelia 17:239-246

> Møller LF, Riisgård HU (2006) Filter feeding in the burrowing amphipod Corophium volutator. Mar Ecol Prog Ser 322: 213-224

Moore HJ (1971) The structure of the latero-frontal cirri on the gills of certain lamellibranch molluscs and their role in suspension feeding. Mar Biol 11:23-27

Morris CC, Deibel D (1993) Flow rate and particle concentration within the house of the pelagic tunicate Oikopleura vanhoeffeni. Mar Biol 115:445-452

> Morton JE (1954) The biology of Limacina retroversa. J Mar Biol Assoc UK 33:297-312

Mukai H, Terakado K, Reed CG (1997) Bryozoa. In: Harrison FW (ed) Microscopic anatomy of invertebrates, Vol 13. Wiley-Liss, New York, NY, p 45-206

Nagabhushanam AK (1959) Feeding of a ctenophore, Bolinopsis infundibulum (O.F. Muller). Nature 184:829

> Navarro JM, Chaparro OR (2002) Grazing-filtration as feeding mechanisms in motile specimens of Crepidula fecunda (Gastropoda: Calyptraeidae). J Exp Mar Biol Ecol 270:111-122 Nelson TC (1960) The feeding mechanism of the oyster. II. On 
the gills and palps of Ostrea edulis, Crassostrea virginica and C. angulata. J Morphol 107:163-203

Nickell LA, Atkinson RJA (1995) Functional morphology of burrows and trophic modes of three thalassinidean shrimp species, and a new approach to the classification of thalassinidean burrow morphology. Mar Ecol Prog Ser 128:181-197

> Nicol EAT (1932) The feeding habits of the Galatheidea. J Mar Biol Assoc UK 18:87-106

$>$ Nielsen C (1987) Structure and function of metazoan ciliary bands and their phylogenetic significance. Acta Zool 68: 205-262

Nielsen C (2001) Animal evolution: interrelationships of the living phyla, 2nd edn. Oxford University Press, Oxford

> Nielsen C (2002) Ciliary filter-feeding structures in adult and larval gymnolaemate bryozoans. Invertebr Biol 121: 255-261

Nielsen C, Riisgård HU (1998) Tentacle structure and filterfeeding in Crisia eburnea and other cyclostomatous bryozoans, with a review of upstream-collecting mechanisms. Mar Ecol Prog Ser 168:163-186

Nielsen C, Rostgaard J (1976) Structure and function of an entoproct tentacle with discussion of ciliary feeding types. Ophelia 15:115-140

- Nielsen NF, Larsen PS, Riisgård HU, Jørgensen CB (1993) Fluid motion and particle retention in the gill of Mytilus edulis: video recordings and numerical modelling. Mar Biol 116:61-71

Nielsen SE, Bone Q, Bond P, Harper G (2007) On particle filtration by amphioxus (Branchiostoma lanceolatum). J Mar Biol Assoc UK 87:983-989

Nival P, Nival S (1976) Particle retention efficiencies of a herbivorous copepod Acartia clausi (adult and copepodite stages): effects on grazing. Limnol Oceanogr 21:24-38

> Nival P, Nival S (1979) Calculations of particle retention efficiency. Limnol Oceanogr 24:995-998

Olesen NJ, Frandsen K, Riisgård HU (1994) Population dynamics, growth and energetics of jellyfish Aurelia aurita in a shallow fjord. Mar Ecol Prog Ser 105:9-18

> Olsson R (1963) Endostyles and endostylar secretions: a comparative histochemical study. Acta Zool 44:299-328

> Orton JH (1913) The ciliary mechanisms on the gill and the mode of feeding in amphioxus, ascidians and Solenomya togata. J Mar Biol Assoc UK 10:19-49

Orton JH (1915) On ciliary mechanisms in branchiopods and some polychaetes, with a comparison of the ciliary mechanisms on the gills of molluscs, protochordata, branchiopods, and cryptocephalus polychaetes, and an account of the endostyle of Crepidula and its allies. J Mar Biol Assoc UK 10:283-311

Osovitz CJ, Julian D (2002) Burrow irrigation behavior of Urechis caupo, a filter-feeding marine invertebrate, in its natural habitat. Mar Ecol Prog Ser 245:149-155

> Owen G (1974) Studies on the gill of Mytilus edulis: the eulatero-frontal cirri. Proc R Soc Lond B Biol Sci 187:83-91

- Owen G, McCrae JM (1976) Further studies on the laterofrontal tract of bivalves. Proc R Soc Lond B Biol Sci 194: 527-544

Paffenhöfer GA, Strickler JR, Alcaraz M (1982) Suspensionfeeding by herbivorous calanoid copepods: a cinematographic study. Mar Biol 67:193-199

Palmer M, Nepf H, Petterson T, Ackerman J (2004) Observations of particle capture on a cylindrical collector: implications for particle accumulation and removal in aquatic systems. Limnol Oceanogr 49:76-84

Patterson MR (1984) Patterns of whole colony prey capture in the octocoral, Alcyonium siderium. Biol Bull 167:613-629 Price HJ, Paffenhöfer GA (1986) Capture of small cells by the copepod Eucalanus elongatus. Limnol Oceanogr 31:189-194 Pritchard A, White FN (1980) Metabolism and oxygen transport in the innkeeper worm Urechis caupo. Physiol Zool $54: 44-54$

Purcell JE (1997) Pelagic cnidarians and ctenophores as predators: selective predation, feeding rates, and effects on prey populations. Ann Inst Oceanogr 73:125-137

Purcell JE, Mills CE (1988). The correlation of nematocyst types to diets in pelagic Hydrozoa. In: Hessinger DA, Lenhoff HM (eds) The biology of nematocysts. Academic Press, San Diego, CA, p 463-495

Rähr H (1982) Ultrastructure of gill bars of Branchiostoma lanceolatum with special reference to gill skeleton and blood vessels (Cephalochordata). Zoomorphology 99:167-180

Randløv A, Riisgård HU (1979) Efficiency of particle retention and filtration rate in four species of ascidians. Mar Ecol Prog Ser 1:55-59

> Rapoza R, Novak D, Costello JH (2005) Life-stage dependent, in situ dietary patterns of the lobate ctenophore Mnemiopsis leidyi Agassiz 1885. J Plankton Res 27:951-956

Reeve MR, Walter MA (1978) Nutritional ecology of ctenophores — a review of recent research. Adv Mar Biol 15:249-287

- Reiswig HM (1971) Particle feeding in natural populations of three marine demosponges. Biol Bull 141:568-591

> Reiswig HM (1975) The aquiferous systems of three marine demospongiae. J Morphol 145:493-502

> Riisgård HU (1988) Efficiency of particle retention and filtration rate in 6 species of Northeast American bivalves. Mar Ecol Prog Ser 45:217-223

> Riisgård HU (1989) Properties and energy cost of the muscular piston pump in the suspension feeding polychaete Chaetopterus variopedatus. Mar Ecol Prog Ser 56:157-168

- Riisgård HU (1991) Suspension feeding in the polychaete Nereis diversicolor. Mar Ecol Prog Ser 70:29-37

Riisgård HU (1994) Filter-feeding in the polychaete Nereis diversicolor: a review. Neth J Aquat Ecol 28:453-458

Riisgård HU (2002) The methods of ciliary filter feeding in the adult Phoronis muelleri and its free swimming actinotrocha larva. Mar Biol 141:75-87

Riisgård HU (2007a) Biomechanics and energy cost of the amphipod Corophium volutator filter-pump. Biol Bull 212: 104-114

Riisgård HU (2007b) Feeding behaviour of the hydromedusa Aequorea vitrina. Sci Mar 71:395-404

> Riisgård HU, Ivarsson NM (1990) The crown-filament pump of the suspension-feeding polychaete Sabella penicillus: filtration, effects of temperature and energy cost. Mar Ecol Prog Ser 62:249-257

Riisgård HU, Kamermans P (2001) Switching between deposit and suspension feeding in coastal zoobenthos. In: Reise K (ed) Ecological comparisons of sedimentary shores. Ecological studies. Springer-Verlag, Berlin, p 73-101

> Riisgård HU, Larsen PS (1995) Filter-feeding in marine macroinvertebrates: pump characteristics, modelling and energy cost. Biol Rev Camb Philos Soc 70:67-106

Riisgård HU, Larsen PS (2000) A comment on experimental techniques for studying particle capture in filter-feeding bivalves. Limnol Oceanogr 45:1192-1195

Riisgård HU, Larsen PS (2001) Ciliary filter feeding and biofluid mechanics - present understanding and unsolved problems. Limnol Oceanogr 46:882-891

Riisgård HU, Larsen PS (2005) Water flow analysis and particle capture in ciliary suspension-feeding scallops (Pectinidae). Mar Ecol Prog Ser 303:177-193

Riisgård HU, Manríquez P (1997) Filter-feeding in fifteen marine ectoprocts (Bryozoa): particle capture and water pumping. Mar Ecol Prog Ser 154:223-239 
Riisgård HU, Nielsen C (2006) Feeding mechanism of the polychaete Sabellaria alveolata: comment on Dubois et al. (2005). Mar Ecol Prog Ser 328:295-305

Riisgård HU, Schotge P (2007) Surface deposit-feeding versus filter-feeding in the amphipod Corophium volutator. Mar Biol Res 3:421-427

$>$ Riisgård HU, Svane I (1999) Filter feeding in lancelets (amphioxus) Brachiostoma lanceolatum. Invertebr Biol 118:423-432

Riisgård HU, Vedel A, Boye H, Larsen PS (1992) Filter-net structure and pumping activity in the polychaete Nereis diversicolor: effects of temperature and pump-modelling. Mar Ecol Prog Ser 83:79-89

Riisgård HU, Thomassen S, Jakobsen H, Weeks JM, Larsen PS (1993) Suspension feeding in marine sponges Halichondria panicea and Haliclona urceolus: effects of temperature on filtration rate and energy cost of pumping. Mar Ecol Prog Ser 96:177-188

Riisgård HU, Larsen PS, Nielsen NF (1996) Particle capture in the mussel Mytilus edulis: the role of latero-frontal cirri. Mar Biol 127:259-266

Riisgård HU, Nielsen C, Larsen PS (2000) Downstream collecting in ciliary suspension feeders: the catch-up principle. Mar Ecol Prog Ser 207:33-51

Riisgård HU, Nielsen KK, Fuchs J, Rasmussen BF, Obst M, Funch P (2004) Ciliary feeding structures and particle capture mechanism in the freshwater bryozoan Plumatella repens. Invertebr Biol 123:155-166

Riisgård HU, Okamura B, Funch P (2009) Particle capture in ciliary filter feeding gymnolaemate and phylactolaemate bryozoans - a comparative study. Acta Zool 91:416-425 doi:10.1111/j.1463-6395.2009.00417.x

Romero MR, Kelstrup HCP, Strathmann RR (2010) Capture of particles by direct interception by cilia during feeding of a gastropod veliger. Biol Bull 218:145-159

Rosenberg GG (1980) Filmed observations of filter feeding in the marine planktonic copepod Acartia clausii. Limnol Oceanogr 25:738-742

Ross RM, Quetin LB (1983) Spawning frequency and fecundity of the Antarctic krill Euphausia superba. Mar Biol 77: 201-205

Roushdy HM, Hansen VK (1961) Filtration of phytoplankton by the octocoral Alcyonium digitatum L. Nature 190: 649-650

Rubenstein D, Koehl MAR (1977) Mechanisms of filter feeding — some theoretical considerations. Am Nat 111:981-994

Ruppert EE, Nash TR, Smith AJ (2000) The size range of suspended particles trapped and ingested by the filter-feeding lancet Branchiostoma floridae (Cephalochorda: Acrania). J Mar Biol Assoc UK 80:329-332

Ryland JS (1976) Physiology and ecology of marine bryozoans. Adv Mar Biol 14:285-443

Saiz E, Kiørboe T (1995) Predatory and suspension feeding of the copepod Acartia tonsa in turbulent environments. Mar Ecol Prog Ser 122:147-158

Schulze-Robbecke AC (1984) Functional morphology of Bolinopsis infundibulum (ctenophore). Helgol Meersunters 38:47-64

Schuhmacher H (1977) A hermit crab, sessile on corals, exclusively feeds by feathered antemmae. Oecologia 27:371-374

Scott PJB, Reiswig HM, Marcotte BM (1988) Ecology, functional morphology, behaviour, and feeding in coral- and sponge-boring species of Upogebia (Crustacea: Decapoda: Thalassinidea). Can J Zool 66:483-495

Shimeta JS, Jumars PA (1991) Physical mechanisms and rates of particle capture by suspension feeders. Oceanogr Mar Biol Annu Rev 29:191-257
Shimeta J, Koehl MAR (1997) Mechanisms of particle selection by tentaculate suspension feeders during encounter, retention, and handling. J Exp Mar Biol Ecol 209:47-73

Shimeta J, Witucki PF, Hippe KR (2004) Influences of nutritional state and temperature on suspension-feeding rates and mechanics in the spionid polychaete Polydora cornuta. Mar Ecol Prog Ser 280:173-180

Silverman H, Achberger EC, Lynn JW, Dietz TH (1995) Filtration and utilization of laboratory-cultured bacteria by Dreissena polymorpha, Corbicula fluminea, and Carunculina texasensis. Biol Bull 189:308-319

Silverman H, Lynn JW, Dietz TH (1996) Particle capture by the gills of Dreissena polymorpha: structure and function of laterofrontal cirri. Biol Bull 191:42-54

Silverman H, Lynn JW, Beninger PG, Dietz TH (1999) The role of latero-frontal cirri in particle capture by the gills of Mytilus edulis. Biol Bull 197:368-376

Silverman H, Lynn JW, Dietz TH (2000) In vitro studies of particle capture and transport in suspension-feeding bivalves. Limnol Oceanogr 45:1199-1203

> Silvester NR (1983) Some hydrodynamic aspects of filter feeding with rectangular-mesh nets. J Theor Biol 103:265-286

> Silvester NR, Sleigh MA (1984) Hydrodynamic aspects of particle capture by Mytilus. J Mar Biol Assoc UK 64:859-897

Simpson TL (1984) The cell biology of sponges. SpringerVerlag, New York, NY

- Slattery M, McClintock JB, Bowser SS (1997) Deposit feeding: a novel model of nutrition in the Antarctic colonial soft coral Germesia antarctica. Mar Ecol Prog Ser 149:299-304

- Southward AJ (1955a) Feeding of barnacles. Nature 175: $1124-1125$

Southward AJ (1955b) Observations on the ciliary currents of the jelly-fish Aurelia aurita L. J Mar Biol Assoc UK 34: 201-216

Sponaugle S (1991) Flow patterns and velocities around a suspension-feeding gorgonian polyp: evidence from physical models. J Exp Mar Biol Ecol 148:135-145

> Sponaugle S, LaBarbera M (1991) Drag-induced deformation: a functional feeding strategy in two species of gorgonians. J Exp Mar Biol Ecol 148:121-134

> Stamhuis EJ, Videler JJ (1998a) Burrow ventilation in the tube-dwelling shrimp Callianassa subterranea (Decapoda: Thalassinidea). I. Morphology and motion of the pleopods, uropods and telson. J Exp Biol 201:2151-2158

Stamhuis EJ, Videler JJ (1998b) Burrow ventilation in the tube-dwelling shrimp Callianassa subterranea (Decapoda: Thalassinidea). II. The flow in the vicinity of the shrimp and the energetic advantages of a laminar non-pulsating ventilation current. J Exp Biol 201:2159-2170

> Stamhuis EJ, Videler JJ (1998c) Burrow ventilation in the tube-dwelling shrimp Callianassa subterranea (Decapoda: Thalassinidea). III. Hydrodynamic modelling and energetics of pleopod pumping. J Exp Biol 201:2171-2181

Stoecker D, Michaels AE, Davis LH (1987) Grazing by the jellyfish, Aurelia aurita, on microzooplankton. J Plankton Res 9:901-915

Strathmann R (1971) The feeding behaviour of planktotrophic echinoderm larvae: mechanisms, regulation, and rates of suspension feeding. J Exp Mar Biol Ecol 6:109-160

Strathmann RR (1973) Function of lateral cilia in suspension feeding of lophophorates (Brachiopoda, Phoronida, Ectoprocta). Mar Biol 23:129-136

Strathmann RR (1975) Larval feeding in echinoderms. Am Zool 15:717-730

Strathmann RR (1982) Cinefilms of particle capture by an induced local change of beat of lateral cilia of a bryozoan. J Exp Mar Biol Ecol 62:225-236 
Strathmann RR (1987) Larval feeding. In: Giese AC, Pearse JS, Pearse VB (eds) Reproduction of marine invertebrates. Vol. IX. General aspects: seeking unity in diversity. Blackwell Scientific Publications, Palo Alto, CA, p 465-550

Strathmann RR (2005) Ciliary sieving and active ciliary response in capture of particles by suspension-feeding brachiopod larvae. Acta Zool 86:41-54

Strathmann RR (2006) Versatile ciliary behaviour in capture of particles by the bryozoan cyphonautes larva. Acta Zool 87: 83-89

Strathmann RR (2007) Time and extent of ciliary response to particles in a non-filtering feeding mechanism. Biol Bull 212:93-103

> Strathmann RR, Bone Q (1997) Ciliary feeding assisted by suction from the muscular oral hood of phoronid larvae. Biol Bull 193:153-162

Strathmann RR, Leise E (1979) On feeding mechanisms and clearance rates of molluscan veligers. Biol Bull 157: 524-535

Strathmann RR, McEdward LR (1986) Cyphonautes' ciliary sieve breaks a biological rule of inference. Biol Bull 171: $694-700$

> Strathmann RR, Jahn TL, Fonesca JR (1972) Suspension feeding by marine invertebrate larvae: clearance of particles by ciliated bands of a rotifer, pluteus, and trochophore. Biol Bull 142:505-519

Suchman CL (2000) Escape behavior of Acartia hudsonica copepods during interactions with scyphomedusae. J Plankton Res 22:2307-2323

Suh HL, Choi SD (1998) Comparative morphology of the feeding basket of five species of Euphausia (Crustacea, Euphausiacea) in the western North Pacific, with some ecological considerations. Hydrobiologia 385:107-112

Suh HL, Nemoto T (1987) Comparative morphology of filtering structure of 5 species of Euphausia (Euphausiacea, Crustacea) from the Antarctic Ocean. Proc NIPR Symp Polar Biol 1:72-83

Sullivan LJ, Gifford DJ (2004) Diet of the larval ctenophore Mnemiopsis leidyi A. Agassiz (Ctenophora, Lobata). J Plankton Res 26:417-431

Sullivan BK, Garcia JR, Klein-MacPhee G (1994) Prey selection by the scyphomedusan predator Aurelia aurita. Mar Biol 121:335-341

Sullivan BK, Suchman CL, Costello JH (1997) Mechanics of prey selection by ephyrae of the scyphomedusa Aurelia aurita. Mar Biol 130:213-222

Taghon GL, Nowell ARM, Jumars PA (1980) Induction of suspension feeding in spionid polychaetes by high particulate fluxes. Science 210:562-564

Thomassen S, Riisgård HU (1995) Growth and energetics of the sponge Halichondria panicea. Mar Ecol Prog Ser 128: 239-246

Tiselius P (1989) Contribution of aloricate ciliates to the diet of Acartia clausi and Centrophages hamatus in coastal waters. Mar Ecol Prog Ser 56:49-56

Trager G, Genin A (1993) Flow velocity induces a switch from active to passive suspension feeding in a porcelain crab Petrolisthes leptocheles (Heller). Biol Bull 185:20-27

Trager GC, Hwang JS, Strickler JR (1990) Barnacle suspension-feeding in variable flow. Mar Biol 105:117-127

Trager G, Coughlin C, Genin D, Achituv A, Gangopadhyay Y (1992) Foraging to the rhythm of ocean waves: porcelain crabs and barnacles synchronize motions with flow oscillations. J Exp Mar Biol Ecol 164:73-86

Vahl O (1973) Efficiency of particle retention in Chlamys islandica (O.F. Müller). Astarte 6:21-25

Valdivia N, Stotz W (2006) Feeding behavior of the porcellanid crab Allopetrolisthes spinifrons, symbiont of the sea anemone Phymactis papillosa. J Crustac Biol 26:308-315 van Weel PB (1937) Die Ernährungsbiologie von Amphioxus lanceolatus. Pubbl Stn Zool Napoli 16:221-272

Vanderploeg HA (1994) Zooplankton particle selection and feeding mechanisms. In: Wotton RS (ed) The biology of particles in aquatic systems, 2nd edn. Lewis Publishers, Boca Raton, FL, p 205-234

Vedel A, Riisgård HU (1993) Filter-feeding in the polychaete Nereis diversicolor: growth and bioenergetics. Mar Ecol Prog Ser 100:145-152

> Vedel A, Andersen BB, Riisgård HU (1994) Field investigations of pumping activity of the facultatively filter-feeding polychaete Nereis diversicolor using an improved infrared phototransducer system. Mar Ecol Prog Ser 103:91-101

Vogel S (1994) Life in moving fluids. The physical biology of flow. Princeton University Press, Princeton, NJ

Waggett R, Costello JH (1999) Capture mechanisms used by the lobate ctenophore, Mnemiopsis leidyi, preying on the copepod Acartia tonsa. J Plankton Res 21:2037-2052

Waggett R, Sullivan LJ (2006) Feeding efficiency of the larval ctenophore Mnemiopsis leidyi A. Agassiz (Ctenophora, Lobata). J Plankton Res 28:719-723

Ward JE (1996) Biodynamics of suspension-feeding in adult bivalve molluscs: particle capture, processing, and fate. Invertebr Biol 115:218-231

Ward JE, Shumway SE (2004) Separating the grain from the chaff: particle selection in suspension- and deposit-feeding bivalves. J Exp Mar Biol Ecol 300:83-130

> Ward JE, Sanford LP, Newell RIE, MacDonald BA (1998) A new explanation of particle capture in suspension-feeding bivalve molluscs. Limnol Oceanogr 43:741-752

Ward JE, Sanford LP, Newell RIE, MacDonald BA (2000) The utility of in vivo observations for describing particle capture processes in suspension-feeding bivalve molluscs. Limnol Oceanogr 45:1203-1210

Watts E, Petri M (1981) A scanning electron microscope study of the thoracic appendages of Daphnia magna Straus. J Nat Hist 15:463-473

> Wells GP, Dales RP (1951) Spontaneous activity patterns in animal behaviour: the irrigation of the burrow in the polychaetes Chaetopterus variopedatus Renier and Nereis diversicolor O. F. Müller. J Mar Biol Assoc UK 29:661-680

Welsch U (1975) The fine structure of the pharynx, cyrtopodocytes and digestive caecum of amphioxus (Branchiostoma lanceolatum). Symp Zool Soc Lond 36:17-41

Werner B (1953) Über den Nahrungswerb der Calyptraeidae (Gastropoda Prosobranchia). Helgol Wiss Meeresunters 4: 260-313

> Werner B (1959) Das Prinzip des endlosen Schleimfilters beim Nahrungserwerb wirbelloser Meerestiere. Int Rev Hydrobiol 44:181-215

- Williams TA (2007) Structure and development of setae on the thoracic limbs of the anostracan crustacean, Thamnocephalus platyurus. Arthropod Struct Dev 36:63-76

Winston JE (1977) Feeding in marine bryozoans. In: Woollacott RM, Zimmer RL (eds) Biology of bryozoans. Academic Press, New York, NY, p 233-271

Winston JE (1978) Polypide morphology and feeding behavior in marine ectoprocts. Bull Mar Sci 28:1-31

Wotton RS (1994) Methods for capturing particles in benthic animals. In: Wotton RS (ed) The biology of particles in aquatic systems. Lewis Publishers, Boca Raton, FL, p 183-204

- Wyeth RC (1999) Video and electron microscopy of particle feeding in sandwich cultures of the hexactinellid sponge, Rhabdocalyptus dawsoni. Invertebr Biol 118:236-242

> Yahel G, Marie D, Beninger PG, Eckstein S, Genin A (2009) In situ evidence for pre-capture qualitative selection in the tropical bivalve Lithophaga simplex. Aquat Biol 6:235-246 